DOE/ER/13961--3

DE93 007692

\title{
EVAPORITES AS A SOURCE FOR OIL
}

PROGRESS REPORT

for Period November 15, 1988 - November 15, 1992

1B. C. SCHREIBER,1S. BENALIHIOULHAJ and 2R. P. PHILP

1DEPARTMENT OF GEOLOGY QUEENS COLLEGE

CITY UNIVERSITY OF NEW YORK

FLUSHING, NEW YORK 11367

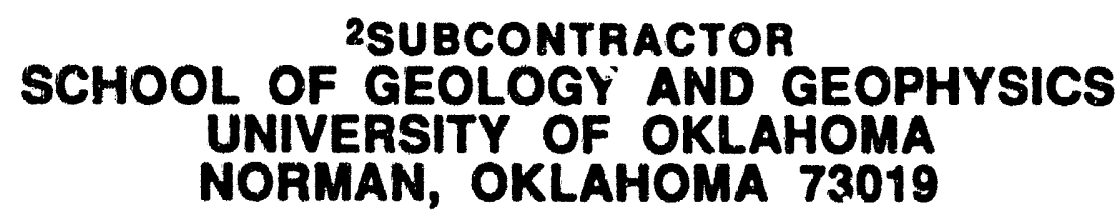

FEBRUARY, 1993

PREPARED FOR THE U.S. DEPARTMENT OF ENERGY AGREEMENT NO. DE FG02-88ER13961 


\section{NOTICE}

This report was prepared as an account of work sponsored by the United States Government. Neither the United States nor the Department of Energy, nor any of their employees, nor any of their contractors, subcontractors, or their employees, makes any warranty, express or implied, or assumes any legal liability or responsibility for the accuracy, completeness, or usefulness of any information, apparatus, product or process disclosed or represents that its use would not infringe privately-owned rights. 


\title{
ABSTRACT 1988-1992 REPORT EVAPORITES AS A SOURCE FOR OIL
}

\author{
B. C. SCHREIBER, S. BENALIIOULHAJ AND R.P. PHILP
}

Organic matter, present in some sediments, acts as the source for hydrocarbons and has been studied at great length, but organic-rich sediments from hypersaline environments are just beginning to be understood. Many types of organic matter from such restricted environments have been identified, and in this study their maturation pathways and products are being explored. By collecting biologically-identified organic matter produced within modern evaporative environments from a number of different marine and nonmarine settings and carrying out detailed geochemical examination of samples we are gradually beginning to understand these materials. The organic samples collected were from evaporative marine, sabkha, and lacustrine deposits, and have been subjected to two types of artificial maturation, hydrous and confined pyrolysis, over a fairly wide range of temperatures $\left(150^{\circ}\right.$ to $\left.350^{\circ} \mathrm{C}\right)$. The biomarker products of these treatments are being analyzed and followed in great detail. Analyses of saturate and aromatic hydrocarbons as well as sulfur compounds in the original and the matured samples provide a comprehensive view of the biomarker assemblages associated with these different depositional environments at different stages of maturity. Infrared spectroscopy and Rock Eval pyrolysis of both the isolated kerogens from both the original and pyrolyzed samples has permitted us to clearly characterize the functional groupings on the one hand and the free hydrocarbons, the potential hydrocarbons, and the oxygenated compounds on the other hand. We have thus been able to demonstrate the potential of the organic matter associated with the different evaporitic environments to act as a good source for oil generation.

Comparable ancient sediments that are organic-rich, and that have achieved various degrees of maturity, have also been sampled and analyses are being run on the biomarkers present in these samples and in the hydrocarbons that they have produced. By using what we and others are learning of environmental controls on organic production in the modern settings, and following the evolution of these compounds during maturation we are now becoming able to examine ancient organic-rich rocks and to understand the details of the components that went into their formation. 


\section{EVAPORITES AS A SOURCE FOR OIL}

\section{INTRODUCTION}

\section{A. Relationships in time and space}

Review of the geological record clearly demonstrates a spatial and temporal relationship between evaporites and oil and/or organic-rich sequences. This is not to say that evaporative conditions are required to produce organic-rich sequences, but that there is a marked positive correlation that has brought us into this investigation. The literature contains numerous references to such evaporite/hydrocarbon relationships (in review, Evans and Kirkland, 1988), but the observations that evoked this particular study exist in the Messinian evaporites of Sicily where there are numerous sulfur mines, ranging all across the island, in which oil seeps are ubiquitous. The mines commonly contained large pools of very immature, asphaltic oil, all of approximately the same composition, that is apparently seeping out of Messinian sediments despite the fact that they overly very diverse strata, ranging in age from Triassic to Middle Miocene. Because these Messinian sediments are largely immature, it was assumed that the oil seeps came from the older underlying rocks. But if this diversity of source was true, why are these oils all (1) highly immature and (2) everywhere of the same composition? It was this observation that triggered our study.

As a first part of the investigation of this enigmatic relationship, we undertook an examination of the evaporative sections as seen in the immature Messinian sediments of the Mediterranean. It showed us that while the thick halite and much of the gypsum in the section contains a very low organic content $(<1 \%)$, the intercalated marls, limestones and shales (also all formed in very restricted environments) may contain as much as $25 \%$ TOC. The organic-rich intercalations, however, contain few if any evident fossils and normally have been described as "barren" despite their high organic content. Where does this organic matter originate and why so few shells, burrows and other traces of life forms? In order to understand this paradox, it became clear that diverse, modern, evaporative environments must be examined, and the organic matter typified.

\section{B. Environments of Deposition}

Evaporites form in marine, marine-marginal (mixed water) and continental settings. They all share the following characteristics: 


\section{b.1. High productivity}

Observation of modern marine salinas, sabkhas and saline playas reveals high levels of biological productivity. The first phases of concentrative activity result in a restricted fauna and flora but with prolific numbers of individuals. Influx of either marine and/or continental waters provides additional nutrient levels. The population of flora and fauna provides food for an additional, seasonal, influx of birds and other animals together with fecal input, that adds to the nutrient input. As the ponds and playas become more saline the biotic diversity decreases even further (only with cyanobacteria, halophylic bacteria, brine shrimp, air-breathing gastropods and some annelids) but the nutrient input from the precedent population seems to carry through and the water is teeming with life. Wading birds continue to visit these ponds for parts of each day to feed on the masses of bacteria and they also find safety for their eggs and young on the islands within the ponds. Predatory snakes and mammals rarely enter these pond areas because of the resulting irritation to their bodies so that the eggs and young of the birds are safely isolated. The water of the ponds is green to pink in color (depending on which bacteria are present) and contains so much suspended organic matter that it resembles a thick soup. A rain storm (dilution) or desiccation (concentration) causes the death of the current population and the development of a thin layer of organic matter on the floor of the pond. As conditions return to the original levels of flooding and salinity, the flora and fauna proliferate once again.

\section{b.2. High salinity, density, temperature, water stratification and restricted oxygen exchange}

Elevated salinities have other effects besides those directly affecting biological diversity and productivity. Saline water becomes more and more dense as salinity rises, and this also raises the viscosity of the water, causing limited mixing and increasing stratification. Increasing salinity also causes a marked decrease in the rate of evaporation such that at salinities somewhat above halite saturation, evaporation ceases entirely unless the relative humidity of the air is exceedingly low $(25-30 \%)$. However, in fact, the evaporative process continues even with humidities up to $65 \%$. This occurs because the temperature of the pond water rises and is often above $50^{\circ} \mathrm{C}$. Why does this heating take place?

The increased density of the saline water causes a greater degree of refraction of the entering light from the sun (especially affecting the infrared radiation) which traps the incoming energy and results in rising water temperatures (up to $45^{\circ} \mathrm{C}$ ). 
The higher salinity and temperatures are also conducivo to the preferential growth of halophyllic bacteria that contain red chlorophyll, which in turn refracts the entering infrared rays even further. The increasing heat content does not readily escape the pond waters, particulary because they have become more and more strongly stratified, and the average water temperature in summer may rise to $55^{\circ} \mathrm{C}$ (well above ambient air temperatures). In fact it can even rise to over $60^{\circ} \mathrm{C}$, but at those temperatures the halophyllic bacteria begin to die and the red color disappears-so the temperature drops back to $45^{\circ}-50^{\circ} \mathrm{C}$. At water temperatures of $50-55^{\circ} \mathrm{C}$ the rate of evaporation remains relatively rapid up to near the concentrations required for potassic and magnesian salts (at $50-65 \%$ rel. humidity) but concentration rarely reaches saturation levels because this highly mineralized water is exceedingly hygroscopic (requiring $<25 \%$ rel. humidity). These highly mineralized waters are very viscous and remain stratified even when only a few tens of centimeters deep, preventing contact of less-saline, oxygenated water with the underlying bottom sediments.

At elevated salinities and temperatures gases such as $\mathrm{O}_{2}$ and $\mathrm{CO}_{2}$ are only slightly soluble in water. This results in non-oxygenated bottom water and/or sediments. Even when very shallow (a few centimenters) the diffusion of air (or any gas) into the saline water column is essentially nil. As a result, the organic matter that is produced in the upper (less saline) part of a stratified column sinks to the bottom during periods of reduced stratification and is then removed from both bacterial and atmospheric degradation. Anaerobic bacteria, that could possibly act within these bottom sediments, produce $\mathrm{H}_{2} \mathrm{~S}$ as a byproduct of their life processes, but this gas is trapped within the sediments for most of the year - as long as the water is very saline. The excess $\mathrm{H}_{2} \mathrm{~S}$ inhibits the further activity of the anaerobes, and this also preserves the organic-rich sediments. Overlying deposits of gypsum and/or halite commonly form an excellent, air-tight seal, even after deposition has ceased.

In summary: high salinities produce a high level of biological productivity. The product of this productivity is preserved by (1) high density water layers; (2) low levels of oxygen exchange; (3) low levels of anaerobic activity; and(4) overlying mineral seals.

\section{Purpose of Study}

Accepting the fact that evaporative environments both produce and preserve organic matter we have set out to fullill the following lines of study: 
1. To characterize (chemically) organic matter taken from a wide range of organicrich evaporative settings.

2. To study, using both sedimentology and geochemistry, the evaporative facies containing organic-rich sequences.

3. Characterization of oils related to source-rocks from evaporative systems.

\section{SAMPLES STUDIED}

Samples we employ are taken from numerous modern and ancient settings representative of many different environments of deposition (see below). These samples have been examined using many different techniques, listed and described in chapter III (below), and the samples and the types of analyses are listed in Table 1 ( $A$ and $B$ ). These include modern sediments, immature sediments, mature sediments and evaporite-related oils.

\section{A. Evaporative source-rocks}

Samples of potential evaporative source-rocks have been taken (Figure II.1) from the Mediterranean area (Miocene), the Bresse Basin of France (EoceneOligocene), and more recently several suitable samples have been obtained from the Michigan Basin (Silurian, mid-continent USA). These samples are all evaporative intercalations (calcareous shales and gypsiferous limestones) and are generally representative of the appropriate "source rock" types associated with evaporites. All of these samples come from within evaporite sections and are usually barren of normal fossil assemblages, except for stromatolitic structures, some pollen, 1 or 2 species of coccoliths, and euryhaline diatoms (all restricted by geologic time as well as sample content). Without extensive microscope study, many of these samples would be termed "barren", except for their high TOC.

In the Michigan basin there are three cores presently available that are located just downdip from the three oil samples that we have obtained. The evaporative shales and limestones within these sections are composed of high TOC materials, and we are sampling tinem in order to compare source/oil relationships. 
Evaporites as a source

Rock for Petroleum

DOE Funded Project

C.U.N.Y.

Geology + Sedimentology

+ stratigraphy
0.0 .

organic Geochemistry

\section{Research approaches}

Modern analogs for geological models.
Immature organicrich sequences within evaporitic deposits
011 s related to evaporitic sources
Marine: Santa pola

Marine Mixed: S, Margherita

Non marine: Petrola, Quero

Tirez, saladar

Marine Sabkha: Arabian Gulf
Lorca Basin Morico Basin Laga Basin Bresse Basin Gibelilina paradox basin Arab "D" Formation Egyptian oil Seep $011 \mathrm{~s}$ from Sicily
GC

GC-MS

Confined Pyrolysis

Hydrous Pyrolysis

Elemental Analysis

Infrared spectroscopy
Stratigraphy

sedimentology

organic Petrography

GC

GC-MS

GC-MS-MS

PY-GC
GC

GC-MS

GC-MS-MS

Figure 1.1. Diagrammatic representation of research approaches and materials used in these studies. 


\begin{tabular}{|c|c|c|c|c|c|c|c|c|c|c|c|c|c|c|c|}
\hline SAMPLE OAKOIN & EXT. & FRA & H.P. & G.P. & CCP & $\cos$ & $\operatorname{aca}$ & acnc & $\operatorname{cost}$ & ocus & HPLC & C13 & Toc & R-E & EM \\
\hline $\begin{array}{l}\text { Santa Pola } \\
\text { (o- Spain) }\end{array}$ & 36 & 38 & 3 & 17 & 20 & 23 & 23 & 8 & 8 & 80 & 2 & 37 & 30 & 25 & 10 \\
\hline $\begin{array}{l}\text { Palrola } \\
\text { (Epain) }\end{array}$ & 17 & 13 & 7 & 8 & 3 & 13 & 13 & 2 & 2 & 10 & 2 & 13 & 13 & 17 & 7 \\
\hline $\begin{array}{l}\text { Saladar } \\
\text { (Spaln) }\end{array}$ & 7 & 7 & 3 & 4 & 2 & 4 & 4 & & & 2 & 1 & & 4 & 8 & 1 \\
\hline $\begin{array}{l}\text { Ounero } \\
\text { (Spain) }\end{array}$ & 6 & e & 4 & & 2 & 5 & $\mathbf{s}$ & 1 & 1 & 10 & & 10 & 5 & 5 & 1 \\
\hline $\begin{array}{l}\text { Trez } \\
\text { (Speln) }\end{array}$ & 4 & 4 & 3 & & 2 & 4 & 4 & 1 & 1 & 3 & 1 & 11 & 4 & 4 & 1 \\
\hline A Cuantir & 4 & 4 & 2 & & & 4 & 4 & & & 6 & & 2 & 2 & & 5 \\
\hline
\end{tabular}

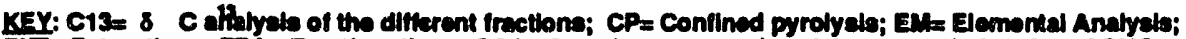

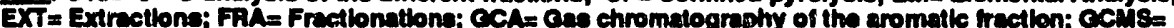

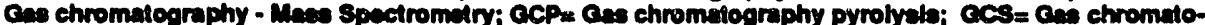
Craphy of the seturated traction; CCST= Cas chromatography of tho uterols; HP= Hydrous pyrolycla; H.P.L.C.= High preasure liquid chrematography; RE= Rock. Eval pyrolyele; T.O.C.= Tolal organle carbon.

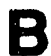

\begin{tabular}{|c|c|c|c|c|c|c|c|c|c|}
\hline SAMPLE OALIN & EXT & FRA & $\cos$ & $\operatorname{coc} A$ & PYA & acus & PYA & C13 & TOC \\
\hline $\begin{array}{l}\text { Lorea } \\
\text { (Spaln) }\end{array}$ & 25 & 11 & 11 & 11 & 2 & 22 & & 21 & 25 \\
\hline$\underset{\text { San Martino }}{\text { Spin) }}$ & 1 & & & & & & & & \\
\hline $\begin{array}{l}\text { Banihujar } \\
\text { (Spaln) }\end{array}$ & 1 & & & & & & & & \\
\hline $\begin{array}{l}\text { Loga Bagln } \\
\text { (N. Maly) }\end{array}$ & 4 & 4 & 4 & 4 & 4 & $B$ & & 11 & \\
\hline $\begin{array}{l}\text { Olbeilin } \\
\text { Pletly }\end{array}$ & 1 & 1 & 1 & 1 & 1 & & & 1 & \\
\hline $\begin{array}{c}\text { Fiume salso } \\
\text { (Sleily) }\end{array}$ & 1 & 1 & 1 & & & 2 & 1 & 3 & \\
\hline $\begin{array}{l}\text { Roalmonte MIno } \\
\text { (SIclly) }\end{array}$ & 1 & 1 & 1 & 1 & & 2 & & 2 & \\
\hline $\begin{array}{l}\text { Arecen Bagln } \\
\text { (Franco) }\end{array}$ & 24 & 23 & 16 & 6 & 1 & 16 & 23 & 10 & \\
\hline
\end{tabular}

KEY: EXTx Extrectiona; FFA= Frectionations; CCS= Qas chromatography of the eaturated traction;

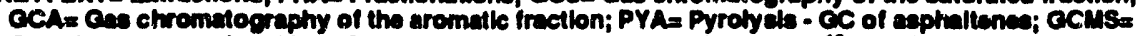

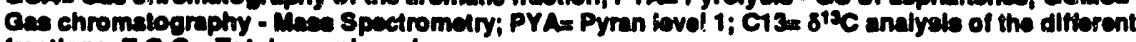
Iractions; T.O.C.= Total organic carbon.

Table 1. Summary of analyses run on samples from immature orgaric-rich sequences within evaporitic deposits. (A) present data on analyses run to date on modern sediments; (B) represents analyses run on evaporative source-rock samples pertormed to date. 


\section{B. Samples from Recent evaporative environments.}

\section{b.1 Santa Pola}

Modern, solar salt works are evaporitive environments in which large volumes of organic matter are formed and preserved along with the various mineral deposits. The salina at Santa Pola, located in S-E Spain (Figure II.1), is a marine-fed lake that has a rich and distinct faunal and floral association and produces a discrete set of characteristic litho-, chemico- and biofacies. The main domains characteristlc of evaporative environments are well repesented in this salina, and a set of samples representative of these three domains was collected by hand-coring sediments from Santa Poia in water that was $10-20 \mathrm{~cm}$ depth.

\section{b.2. Al Qanatir}

Organic-rich sediments formed within sabkha-like environ nents (marine marginal setting) are not uncommon in association with some source rock sections. Samples representative of the sabkha deposits studied in this project were collected by coring from the region of Al Qanatir in the Arabian Gulf (Figure II.2). These samples originated in portions of the sabkha affected largely by marine waters and much of the organic matter originates in the intertidal to supratidal zone. This organic matter, once buried, remains as an algal peat in the subsurface.

\section{b.3. La Manchia}

We have chosen to study several continental saline lakes (Petrola and Saladar) and playas (Tirez and Quero) from the region of La Manchia, Spain (Figures II.1 and II.3). The samples were obtained using box-corers and/or spades from the floor of the playas and lakes. These lakes have developed in a very arid region in which most of the water is present only in the subsurface and much of the mlneral content comes from solution of the underlying Triassic ard Tertiary evaporite deposits. The extremly elevated salinities in the groundwater and the lakes, however, arise because of high rates of evaporitive concentration, with an average of $400 \mathrm{~mm}$ rainfall per year but over $1000 \mathrm{~mm}$ of evaporation per year. The various lakes in the eastern and western portions of La Manchia differ in average water composition. The organic content and compositions of the lakes vary greatly, probably to a large measure depending on the degree of desiccation reached each summer and the length of time the lake-bottom sediments remain exposed and become oxygenated. 


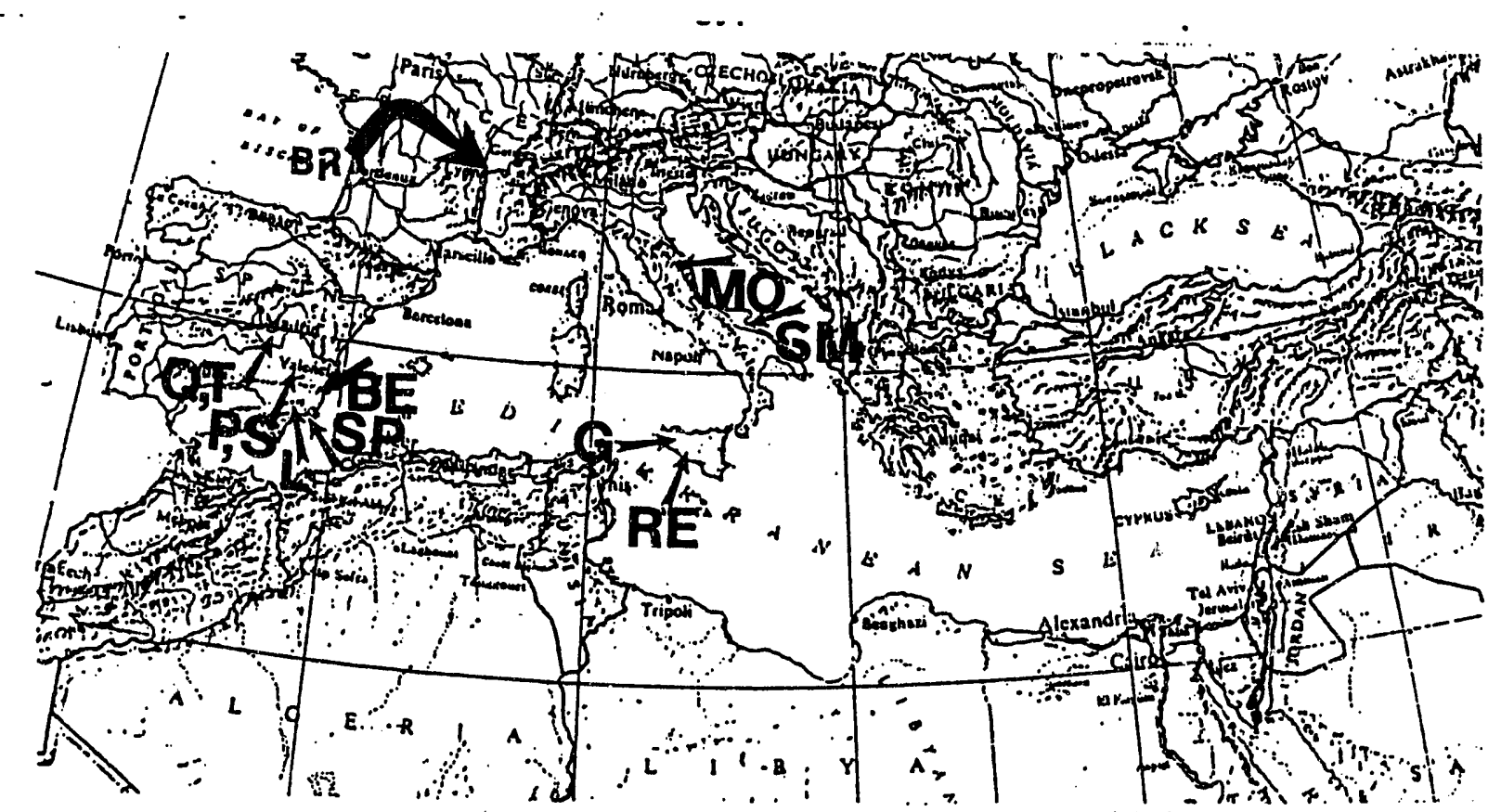

Figurell,1. Map of the Mediterranean area showing collection sites of both Messinian and modern evaporative sediments. KEY: Marine ponds: SP = Santa Pola (salina near Alicante, Spain); SM = Marghenita di Savoia (salina near Bari, Italian Adriatic). Lakes (non-marine): la Manchia (central Spain), western section (near Toledo), $T=$ Tirez; $Q=$ Quero); eastern section (near Albacete), $P=$ Petrola; $S=$ Saladar. Geological sectlons: se Spain, $L=$ Lorca; $B E=$ Benejuzar. Italy; Sicily, GIB = Gibeilina; RE = Realmonte; Italy; Apennines, $M O=$ Morico. 


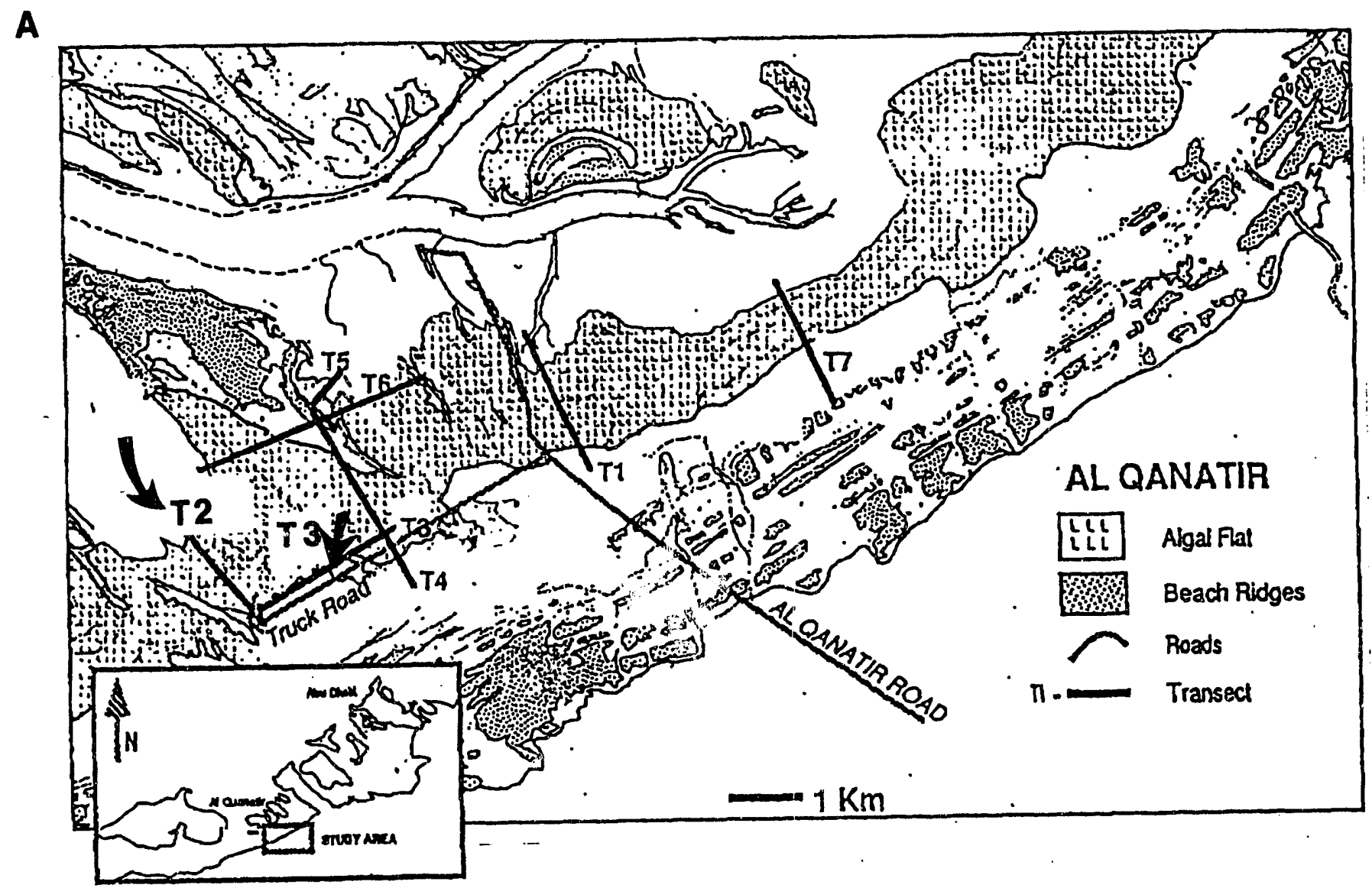

Figure II.2. (A) Map view of the Al Qanatir sabka region along the south side of the Arabian Gulf (Persian Gulf) showing sampled sections (maps and samples courtesy Dr. A. Cohen, U. South Carolina). N.B. Transect sections T2 and T3; (B) Cross-section shows profile position of sample T2-5, analyzed in this study; (C) Cross-section shows profile position of sample T3-15, analyzed in this study. 
B

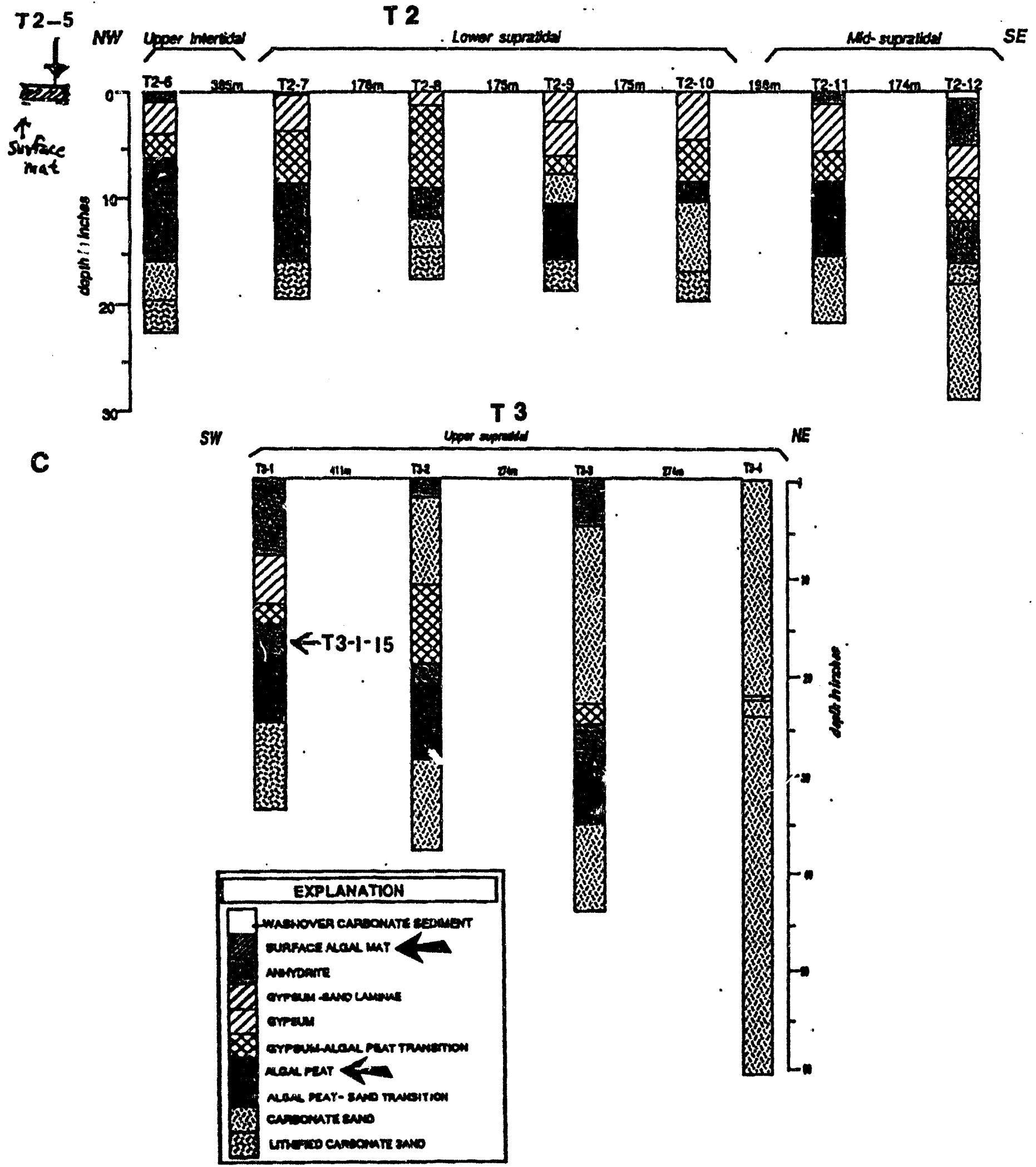




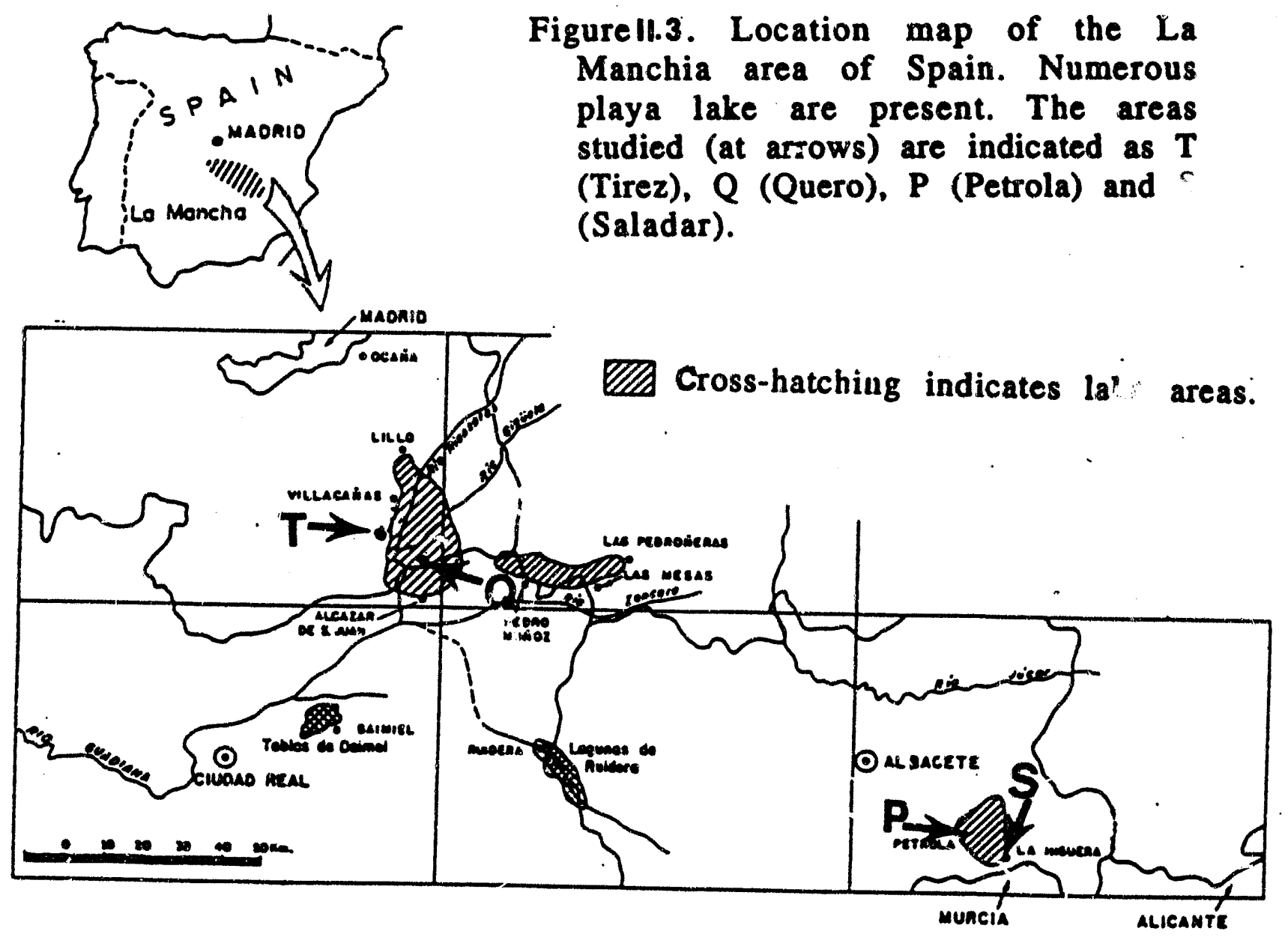




\section{Olls related to evaporative systems}

The following oils known to be related to evaporitic systems have been collected and are in the process of being analysed:

- 17 oil samples from Pripiat basin in Russia.

- 3 Oil sampless from the Michigan basin.

- 1 Oil from Egypt.

- 1 Oil semple from Saudi Arabia.

- 1 Oii i ingle from Sicily.

\section{EXPERIMENTAL PROCEDURES.}

A. Organic carbon: Total organic carbon determinations of the samples were made using a LECO carbon analayser.

8. Kerogen isolation: This process was carried out on the original and the artificlally matured samples by demineralization of the samples using $\mathrm{HF}$ and $\mathrm{HCl}$ according to techniques outlined by Durand (1980). This process isolates the kerogen quantitatively without noticable alteration its general structure.

C. Rock-Eval pyrolysis: Rock-Eval pyrolysis (Espitalié et al., 1977) was carried out on the original and the artificially matured sediments. This process allows quantitative analysis of the hydrocarbon compounds and the oxygenated compounds that are present atter pyrolysis of a sample at $55 \mathrm{u}^{\circ} \mathrm{C} .\left(@ 25^{\circ} \mathrm{C} / \mathrm{min}\right)$ in an inert atmosphere. The peaks that are obtained from this analysis yield information concerning: free hydrocarbons, potential hydrocarbons and oxygenated compounds.

D. Elemental analysis: Quantification of the amounts of $C, H, O, N$ and $S$ present in the isolated kerogen from the original and the pyrolysed samples permits the determination of the atomic composition of the organic matter.

E. Gas chromatography: After removal of the asphaltenes from the extract by npentane precipitation, the extract was fractionated into saturated, aromatic and polar fractions. Saturated and aromatic fractions were analyzed by gas chromatography using either a HP5890 or a Varian 3300 instrument. Both instruments were equipped with a $\mathrm{J}$ and $\mathrm{W}$ Scientific DB-5 fused silica capillary 
column and helium was used as carrier gas. Oven temperature was programmed from $40^{\circ} \mathrm{C}$ to $130^{\circ} \mathrm{C}$ at $15^{\circ} \mathrm{C} / \mathrm{min}$ and then to $300^{\circ} \mathrm{C}$ at $4^{\circ} \mathrm{C} / \mathrm{min}$ and held isothermally for 25 minutes.

e. Gas chromatography coupled with mass spectrometry: Mass spectrometry was performed using a Finnigan MAT triple-stage quadrupole mass spectrometer (TSQ 70). A Varian gas chromatograph equipped with DB-5 fused silica capillary column was interfaced to the msss spectrometer. Both simple-ion monitoring (SIM) and multiple-ion (MID) techniques were used. For GC-MS/MS analysis the mass spectrometer was operated in parent (PAR) mode.

F. Stable isotope determinations: $1 \mathrm{mg}$ of sample is combusted at $550^{\circ} \mathrm{C}$ for 3 hours in a pyrex tube. After the tube was cracked on the vacuum rack in a tube cracker, the sample was purified cyogenically and then transferred directly into the mass spectrometer (Finnigan MAT Delta E Isotope Ratio Mass Spectrometer). $\delta^{13}$ was calculated by the standard definition at the $\delta^{13}$ value with respect to the PDB international reference standard.

G. Hydrous pyrolysis: The sample was placed in stainless steel tube and distilled water added to cover the sample. The tube was heated for a period of 72 hours at subcritical water temperatures (less than $374^{\circ} \mathrm{C}$ : Lewan, 1985). The temperatures used in our experiments are: $280^{\circ} \mathrm{C}, 310^{\circ} \mathrm{C}, 330^{\circ} \mathrm{C}, 350^{\circ} \mathrm{C}$ and $365^{\circ} \mathrm{C}$.

H. Confined pyriolysis: About 2 grams of a powdered sample was placed in a small, thin-walled gold tube which was flushed with argon and seal od (with an argon atmosphere) and placed into an autoclave equipped to exert and maintain an hydrostatic pressure of 1 kilobar. Each sample was in a separate tube. The samples were heated at the rate of $25^{\circ} \mathrm{C} / \mathrm{min}$ to the desired temperature and held there for 24 hours. The pyrolysis temperatures used were: $200^{\circ} \mathrm{C}, 250^{\circ} \mathrm{C}, 300^{\circ} \mathrm{C}$, $350^{\circ} \mathrm{C}$ and $400^{\circ} \mathrm{C}$ (Monthioux ot al., 1985; Monthioux ot al., 1986).

\section{RELATIONSHIP OF ORGANIC GEOCHEMISTRY TO SEDIMENTATION UNDER HIGHLY VARIABLE ENVIRONMENTS, LORCA BASIN (SPAIN): PRELIMINARY RESULTS}

\section{A. INTRODUCTION}

Immature organic rich sequences in evaporitic systems contain biomarkers which have fingerprints characteristic of the original biomass and/or the environmental 
conditions prevailing at the time of deposition. In many cases interpretations based on the hydrocarbon distributions may be difficult because of the alterations occurring during the diagenesis of the organic matter. Because geologists employ the paradigm that the present is the key to the past, modern evaporitic environments have been used to obtain a better understanding of the processes leading to the accumulation and preservation of organic matter in evaporitic systems (Waples and others 1974: Philp and others, 1978; Philp, 1980; Albaiges and others, 1984; Rowland and others, 1985; Jiamo and others, 1986; Volkman, and others, 1986; Kenig and others, 1990; Barbe and others, 1990; Wakeham and others, 1990). Despite the efforts of the last ten years towards the identification of organic compounds present in recent evaporitic environments, there is still relatively little data which establishes direct links between the micro-organisms and the biomarkers encountered in the different facigs of evaporites. On the contrary, geochemical techniques traditionally applied to the study of the organic geochemistry of petroleum and ancient sediments, are more frequently employed in studying the microbiology and biogeochemistry of saline lakes with high biological activity (Javor, 1989).

The work described herein is an attempt to further our understanding of the association between organic matter and evaporites. The regulating factors of this association are not always woll established and the alteration of the organic matter in the depositional environment and during its sedimentary evolution only complicates the situation. The case of pristane and $p$ :ytane is important from this point of view. A wide range of examples discussing the of these compounds and the validity of the use of the relative $\mathrm{Pr} / \mathrm{Ph}$ ratio as an indicator of depositional conditions in terms of Eh and salinity exists in the literature (Brooks and others, 1969; Powell and McKirdy 1973; Didyk and others, 1978; Risatti and others, 1984; Goosens and others, 1984; Volkman and Maxwell 1986; ten Haven and others, 1985; Moldowan and others, 1986; ten Haven and others, 1987; ten Haven and others, 1988; Freeman and others, 1989; Freeman and others, 1990; de Leeuw and Sinninghe Damste 1990).

The study of biomarkers in the Lorca Basin sediments further illustrates the complexity surrounding the pristane and phytane distribution. It has been shown that four organo-facies can be distinguished in the stratigraphic section of the basin on the basis of lithological and sedimentiological characteristics, and saturated hydrocarbon distributions (notably $\mathrm{C}_{22}, \mathrm{Pr}$ and $\mathrm{Ph}$ ). In this paper it is proposed to discuss these organo-sedimentary variations in order to reconstruct the depositional history of the variations of the Lorca Basin. 


\section{B. GeOlogical SETting}

The earliest Tertiary deposition within the area of the Lorca basin began toward the upper Lower Miocene and sporadically continued until the Serravallian (Middle Miocene), but most of this section is either covereri or has been removed by erosion, with the exception of a few patches present around the periphery of the basin (Figure IV.1). After a phase of regional tectonism due to strong changes in plate motion (Dewey and others, 1989), deposition during the lower part of the Upper Miocene began with shallow-water marine to estuarine deposits atop a tilted and truncated Middle Miocene (Serravalian) section and passes upward into the largely open-marine, Upper Miocene section (Tortonian-Messinian) (Figure IV.2). Most of this Upper Miocerie sequence is composed of fossiliferous, calcareous to siliciclastic turbidites interlayered with calcareous hemipelagic marine marls. In this section, however, there is evidence of sporadic periods of restricted circulation within the basin. These restricted phases are represented by thin diatomites apparently formed during stratification of the water. Stratification produced a depositional sequence composed of finely laminar diatomite/coccolith oozes (marine species with a low diversity) that originated from high productivity in the photic zone within a basin that had a poorly oxygenated to anoxic bottom. These biogenic sediments are largely laminar, unburrowed, with no benthonic faunal remains and presently have little or no organic content (on outcrop). Many of the diatomites within the lower part of the section are silicified to chert. In most examples the diatomites throughout the column are directly overlain by fossiliferous marls that indicate a return to normal, open-conditions with good bottom circulation (diverse benthonic foraminiferal population).

In several parts of the sequence the layers of diatomite are much thicker, relatively unaltered and some are overlain by exceptionally organic-rich, laminar, calcareous, pelitic shales (TOC >25\%). A few of the diatomite-shale pairs are overlain by somewhat sandy, porous, unfossiliferous limestones with numerous lenticular to nodular vugs, sporadically filled with sulfur, that have a lower organic content than the underlying shales (TOC <2\%). In thin section, it is evident that in the limestone some of the pore-filling cement is gypsum together with a coarse calcite mosaic, and that the voids are relics of lenticular, rosette and nodular displacive gypsum (formed from evaporative waters, within soft sediments). This specific change in the style of sedimentation, with the grouping of diatomites, organic-rich shales and gypsiferous limestone, was probably produced by varying degrees of basinal restriction and stratification that took place sporadically during the deposition of the sequence. The most restricted component, the gypsiferous limestone, was formed only five times in the entire sequence. After each restriction the basin returned to open marine conditions, but circulation became increasingly limited upsection. 


\section{GENERAL GEOLOGICAL MAP OF LORCA AREA}

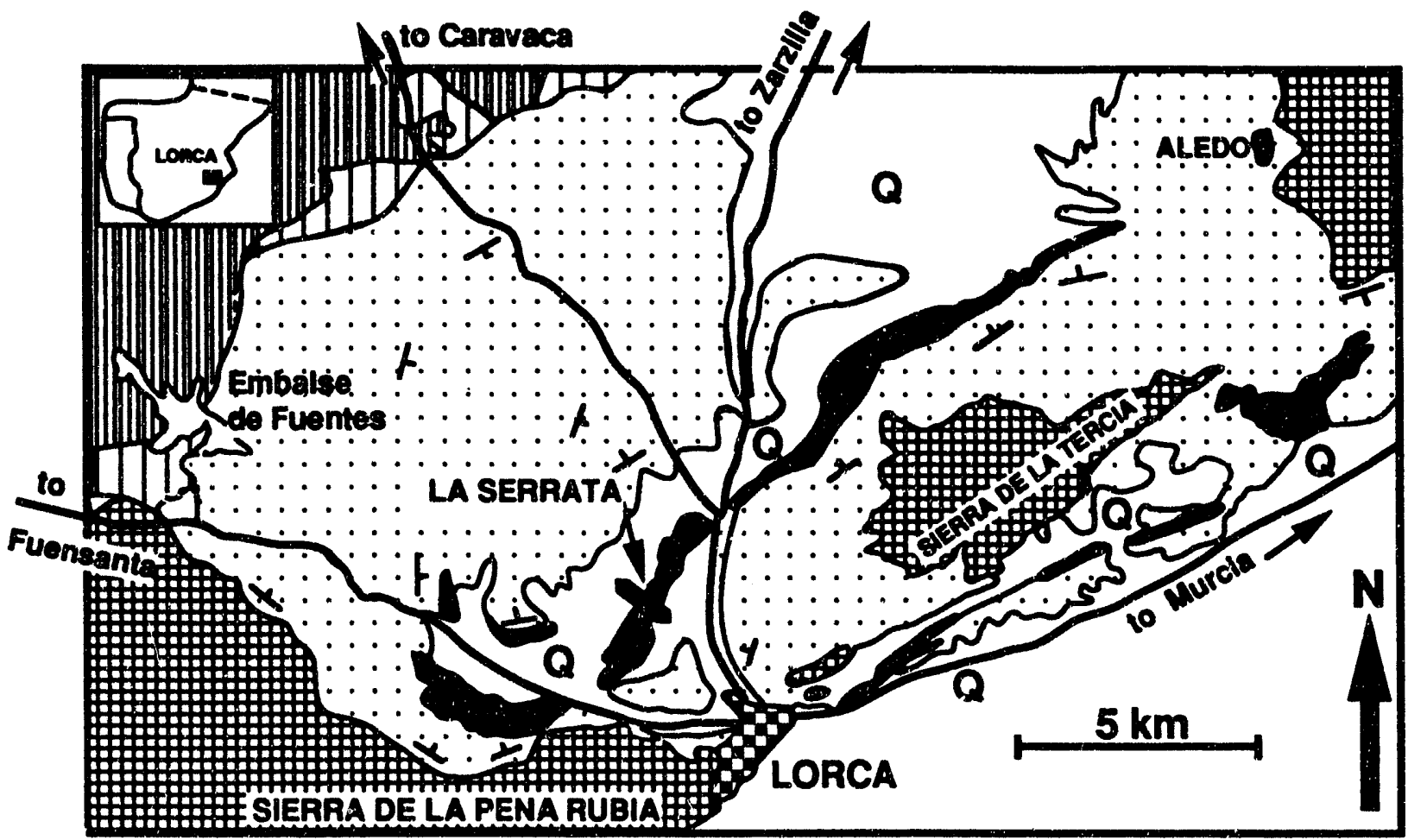

IFGMND

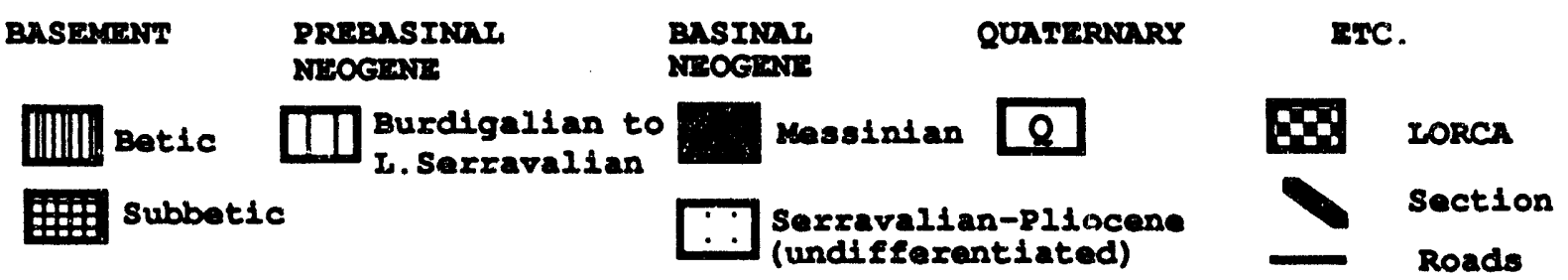

Figure IV.1. Geological map of the region near Lorca, southeastern Spain. Inset shows location map. Adapted from Geel (1976/1978). 
The uppermost part of the section at Lorca is the product of a period of marked restriction in circulation, during which the sporadic influx of continental (meteoric) water became increasingly important. The tangible effects of continental water input toward the top of the section is expressed sedimentologically by the accumulation of several massive beds of unfossiliferous sandstone (tidal to fluvial) containing several thin intercalations of dark-colored, clayey mudstone with well-preserved land plant remains (TOC $=0.31 \%$ ) (Figure IV.2, indicated by *). The outright establishment of evaporative conditions with massive deposition of gypsum and halite only took place during the Latest Miocene (Upper Messinian) as seen in the upper part of the exposed sections and in boreholes (Orti, 1990). Based on the morphology of the gypsum and halite, under these extreme evaporative conditions, deposition took place within very shallow water, and preservation of organic matter was reduced. The evaporites themselves contain little organic residue (TOC $<0.46 \%$ ). Stable isotope studies of this gypsum ( $\delta^{34} S$ and $\delta^{18} 0$ ) by Pierre (1982) and Utrilla (1989) strongly suggest that the gypsum section formed from mixed waters (highly evaporated marine to continental). The bromine profile from the basin-center halite section (boreholes) also demonstrates an increasing proportion of continental water (Veigas and others, 1990) and suggests that the basin had become a saline lake toward the top of the section.

\section{BIOMARKERS}

Evaporite environments are sites of elevated biological activity, but despite the fact that conditions are very favorable for the formation, accumulation and the conservation of organic matter, these sediments have rarely been the object of organic geochemical studies to determine the signatures of their biological precursors and diagenetic evolution (ct. Busson, 1979; Rouchy, 1982; Eugster, 1985, Warren, 1986; Evans and Kirkland, 1988; Hite and Anders, 1991). Organic compounds or lipids can be extracted from these sediments through treatment by organic solvents such as dichloromethane. Biomarkers are compounds, generally hydrocarbons, present in geological samples whose structures can be related to functionalized precursor molecules occurring in living systems (Philp and Lewis, 1987). Identification of the biomarkers permits the establishment of the origin or evolution of organic matter from which they originated, together with inferences concerning the depositional environments and extent of the diagenesis of this organic matter. A number of studies concerned with biomarker distributions in carbonate and evaporite environments have been reported in the literature (ten Haven and others, 1985; Connan and others, 1986; ten Haven and others, 1988; de Leeuw and Sinninghe Damste, 1990). In order to understand the origin of various biomarkers in diverse sediments, we have undertaken a study of the hydrocarbons contained in the lipid extract of the organic matter associated 


\section{GENERAIIZED STRATIGRAPHIC SECTION OF IORCA BASIN: MIOCENE SECTION AS MEASURED ON THE IA SERRATA RIDGE}

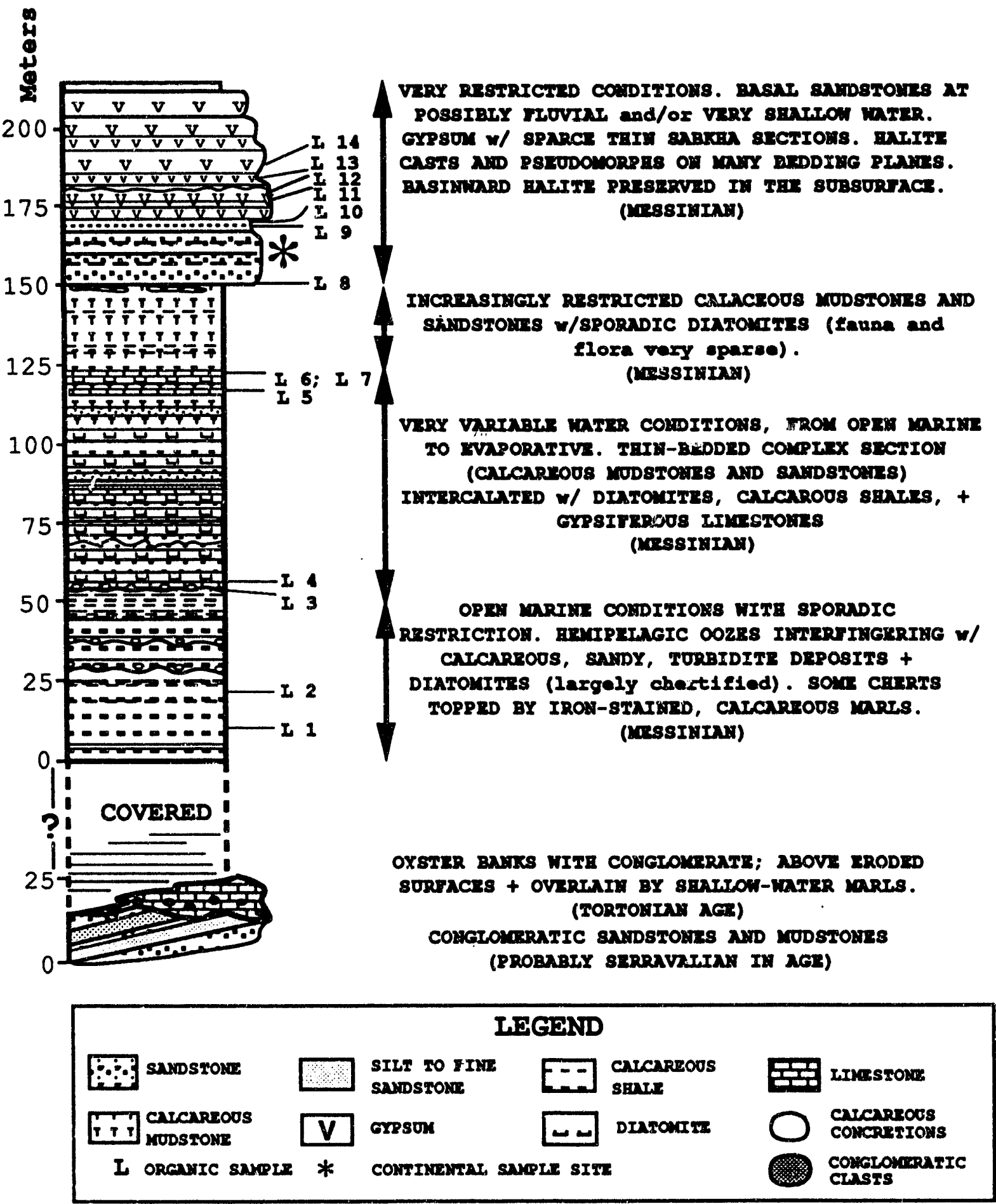

Figure IV.2. Stratigraphic section of the "La Serrata" section (outcrop), Lorca basin, southeastern Spain. Note that lower part of the column is taken from a site $1 \mathrm{~km}$ from the Serrata and is incomplete because the section is partially covered by Pleistocene-Recent sands and soils. Age designation for the "Serravalian" (Middle Miocene) sandstones and mudstones is poorly constrained because of a paucity of fossils, and may in fact be Lower Tortonian. 
with the diverse sedimentary facies encountered in the Lorca Basin and then discuss them based on the analyses of their n-alkanes and isoprenoid distributions.

\section{Experimental Procedure:}

Sampling:

The samples examined in this study were collected from fourteen levels in the La Serrata section that were chosen as representative of diverse lithologies of the sedimentary facies present in the exposed Messinian section of the Lorca basin (Figures IV.1 and IV.2 for sample location, depths, sedimentology and general mineralogy).

Analytical techniques:

Total organic carbon (TOC) determinations of the samples were made using a LECO carbon analyser CR-12. The samples were extracted with a mixture of dichloromethane and methanol (9:1) in a Soxhlet apparatus. After the removal of asphaltene from the extract by $\mathrm{n}$-pentane precipitation, the extract was fractionated into saturate, aromatic and polar fractions with thin layer chromatography (TLC: silica gel plates $-0.25 \mathrm{~mm}$ thickness). The saturate fraction was analyzed by gas chromatography using a Varian 3300GC and G/C conditions include: spitless injection system; injection temperature of $300^{\circ} \mathrm{C}$; oven temperature programmed from $40^{\circ} \mathrm{C}$ to $130^{\circ} \mathrm{C}$ at $15^{\circ} \mathrm{C} / \mathrm{min}$, to $300^{\circ} \mathrm{C}$ at $4^{\circ} \mathrm{C} / \mathrm{min}$, and held isothermally for $25 \mathrm{~min}$. The instrument was equipped with DB-5 fused-silica capillary column $(30 \mathrm{~m} \times 0.25 \mathrm{~mm})$ and helium was used as the carrier gas at a flow rate of $1 \mathrm{ml} / \mathrm{min}$.

\section{RESULTS AND DISCUSSION}

\section{Quantitative evaluation of the different fractions from lipid extacts:}

The relative proportions of extractable organic matter (EOM) relative to the total organic carbor, and the amount of sample extracted are given in Table IV.1. These values vary from 5.45 to $28.57 \%$ and from 3.92 to $9.02 \%$, respectively. The values for TOC and EOM were quite variable, possibly due to the diversity of the original carbon input into the Lorca basin and/or the variability of the physio-chemical depositional and diagenetic conditions, but there is a good correlation between the amount of EOM and TOC values. Such a correlation is characteristic of the presence of immature organic matter in the sediments (Tissot and Welte, 1984). The proportions of the different fractions relative to the quantity of the lipid extract (Table IV.1) emphasize the relatively high concentrations of polar compounds $(64-92 \%)$ in all samples which is also characteristic of immature organic matter (Tissot and Welte, 1984). The relative 
TABIE 1.

\begin{tabular}{|c|c|c|c|c|c|c|c|c|c|c|}
\hline \multirow{2}{*}{ SAMPLE } & \multirow{2}{*}{ zonganic } & \multicolumn{2}{|c|}{ MPID EXTRACT } & \multirow{2}{*}{$\begin{array}{l}\text { SATUNATES } \\
\text { roth Exrenet } \\
\end{array}$} & \multirow{2}{*}{$\begin{array}{l}\text { Anomarics } \\
\text { a rotme surecert }\end{array}$} & \multirow{2}{*}{$\begin{array}{c}\text { POLARS } \\
\text { D rota Expect }\end{array}$} & \multirow{2}{*}{ Pr/Ph } & \multirow{2}{*}{ Pr/nC } & \multirow{2}{*}{$P_{h} / \mathrm{nC}_{1 \mathrm{~s}}$} & \multirow{2}{*}{$R_{22}=\frac{\mathrm{CC}_{2}}{\mathrm{C}_{21} \cdot \mathrm{C}_{23}}$} \\
\hline & & 8 nock & - oroamL & & & & & & & \\
\hline$t-1$ & 1.00 & 0.15 & 7.00 & $\mathbf{3 . 4}$ & 4.4 & e2. 2 & 0.64 & $\mathbf{0 . 5 2}$ & 0.90 & 1.08 \\
\hline L-2 & e0. 10 & $\cdots$ & $\cdots$ & $\cdots$ & $\cdots--$ & -... & $\cdots$ & $\cdots$ &.-- & $\ldots$ \\
\hline$L-3$ & 0.93 & 0.03 & 5.48 & s.3 & 4.3 & 90.2 & 0.72 & 0.41 & 1.90 & 5.70 \\
\hline $2-4$ & 1.20 & 0.00 & 7.50 & 2.8 & 10.8 & $\bullet .0$ & 0.54 & 0.50 & 2.69 & 2.70 \\
\hline$L-3$ & $\mathbf{2 3 . 0 2}$ & 2.86 & 10.23 & 1.4 & 13.3 & 05.8 & 6. 15 & o.ez & 7.84 & 4.70 \\
\hline L-e & 27.75 & $3 . \bullet 2$ & 14.13 & 1.5 & 10.2 & 06.3 & 0.12 & 0.00 & 18.66 & 6.50 \\
\hline$L-7$ & 0.35 & 0.03 & 14.80 & 4.4 & 7.2 & 71.1 & 0.73 & 0.44 & 0.54 & 3.03 \\
\hline L-O & 0.31 & 0.04 & 12.00 & 96.3 & 2.6 & 64.0 & 1.50 & 0.73 & 0.84 & 1.45 \\
\hline$L-D$ & 0.21 & 0.08 & 26.57 & 31.3 & 4.6 & 12.0 & $\ldots$ & & $\cdots$ & $\cdots$ \\
\hline$L-10$ & 0.32 & 0.03 & 0.60 & 14.1 & 3.0 & 90.0 & 1.10 & 0.40 & 0.00 & 3.00 \\
\hline $\mid-11$ & 0.30 & 0.02 & 0.33 & 2.3 & 5.7 & 0.3 & 0.06 & 0.50 & 2.40 & 1.01 \\
\hline $1-12$ & 0.40 & 0.04 & 0.26 & 7.2 & 4.4 & $\cdots$ & 0.71 & 0.70 & 4.00 & 2.50 \\
\hline$L-13$ & 0.10 & $\cdots$ & $\cdots$ & $\cdots$ & $\cdots$ & $\cdots$ & $\ldots$ & $\cdots$ & $\ldots$ & $\ldots$ \\
\hline $2-14$ & $<0.10$ & $\ldots$ & $\ldots$ & $\cdots$ & $-\infty$ & $\ldots$ & $\ldots$ & $\infty \ldots$ & $\ldots$ & $\ldots$ \\
\hline
\end{tabular}

- REPRESEKTS VALUES tOO LOY TO DE MEASURED

Table IV.1. Summary of quantitative data obtained from the 14 extracts from the Lorca Basin. 
proportions of aromatic hydrocarbons varies from 2.6 to $13.3 \%$ and predominate over those of the saturate hydrocarbons which vary from 1.4 to $31.4 \%$, characteristic of samples having a marine origin (Tissot and Welte, 1984). Samples L-8, L-9 and L-10 differ from the other samples examined on basis of their relatively high concentration of non-aromatic hydrocarbons; $26.3,31.4$ and $14.1 \%$ respectively. The n-alkane distributions of these samples are also dominated by hydrocarbons of continental origin whereas all the other samples examined have a n-alkane distribution characteristic of organic matter derived mainly from marine material with a minor continental influence.

Saturate hydrocarbons :The distribution of the $\mathrm{n}$-alkanes and the ratios of $\mathrm{Pr} / \mathrm{Ph}$ and $R_{22}=2 C_{22} /\left(C_{21}+C_{23}\right)$ permit the samples examined in this study to be divided into distinct types that correspond with four lithologic groupings, and reflect the differences in the origin of the organic matter and the conditions of its deposition (Figures IV.3A and IV.3B).

Class 1. This type is represented by the organic-rich, calcareous, pelitic shale of samples L-5 and L- 6 whose $n$-alkanes are characterized by a bimodal distribution ranging from $n-C_{15}$ to $n-C_{35}$, with $n-C_{22}$ and $n-C_{31}$ as maxima and phytane is the most abundant component in the chromatograms (Figure IV.3A). The strong odd/even predominance of the components, greater than 23 , indicates the immaturity of the organic matter as well as the higher plant inpur into the organic matter (Table IV.1). The pristane/phytane ratio ( $\mathrm{Pr} / \mathrm{Ph}$ ) is very low (less than 0.15 ) and, based on the traditionai interpretation for this ratio, would suggest reducing conditions of deposition (Powell and McKirdy, 1973; Didyk and ozhers, 1978) which is also indicated by the very high amount of organic carbon (greater than $25 \%$ ). However care needs to be taken in interpreting $\mathrm{Pr} / \mathrm{Ph}$ ratios in extreme environments because it has been shown that phytane has a number of other origins such as archaeobacteria containing bisphytanyl ethers rather than chlorophyll (ton Haven and others, 1988; de Leeuw and Sinninghe Damste, 1990). Freeman (1989) has also demonstrated different sources for $\mathrm{Pr}$ and $\mathrm{Ph}$ based on isotopic measurements. Low $\mathrm{Pr} / \mathrm{Ph}$ ratios have also been found in organic matter from other evaporitive sequences (ten Haver and others, 1985; ten Haven and others, 1988; de Leeuw and Sinninghe Damste, 1990, Hite and Anders, 1991).

The ratios of $\mathrm{Pr} / \mathrm{n}-\mathrm{C}_{17}$ and particularly the high $\mathrm{Ph} / \mathrm{n}-\mathrm{C}_{18}$ values of 7.94 and 16.66 (Table IV.1) for the L-5 and L-6 samples respectively, can be considered to be a consequence of the high pristane and phytane content for these two samples plus their low levels of maturity. The predominance of $n-C_{22}$ has been interpreted as a 


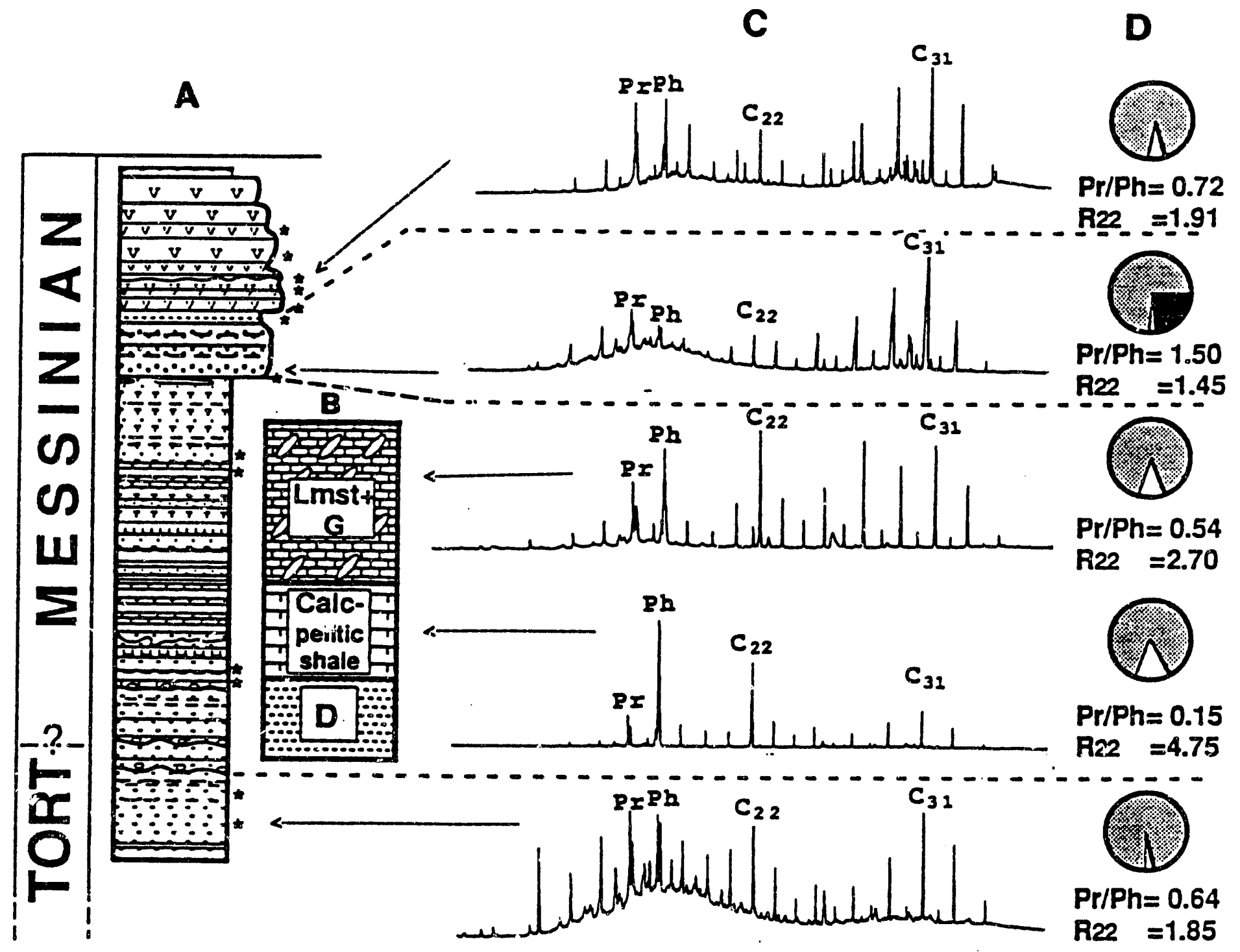

圈 POLARS $\square$ AROMATICS SATURATES

Figure IV.3. Correlation between lithology and biomarkers in the upper section of the Lorca basin. Column " $B$ " represents one of many short periods of extreme restriction within generally open conditions. The basin becomes totally continental just below the gypsum (note changes in gas chromatograms column " $C^{\text {" }}$ and changes in values given in column " $\mathrm{D}$ "), and then is of a mixed water origin within the gypsum itself. 
marker for hypersaline environments (ten Haven and others, 1988). Thierefore the high values of the $R_{22}=2 C_{22} /\left(C_{21}+C_{23}\right)$ index (Tables IV.1 and IV.2) also suggest a hypersaline environment for these two samples (4.78 for L-5 and 6.50 for L-6) although care must be taken in the case of samples with low TOC and EOM because $\mathrm{n}-\mathrm{C}_{22}$ has also been found as a contaminant in plastic containers.

Class II. Samples L-1, L-3, L-4, L-7, L-II and L-12 represent the second sample class composed of gypsiferous limestones and gypsum, that are distinguished from those of Class I mainly by a higher Pr/Ph ratio, ranging between 0.54 and 0.73 , and a lower $R_{22}$ ranging between 1.85 and 5.70 (Tables IV.1 and IV.2).

The ratios $\mathrm{Pr} / \mathrm{n}-\mathrm{C}_{17}$ and $\mathrm{Ph} / \mathrm{n}-\mathrm{C}_{18}$ range between $0.41-0.59$ and $0.54-4.00$, respectively, and are lower than those of Class I (L-5 and L-6, Tables IV.1 and IV.2 and Figure IV.3A). This cannot be interpreted as a difference die to maturity alone, because the geothermal gradient was and is modest (based both on lack of thermally-controlled clay diagenesis within the section and on the maturity of the kerogen present in the sediment). The odd/even predominance of the components greater than $\dot{\nu}_{23}$, and the evaluation of the different fractions from the lipid extract all also indicate a low grade of maturity for all the samples. These differences in organic composition may be connected to the conditions of deposition and diagenesis as well as the possibility of chunges in source material leading to a lower input of archaebacteria thought to be responsible for higher phytane contents in Class 1 samples.

Class III. This third type of sample is represented by $L-10$, a layer of reworked clastic gypsum, and is characterized by a ratio $\mathrm{Pr} / \mathrm{Ph}=1.1$, reflecting oxidizing conditions in the environment (Tables IV.1 and IV.2, Figure IV.3B). However, the index of $\mathbf{R}_{\mathbf{2 2}}=\mathbf{3}$ still reflects hypersaline conditions. Compared to the samples from the two preceding types, L-10 has a distribution of $n$-alkanes that shows a greater contribution of organic matter from terrestrial origins which also correlates with the relatively high proportion of saturates, $14.1 \%$, in this sample.

Class IV. Two samples, of marly siltstones between terrestrial sandstones ( $L-8$ and L-9), represent this class with L-8 characterized by a high predominance of terrestrial organic matter, an n-alkane distribution of the sample L-9 (Figure IV.3B) which is unimodal $\left(\mathrm{n}-\mathrm{C}_{21}-\mathrm{n}-\mathrm{C}_{33}\right.$ ) and has a strong odd-even predominance. Such a distribution indicates an exclusively continental character for the organic matter and its low range of maturity as well. The alkanes and isoprenoids in the $n-C_{17}-n-C_{20}$ 


\begin{tabular}{|c|c|c|c|c|c|c|}
\hline$\frac{\pi}{200}$ & - ancenryc & $D=/ 8 \mathrm{~m}$ & $P x / a-G_{7}$ & $P h / a-C_{10}$ & $R_{2 a}=\frac{2 C_{n}}{C_{n 1}+C_{2 n}}$ & $\begin{array}{l}\text { conenire } \\
\text { emouerno }\end{array}$ \\
\hline 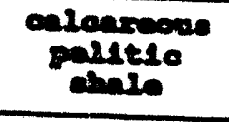 & $25-27.73$ & $\begin{array}{|ll|}.12 & -.15 \\
\end{array}$ & $.62-.60$ & $p .04-16.60$ & $4.70-7.94$ & crues I \\
\hline 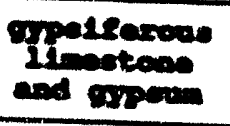 & $<.1-.35$ & $.54-.73$ & $.42-.32$ & $.54-4.0$ & $1.05-5.70$ & Crase II \\
\hline $\begin{array}{l}\text { alaotia } \\
\text { isperis }\end{array}$ & .32 & 1.2 & .49 & .60 & 3 & Cruse III \\
\hline $\begin{array}{c}\text { axty } \\
\text { altotion }\end{array}$ & .32 & 2.5 & .73 & .84 & 1.45 & crines IV \\
\hline
\end{tabular}

Table IV.2. The geochemical characteristics for the four classes of samples
discussed in this chapter. 
range are not detectable in sample L-9. Because much of any discussion concerning origin, deposition or diagenesis is based on the presence of pristane, phytanes or $\mathrm{n}$ alkanes, little further interpretation of this sample can be made. L-8 shows a high Pr/Ph ratio 1.5 and a relatively low $R_{22}$ ratio of 1.45 (Tables IV.1 and IV.2).

\section{INTERPRETATION}

The variations in the origin of organic matter as well as the conditions of its deposition are reflected in the great variability of the lithologies present in the stratigraphic section of the Lorca basin (Figure IV.2). The organo-chemical fluctuations observed in the $\mathrm{n}$-alkanes and isoprenoids illustrate the environmental groupings that originated under diverse depositional conditions in the same way as the sedimentological observations.

Calcareous pelitic shales represented by samples from Class I are characterized by elevated amounts of organic matter (TOC greater than 25\%). Tiieir sedimentological characteristics indicate deposition in a stratified body of water similar to the models described by Por (1972) and Busson (1978). Stratification within a such a water body resulted in restricted and highly saline bottom wateis for the basin where the calcareous, pelitic shales were deposited. This explains their exceptional richness in organic matter and the duality of having the greatest reducing and the highest salinity conditions in this class of organic facies. This interpretation also is supported by a study of the distribution of the biomarkers. The gypsiferous limestones of Class II, corresponds to the final phases of restriction leading to the formation of each of the repetitive organic-rich sequences that contain the calcareous pelitic shale. The physio-chemical conditions are indicated by the presence of gypsum that require neutral or oxidizing conditions that are necessary for the formation of gypsum and also allow for the efficient preservation of calcareous material (Busson, 1979). This is also supported by the highter Pr/Fh ratio and the lower $R_{22}$ ratio. The waters in which the limestones formed were relatively more oxidizing than those of the organic-rich shale just below.

The samples of Clais IV (L-8 and 9) that come from the marly siltstone facies (Figure IV.2) were formed under conditions associated with a high input of terrigenous material. This produced the development of strongly oxidizing conditions and the accumulation of organic matter from continental origin. The clastic gypsum lithology (Class III) that lies just above this continental sequence, was deposited from reworked and slightly earlier basinmargin gypsums. This episode is represented by samples from the upper section belonging to Class II and was deposited under intermediate Eh conditions between that of Class I on the one hand and Classes III and IV on the other hand. Based on the presence of terrestrial organic matter brought in during the deposition of the gypsum, continental influx was lower 
but was still effective. A reduction in both the marine and continental influx permitted an increasing concentration in the brines and led to formation of the evaporitic deposits that cap the section. In the areas that were studied, there was continuing but limited continental influx mixed with restricted amounts of marine water within the gypsum section that reflects the aridity of the basin and of the surrounding hinterlands. Based on sedimentological features, the gypsum deposits formed in fairly shallow waters with sporadic desiccation. At the basin center, in somewhat deeper water, there was halite sedimentation (Veigas and others, 1990).

The gypsum layers have almost no organic content, suggesting that rapid sedimentation under oxdizing to intermediate conditions allowed the formation of gypsum and were inhibiting factors for the incorporation and preservation of the organic matter. Comparable modern environments commonly have high organic productivity, but much of the organic matter is not preserved within the gypsum itself.

\section{E. CONCLUSIONS}

In summary, after a period of open marine circulation, characterized by the presence of turbidites and hemipelagic marls and the virtual absence of organic matter, periods of episodic restrictive conditions resulted in the stratification of the waisr body, and led to the formation of repetitive organic-rich sequences of diatomite - calcareous, pelitic shale and gypsiferous limestone. Near the top of the section the development of extreme restriction, associated with a strong continental input, resulted in the deposition of several continental beds topped by reworked gypsum. The persistence of marine restriction, associated with a depletion in the continental influx, then led to the concentration of the brines and formation of gypsum within the basin proper. The deposition of halite within intergypsum layers and at the basin center occurred from time to time due to nearly complete dryness, resulting from the aridity of the hinterland as well as a nearly total decoupling from marine influx. A projected paleo-reconstruction summarizing the different stages of the evolution of the Lorca basin water body, together with the sedimentation and the environmental interrelationships is shown in Figures IV.4 A and B. In general the increasingly restricted nature of the Lorca Basin is illustrated in Figure IV.4A. The environmental details of the evolution of the diatomite-shale-limestone sequences, the shales of which are exceedingly organic-rich (up to $25 \%$ TOC) is illustrated in Figure IV.4B. Based on our analysis, it is evident that during the Upper Miocene a gradual but episodic development of extreme basinal restriction governed sedimentation in the Lorca Basin and the nature of the organic matter and the overprints caused by the actual conditions of deposition as demonstrated by the saturated hydrocarbons have allowed us to follow evolution of the basin in parallel to changes in the sediments 
EYOLUTION OF LORCA BASIN TO PRODUCE INCREASINGLY RESTRICTED SEDIMENTATION

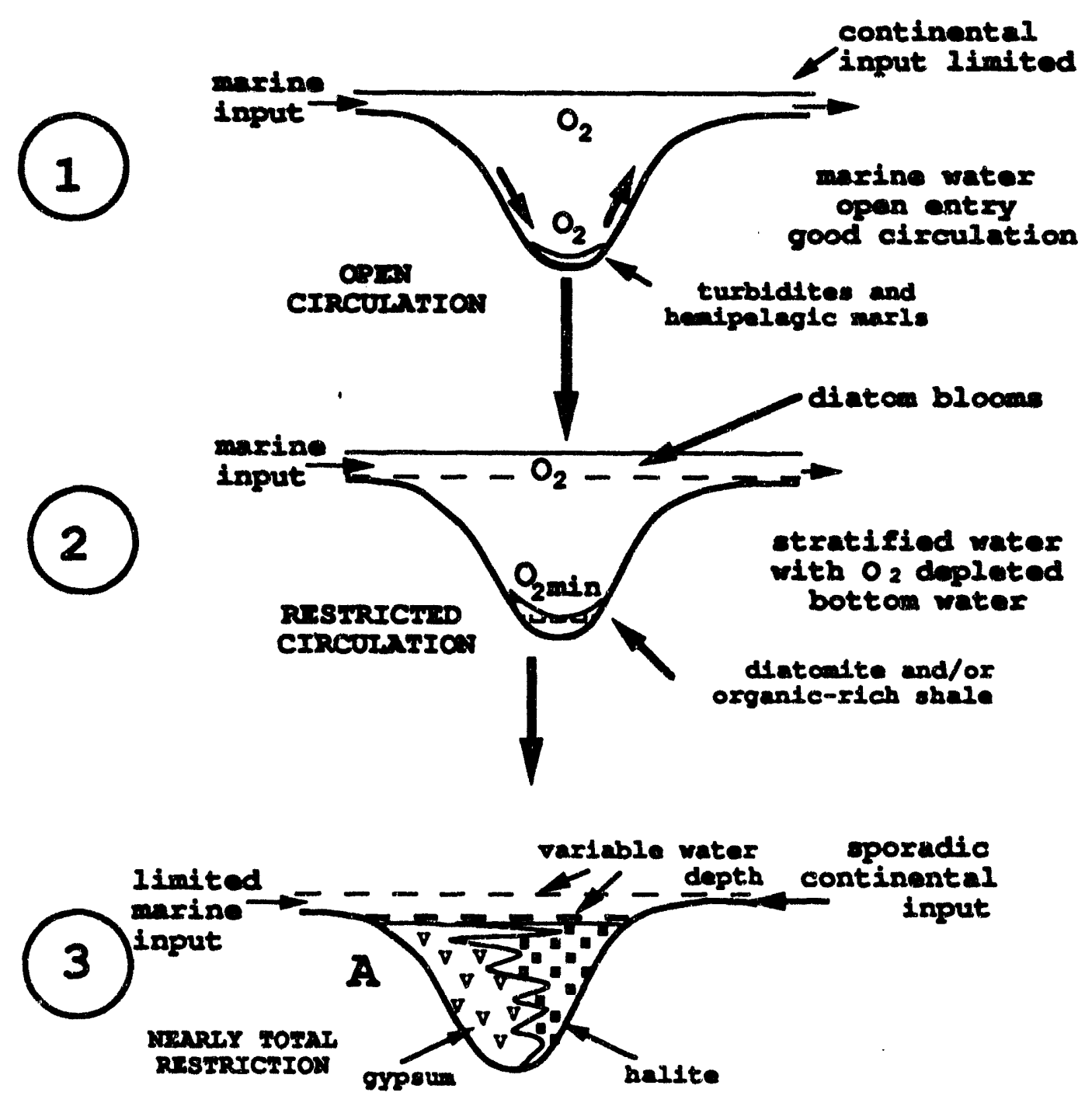

Figure IV.4. Diagrammatic representation of the evolution of the water and related sedimentation in the Lorca basin. A) General evolution going from open marine to diatomites-organic rich shales conditions related to restrictive phases, forming open-marine conditions. 
$\mathbf{B}$

\section{RESTRICTIVE EVOLUTION OF IORCA BASIN TO PRODUCE DIATOMITE-SBALE-LIMESTONE AND ASSOCIATED DIAGENESIS}

(1)

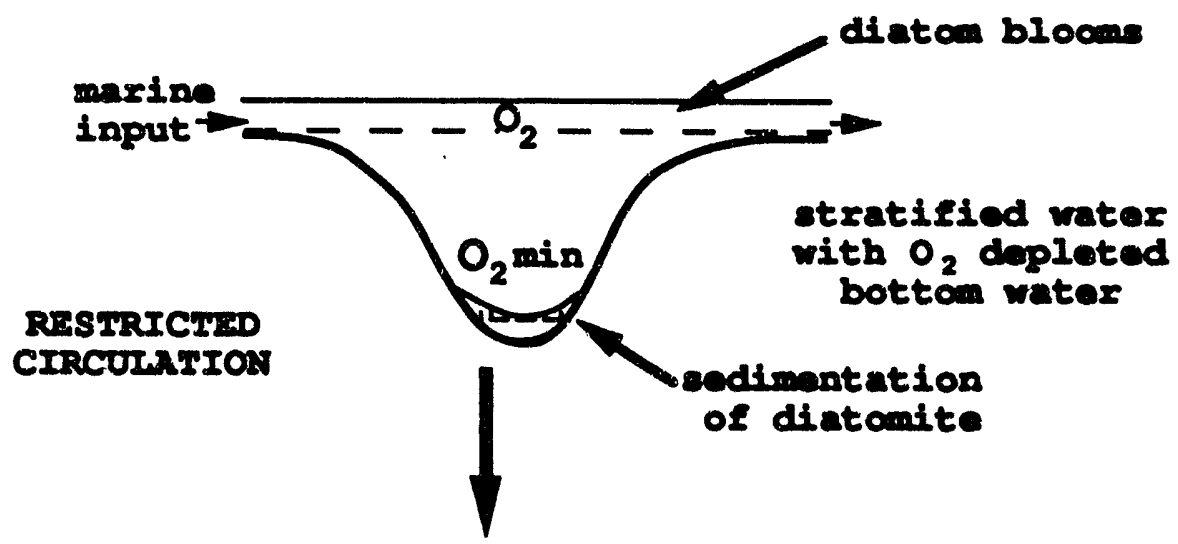

(2)

continental

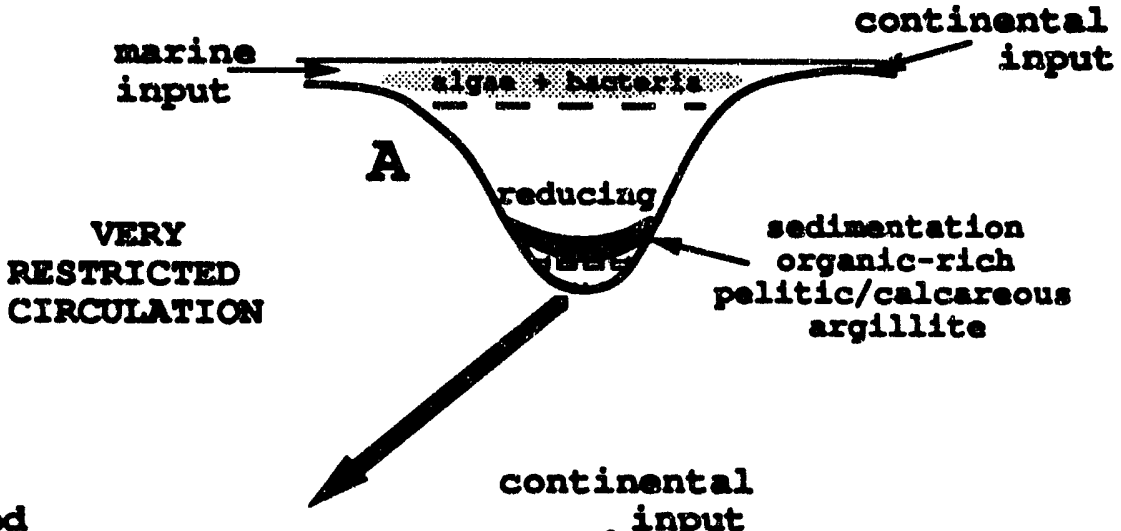
input

continental

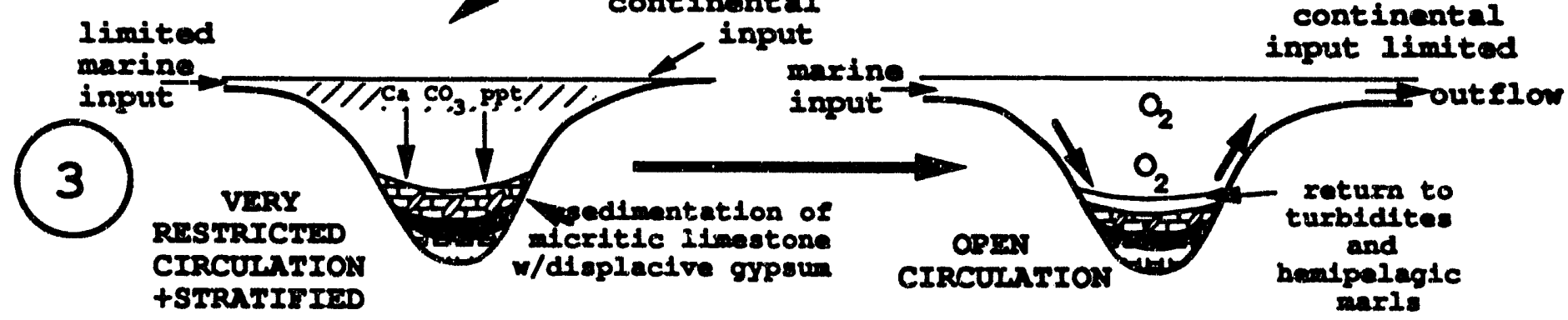




\section{CHARACTERIZATION OF ORGANIC MATTER FROM DIVERSE EVAPORITIC ENVIRONMENTS.}

\section{A. ELEMENTAL ANALYSIS AND ROCK-EVAL PYROLYSIS OF KEROGEN.}

Kerogen Is the organic matter which remains after the extraction of the sediments, using organic solvents (Durand, 1980). The method used for kerogen isolation is described above in chapter III (above). In order to globally characterize the organic matter associated with sediments from recent evaporative environments, which are our models for ancient geological analogs (i.e. marine evaporites, marine sabkha deposits and continental evaporites), the kerogen isolated from samples belonging to Santa Pola (marine), Al Qanatir (marine marginal), Petrola, Saladar, Tirez, and Quero (all 4 being continental) were studied using elemental analysis ( $C, H, N, O$ and $S$ ) and RockEval pyrolysis.

The values of $\mathrm{H} / \mathrm{C}$ and $\mathrm{O} / \mathrm{C}$ atomic ratios for the kerogens in this study vary from 1.03 to 1.67 and from 0.29 to 0.43 respectively (Figure V.I). Hydrogen Index and Oxygen Index values vary from 417 to 617 and 74 to 123 respectively (Figure V.2). The average values of $\mathrm{H} / \mathrm{C}(1.41)$ and Hydrogen Index (528) are relatively high and indicate that the kerogens are rich in hydrogen. Therefore, the organic matter associated with the sediments from the diverse evaporitic environments studied in this project might well provide a good source rock.

Samples from the continental lakes at Quero and Tirez distinguish themelves by the lowest values of $\mathrm{H} / \mathrm{C}$ atomic ratios and Hydrogen Index (Figures V.1 and V.2). This is probably due to the partial degradation of the organic matter after the desiccation of these playas during the dry season. It is in agreement with the low T.O.C. values $(<1$ $\%)$ observed in samples from these lakes.

Signlficant variations are observed for $\mathrm{S} / \mathrm{C}$ atomic ratios (0.008 to 0.036 ) (Figure V.3). The high amounts of sulfur in the kerogen, as high as $5 \%$, are probably due to the incorporation of sulfur by the organic matter after its depostion. This is confirmed by abundance of sulfur compounds in the extracts from the pyrolyzed sediments and kerogens. 


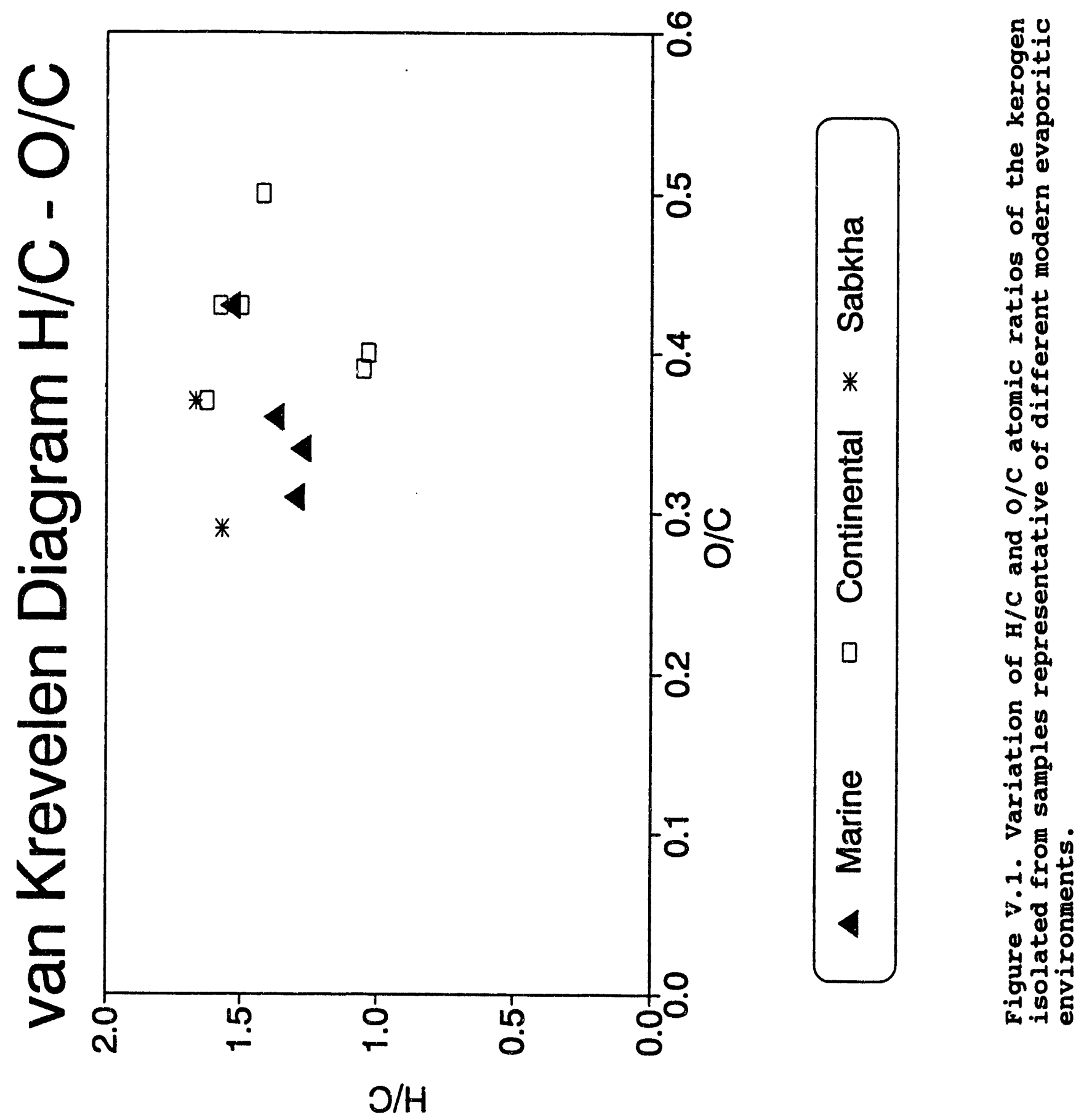


กิ
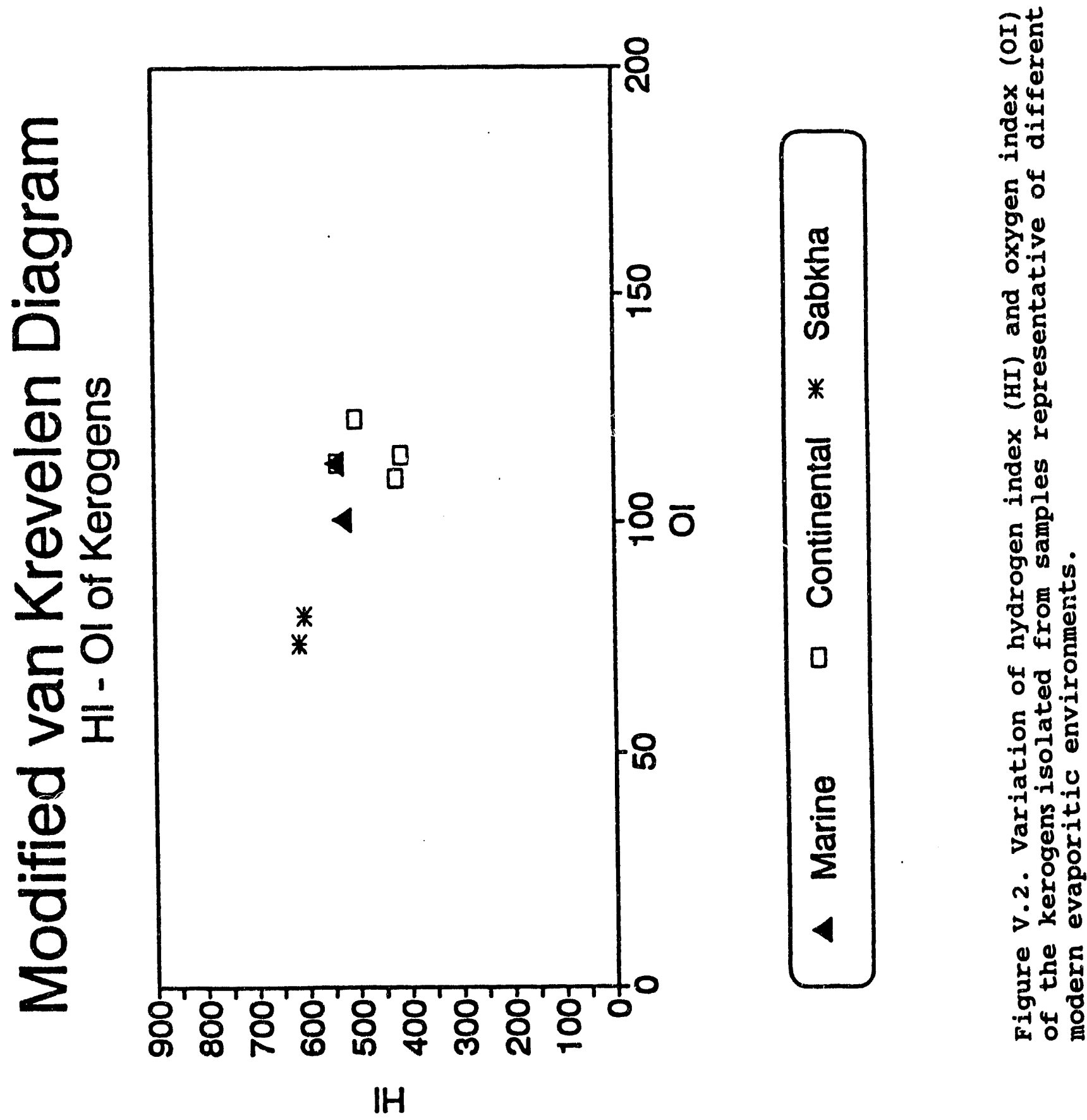

- 

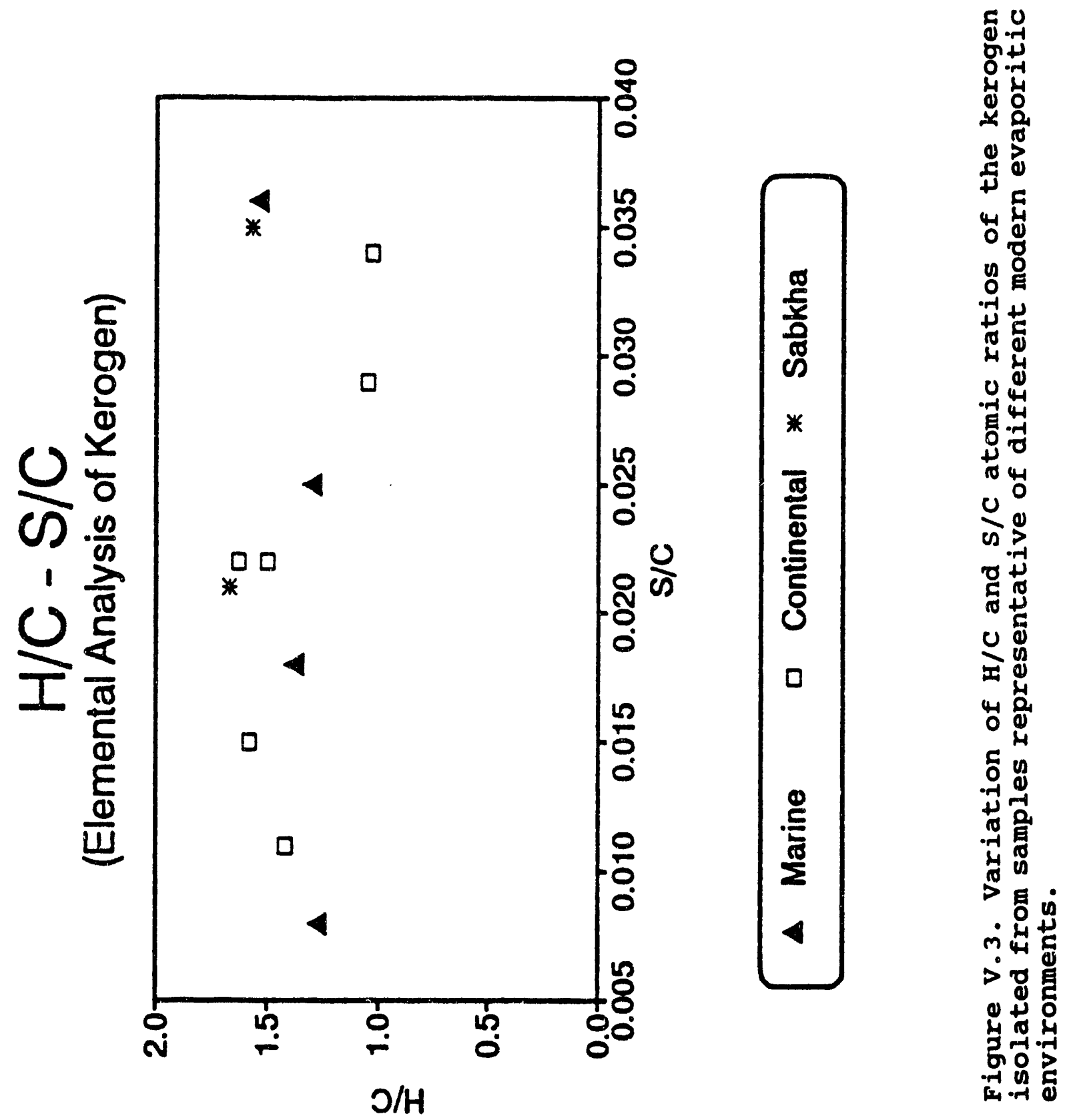


\section{B. SIMULATION OF OIL GENERATION IN EVAPORITIC SYSTEMS USING ARTLFICIAL MATURATION}

Recent evaporitic: environments offer good models for ancient evaporitic series which exist in the geological record. The study of the biomarkers present in their sediments may help to better characterize organic matter and oils related to evaporitic. systems. However, in recent sediments, most of the biomarkers exist as precursors and/or bound compounds in the structure of kerogen and the organic matter is still at a very immature stage. Any comparison or correlation $v$ ith oils and organic matter that have already undergone diagenesis is not only difficult but sometimes confusing and misleading. Thus artificial maturation experiments provide a comprehensive view of biomarker assemblages from recent evaporitic environments and provide an insight into their evolution with increasing maturity. Therefore, the comparison with oils and aricient sediments will be facilitated.

The simulation of oil generation using artificlal maturation is commonly used on ancient sediments. The most valid techniques used for this simulation are hydrous pyrolysis (Lewan, 1985) and confined pyrolysis, (Monthioux et al., 1985). Because we are studying recent sediments which have not yet undergone diagenesis, we employ both techniques in order to get as much information as possible on our simulation.

\section{Varlation of $H / C, O / C, N / C$ and $S / C$ atomic ratios with increasing} saturation temperatures.

Both hydrous and confined pyrolysis show a decrease in amounts of hydrogen and oxygen in the insoluble organic matter (kerogen) isolated from the pyrolysed samples with increasing temperature of pyrolyis, subsequently, a decrease in $\mathrm{H} / \mathrm{C}$ and $\mathrm{O} / \mathrm{C}$ atomic ratios takes place (Figure V.4). As with natural systems, this decrease expresses the loss in functionalized compounds and aromatization with the increasing maturity of the organic matter. At low temperatures of pyrolysis, the decrease in the N/C atomic ratio is probably due to the release of nitrogen rich compounds during maturation. The increase of the $\mathrm{S} / \mathrm{C}$ atomic ratio is more difficult to explain, probably due to the interaction between sulfur and the organic matter during the maturation experiments.

\section{Variation of the total extract with increasing maturation.}

The extractable organic matter from the original samples is dominated by polar compounds. The composition of the lipids released during maturation show 

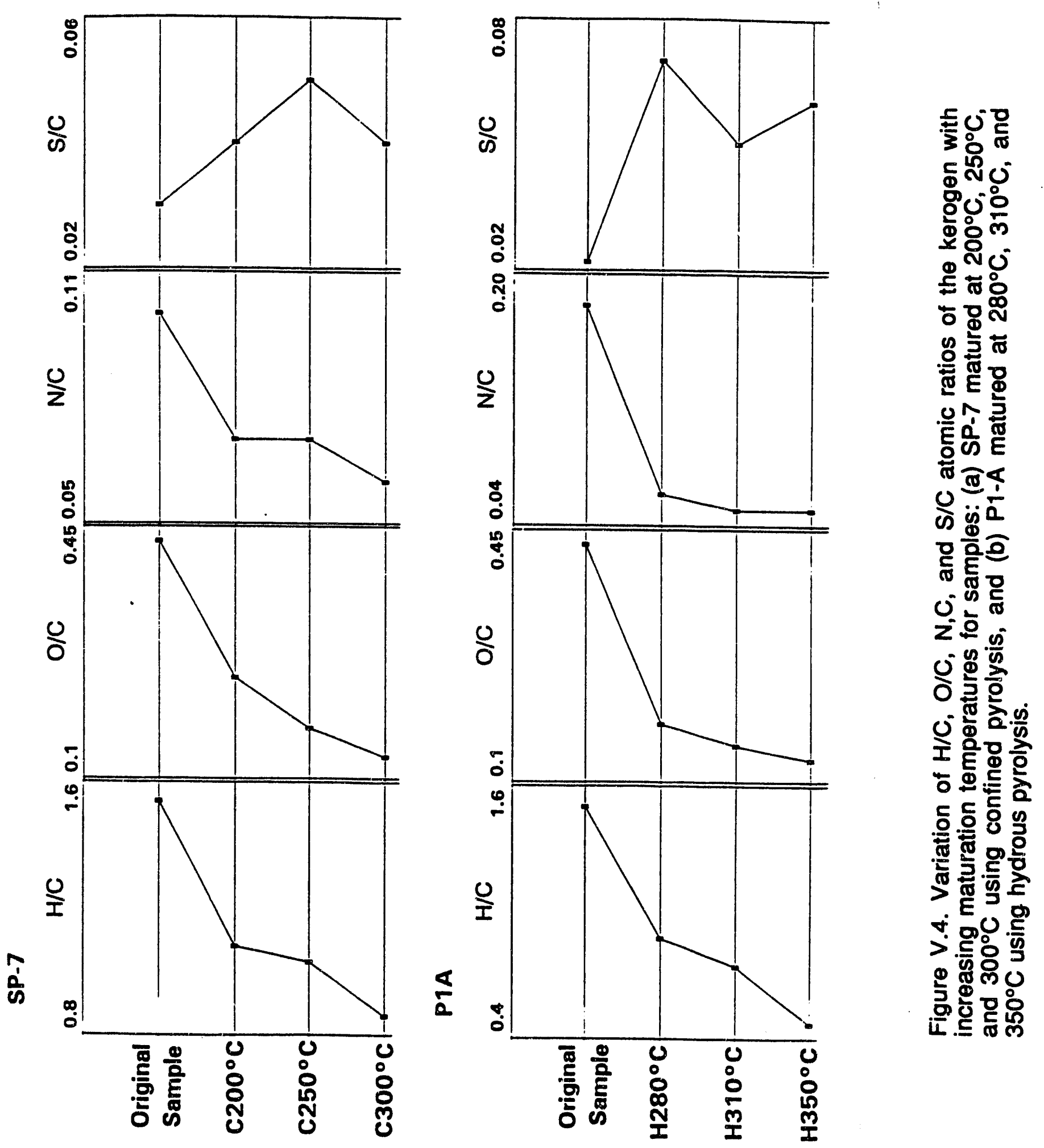
increasing amounts of resins, aromatics and saturates, and a decrease in the amounts of asphaltenes with maturation temperatures. Such changes in the composition of the extractable organic matter resemble those occurring in natural systems..

\section{Study of the generated hydrocarbons using GC and GC-MS.}

\section{a. Marine lake evaporites}

The extractable compounds from the original samples representative of different salinities are dominated by sterols and fatty acids (Table 2). Their saturated fractions are dominated by a hlghly branched $\mathrm{C}_{20}$ isoprenoid alkanes (Table 3 ). The changing yields of saturates, aromatics, resins and asphaltenes are accompanied by changes in isoprenoid and $\mathrm{n}$-alkane distribution and evolve progressively to an oil-like composition with its characteristic n-alkane distribution (Figure V.5b).

Distribution of the cyclic hydrocarbons from the pyrolysed samples at different temperatures show variations very close to those occurring in natural systems. The compounds were tentatively identified based on comparison of mass spectra and retention time as compared with published data: at low temperatures of pyrolysis $\left(\mathrm{C} 200^{\circ} \mathrm{C}, \mathrm{C} 250^{\circ} \mathrm{C}\right.$ and $H 280^{\circ} \mathrm{C}$; $\mathrm{C}$ refers to confined pyrolysis and $\mathrm{H}$ to hydrous pyrolysis), they are dominated by the unsaturated compounds (hopenes, $\mathrm{C}_{27}, \mathrm{C}_{28}$ and $\mathrm{C}_{29}$, sterenes, and $\mathrm{C}_{29}$ steradienes); at intermediate maturation temperatures $\left(\mathrm{C} 300^{\circ} \mathrm{C}\right.$ and $\mathrm{H} 310^{\circ} \mathrm{C}$ ), they are representsd by hopanes (Figure V.6 and Table 4), diasteranes (Figure V.7 and Table 5) and steranes (Figure V.8 and Table 6) with relative proportions of the isomers that are characteristic of organic matter at the threshold of maturity; at higher temperatures of maturation $\left(H 330^{\circ} \mathrm{C}, \mathrm{H} 350^{\circ} \mathrm{C}\right.$, $\mathrm{C} 350^{\circ} \mathrm{C}, \mathrm{H} 365^{\circ} \mathrm{C}$ and $\mathrm{C} 400^{\circ} \mathrm{C}$ ), the stercids and hopanoids are represented by diasteranes, steranes (Figure V.9 and Table 7) and hopanes (Figure V.I0 and Table 4) showing a composition and the maturity parameters of natural crude oils

(Table 8). Although gammacerane is absent in the saturated fraction of the original samples, this compound is present in small amounts in the extracts of the matured samples from temperatures $300^{\circ} \mathrm{C}$ and higher. Salinities appear not to have an influence on the relative amounts of gammacerane in the different samples.

The compounds present in the aromatic fraction of the lipid extract from pyrolysed samples contains more and more aromatized with increasing maturation 
A

B

C

TOTNL ETTRCT (x) SOTOPIC TPE-CUAVE

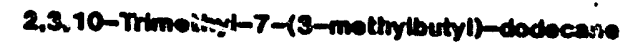
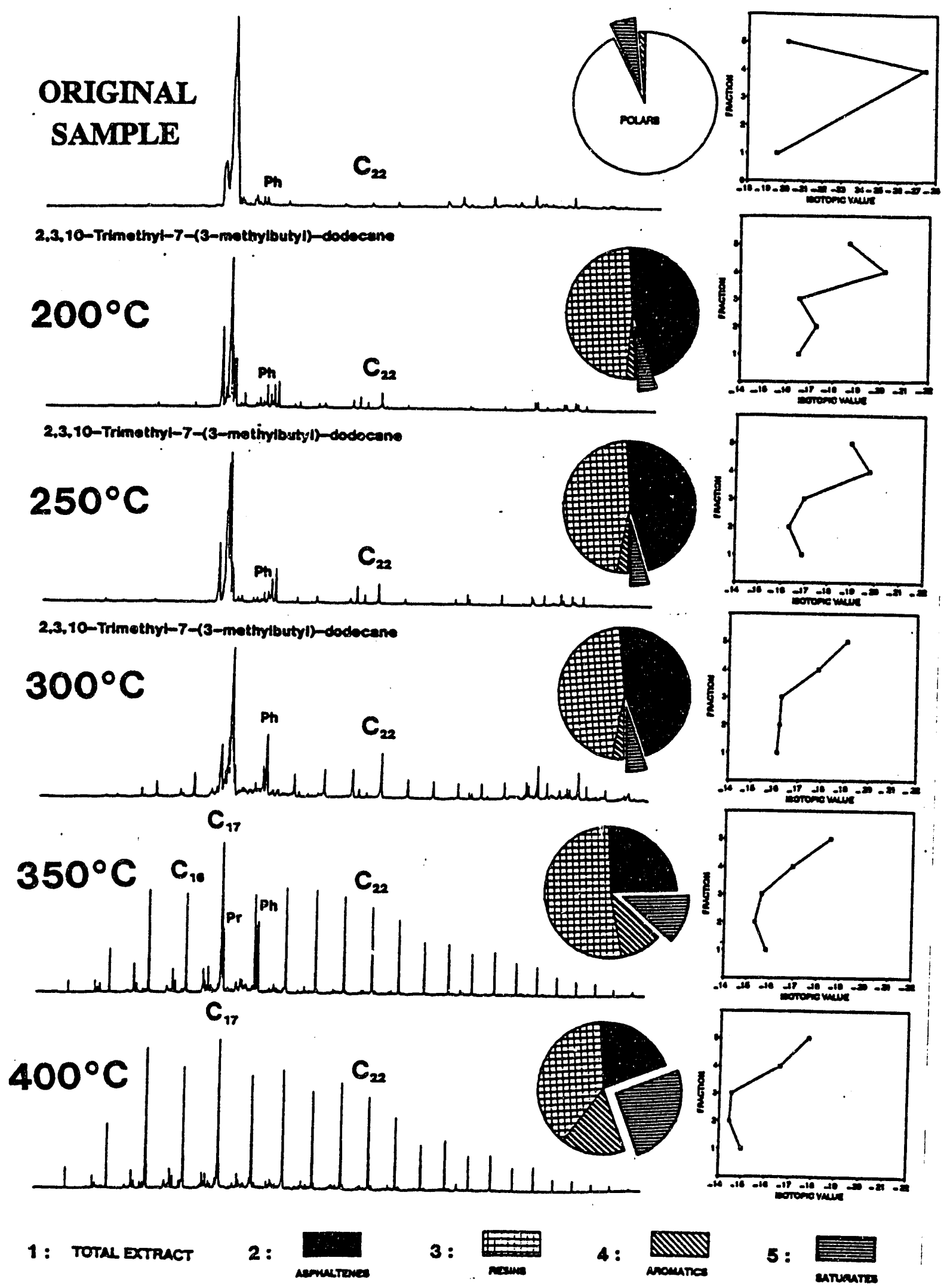

Figure V.5a. Analysis of the pyrolyzed SP-7 sample run at $200^{\circ} \mathrm{C}, 310^{\circ} \mathrm{C}, 350^{\circ} \mathrm{C}$, and $400^{\circ} \mathrm{C}$ (a Recent sediment taken from the carbonate/gypsum crystallizer ponds at Santa Pola, Spain), showing: (A) gas chromatograms of the saturated fractions; (B) total extracts composition; (C) isotopic type-curves of the total extracts, asphatenes, resins, aromatics and saturates 


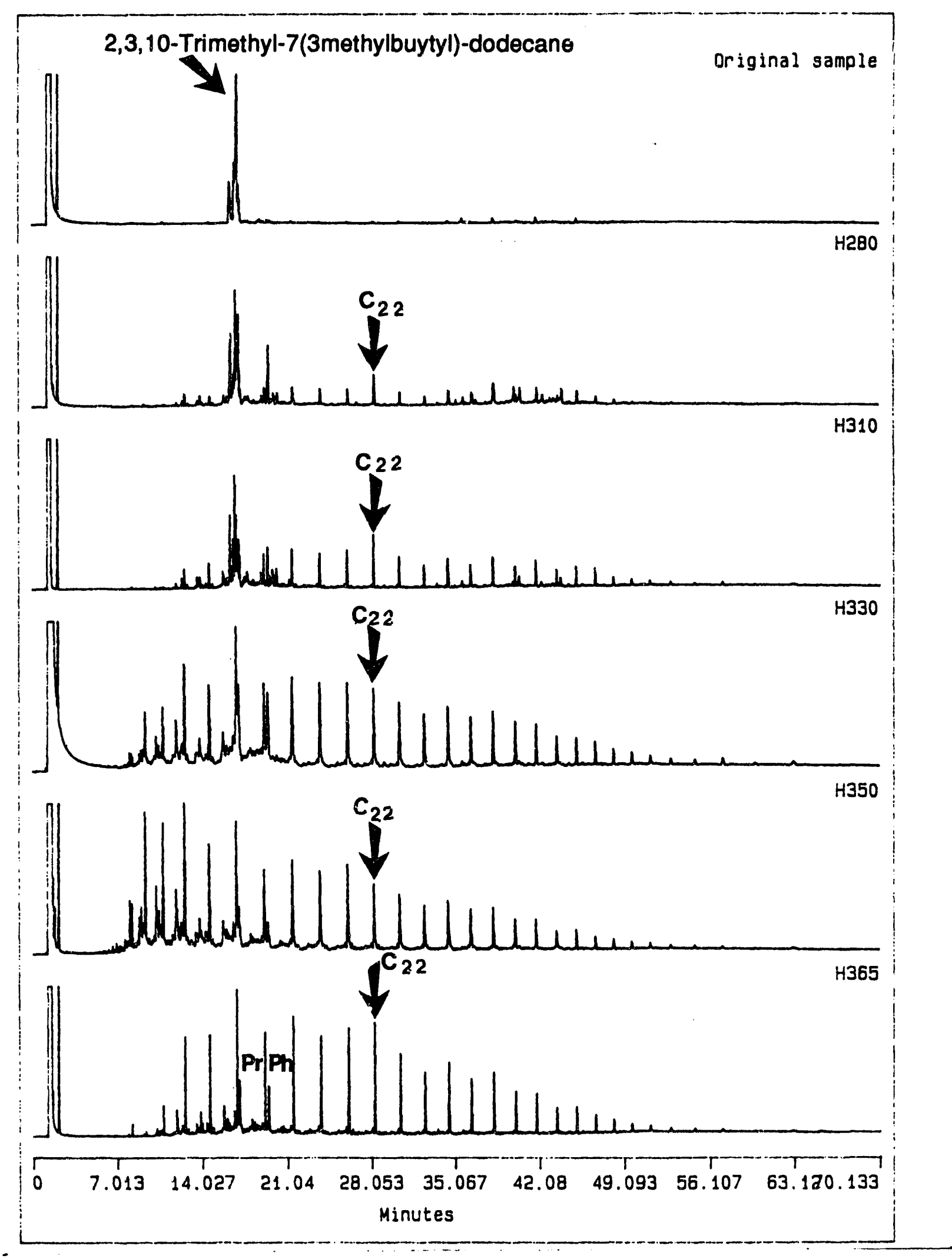

Figure 5b. Gas chromatograms of saturate fractions of the sample SP-7 before and after maturation at $280^{\circ} \mathrm{C}, 310^{\circ} \mathrm{C}, 330^{\circ} \mathrm{C}, 350^{\circ} \mathrm{C}$, and $360^{\circ} \mathrm{C}$ using hydrous pyrolysis. 


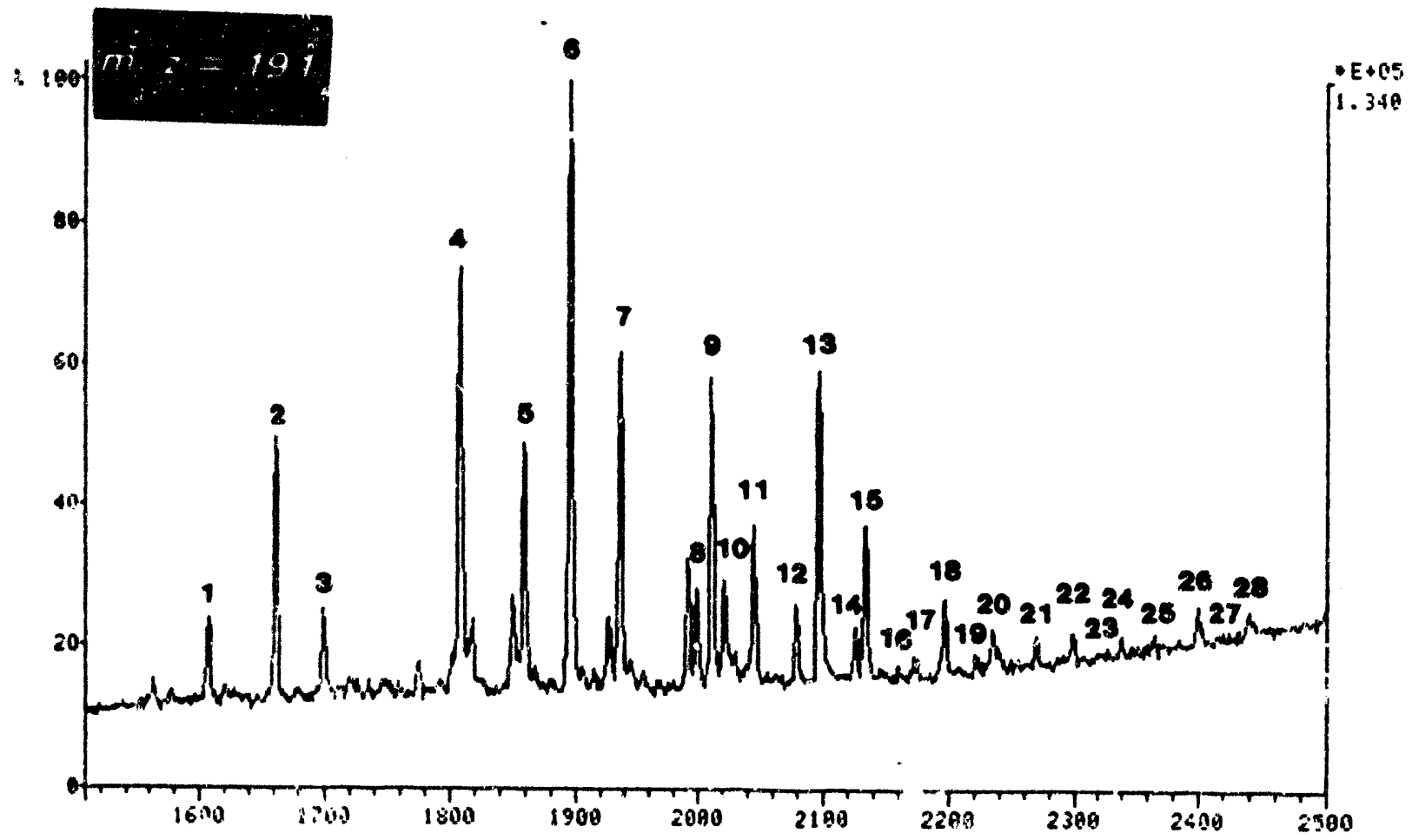

Figure V.6. Ion chromatograph $\mathrm{m} / \mathrm{z}=191$ showing the distribution of hopanes present in the saturated fraction of sample SP-7, matured at $300^{\circ} \mathrm{C}$ using confined pyrolysis. 


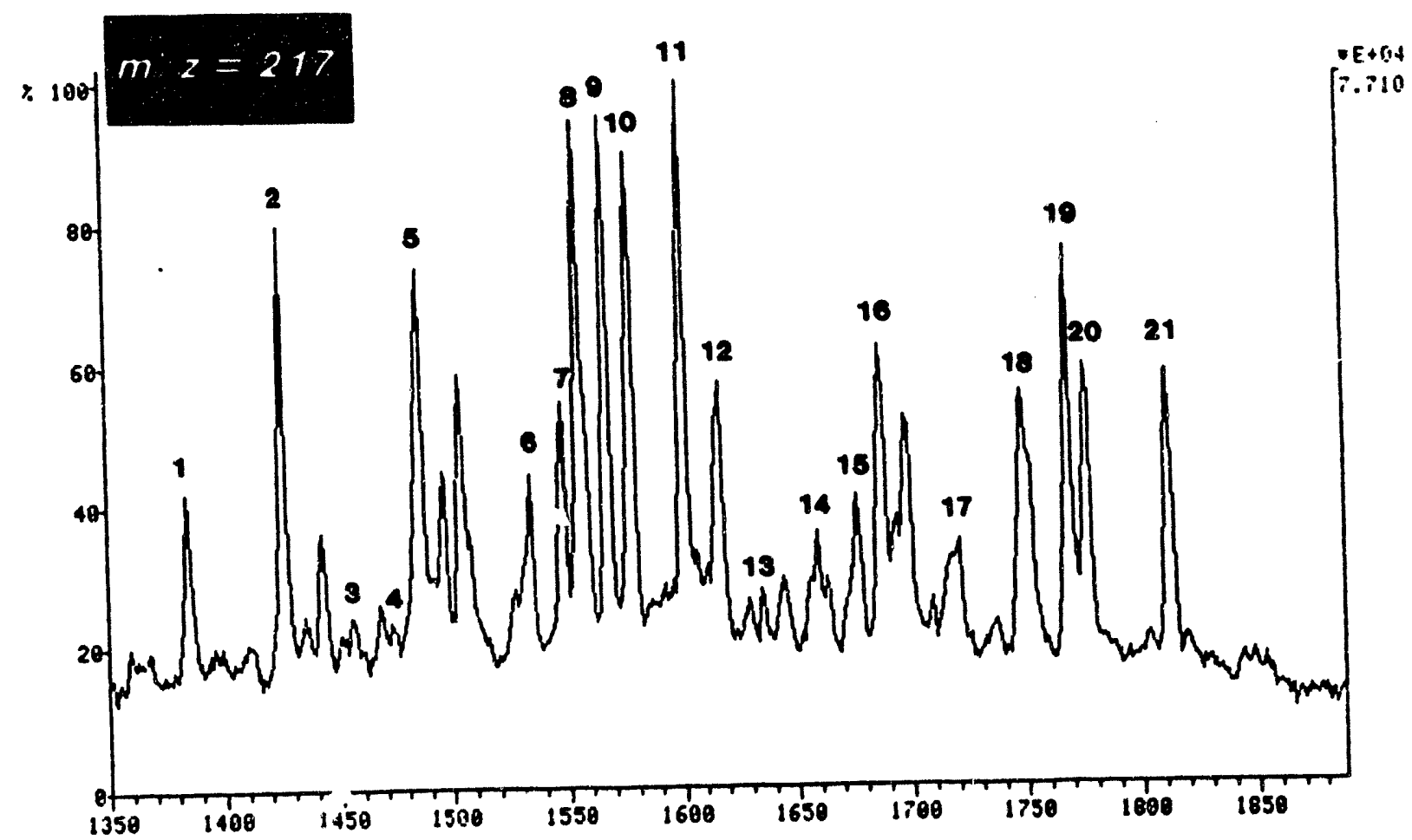

Figure V.7. Ion chromatograph $\mathrm{m} / \mathrm{z}=257$ showing the distribution of disterenes in the saturated fraction of the sample SP.7 matured at $300^{\circ} \mathrm{C}$, using confined pyrolysis. 


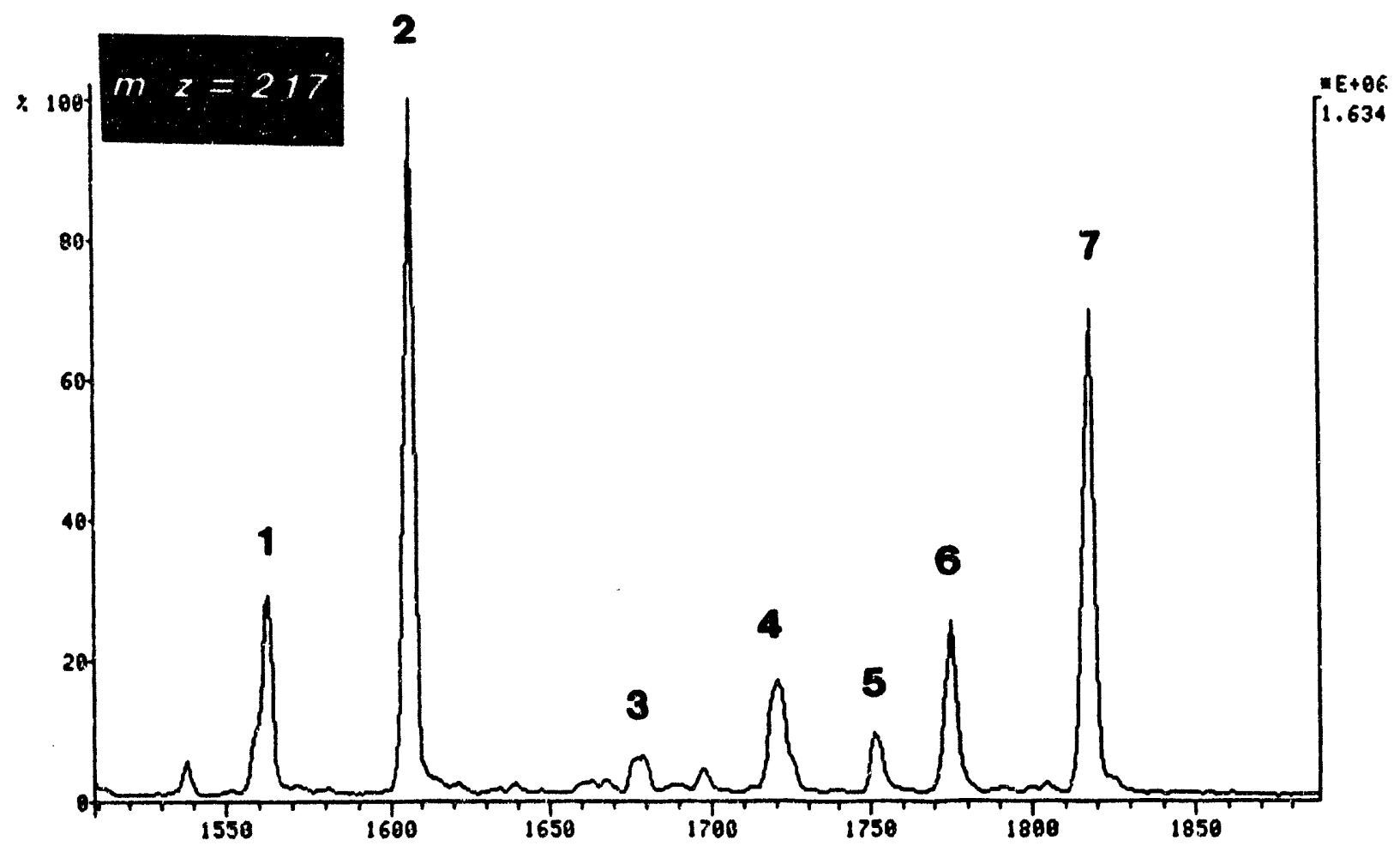

Figure V.8. Ion chromatogram $m / z=217$ showing the distribution of steranes present in the saturated fraction of sample SP-7 matured at $3000 \mathrm{C}$, using confined pyrolysis. 


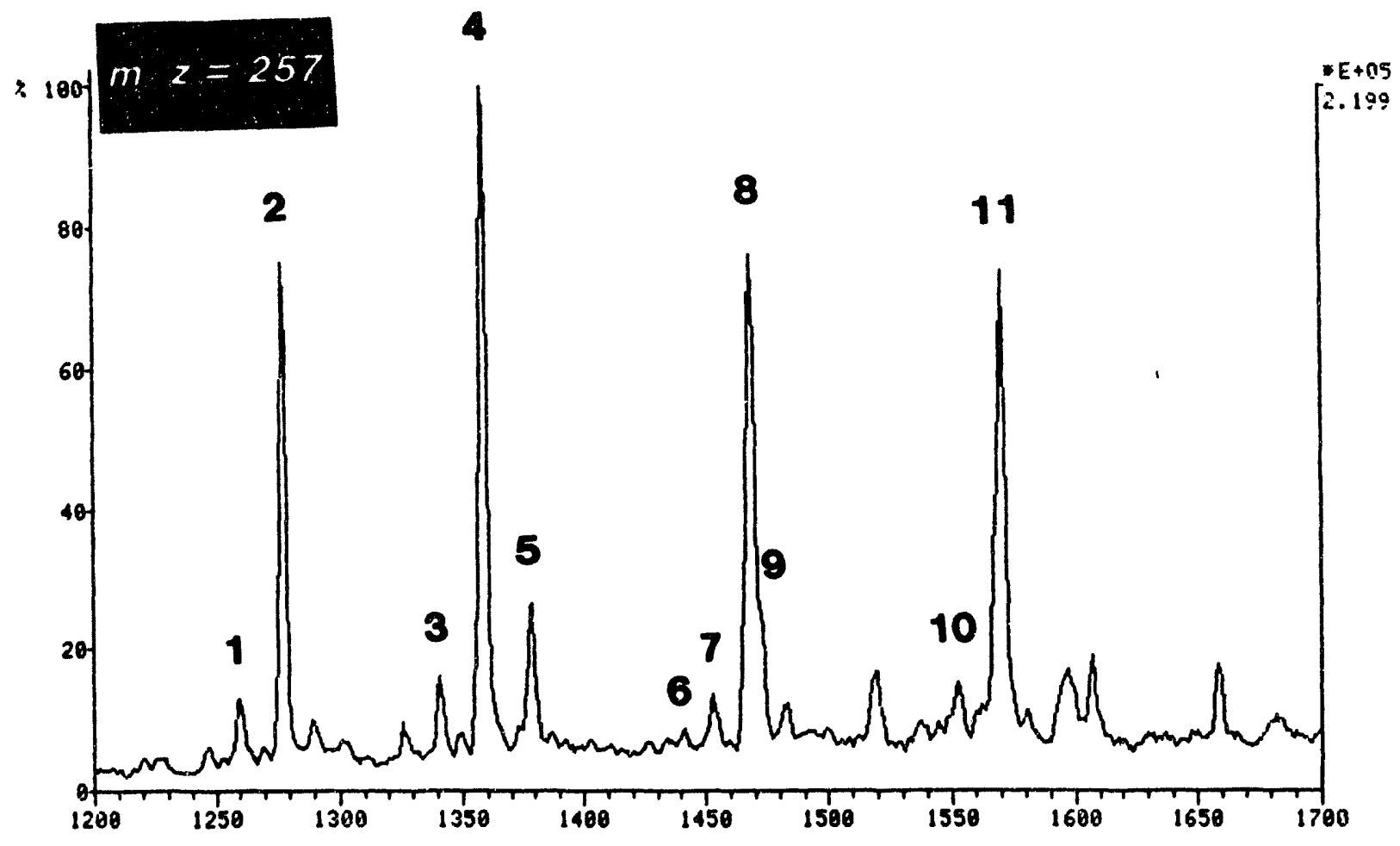

Figure V.9. Ion chromatogram $\mathrm{m} / \mathrm{z}=217$ showing the distribution of steranes present in the saturate fraction of sample SP-7 matured at $3500 \mathrm{C}$, using confined pyrolysis. 

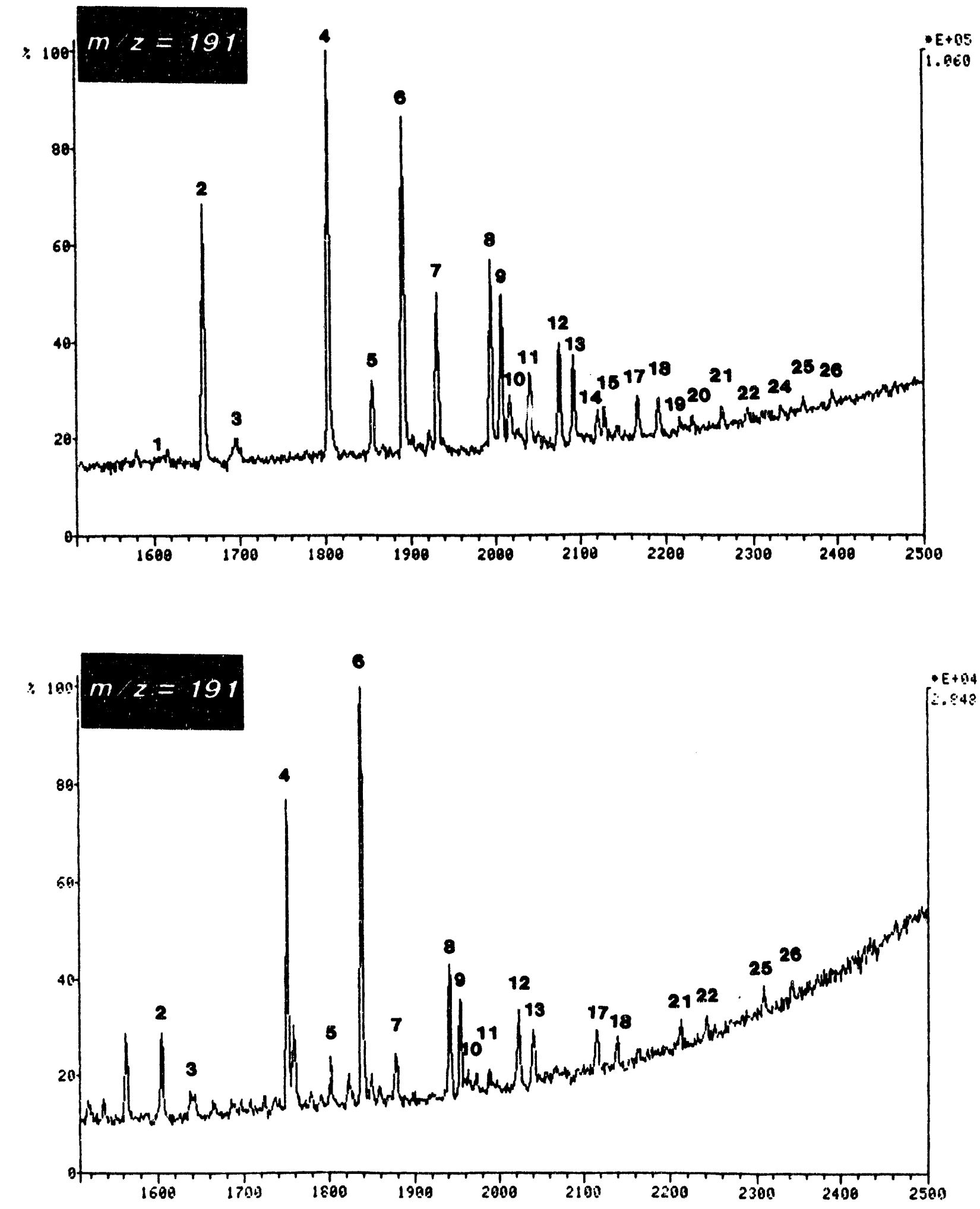

Figure V.10. Ion chromatograms $\mathrm{m} / \mathrm{z}=191$ showing the distribution of hopanes present in saturate fractions of sample SP-7 matured at, (a): $3500 \mathrm{C}$ and (b): $4000 \mathrm{C}$, using confined pyrolysis. 
temperatures (Table 8). At $\mathrm{C} 200^{\circ} \mathrm{C}, \mathrm{C} 250^{\circ} \mathrm{C}$ and $\mathrm{H} 280^{\circ} \mathrm{C}$ the aromatic fractions contain the $\mathrm{C}_{20}$ isoprenoid thiophenes: 3-(4,8,12-trimethyl-tridecyl) thiophene, 3-methyl-2(3,7,11-trimethyl-dodecyl) thiophene ard 2,3-dimethyl-5-(2,6,10-trimethyl-undecyl) thiophene, alkylthiophenes, alkylbenzoftujtiophenes and the methylated chromans: 8Me-MTTC, 7,8-diMe-MTTC and 5,7,8-tri-Me-MTTC. At (C300, $\mathrm{H} 310^{\circ}$ and $\left.\mathrm{H} 330^{\circ} \mathrm{C}\right)$ the monoaromatic steroids and triaromatic steranes appear. At $\left(\mathrm{C} 350^{\circ}, \mathrm{C} 400^{\circ}, \mathrm{H} 350^{\circ}\right.$ and $\mathrm{H} 365^{\circ} \mathrm{C}$ ) the aromatic hydrocarbons are fully aromatized, including: naphtalenes (mono-, di-, trimethyl-), phenamtrenes (mono-, di-, trimethyl-), anthracenes and Diels' hydrocarbons $\left(C_{18}\right)$.

\section{Variation in $\delta^{13} \mathrm{C}$ values}

The variations of the istopic composition of the different fractions (saturates, aromatics, resins and asphaltenes) and the total extract of the sample SP-7 with increasing maturation are shown in Figure V.11. The isotopis compositions observed at low maturation temperatures $\left(\mathrm{C}^{2} 20^{\circ} \mathrm{C}\right.$ and $\left.\mathrm{C} 250^{\circ} \mathrm{C}\right)$ appear to result from a mixture of the original hydrocarbons and the thermalls generated hydrocarbons. the aromatic fraction of the original sample has a very low $\delta^{13} \mathrm{C}$ value $(-27.43)$ compared to the other fractions. At low temperatures of pyrolysis the aromatic fraction still shows the lowest $\delta^{13} \mathrm{C}$ value. With increasing temperature above $\mathrm{C} 300^{\circ} \mathrm{C}$ the isotopic composition $\left(\delta^{13} \mathrm{C}\right)$ becomes more and more positive for all of the fractions. These changes in the isotopic composition are similar to those occurring in nature where the generated hydrocarbons become isotopically enriched in $\delta^{13} \mathrm{C}$ with increased thermal alteration. The isotopic type-curves at temperatures of $C 300^{\circ} \mathrm{C}$ and higher all show the same trend (Figure V.5a). This similarity between the isotopic type-curves for different stages of maturation may prove the suitability of artificial maturation for the correlation crude oils with their source rocks when only immature source rocks are available for analysis.

b. Sabkha deposits.

Saturate fractions from the original and the matured samples at Al Qanatir contain high amounts of phytane. Distributions of the different cyclic hydrocarbons (unsaturated, saturated and aromatics) from the original and the matured samples, show the same characteristics as those described for the preceding samples.

\section{c. Continental Evaporites.}

Samples from continental evaporites can be divided into two groups, based on the ranges of organic content of the sediments and the dlstribution of the 


\section{A}

TOTAL EXTRACT (\%)
B

ISOTOPIC VALUE

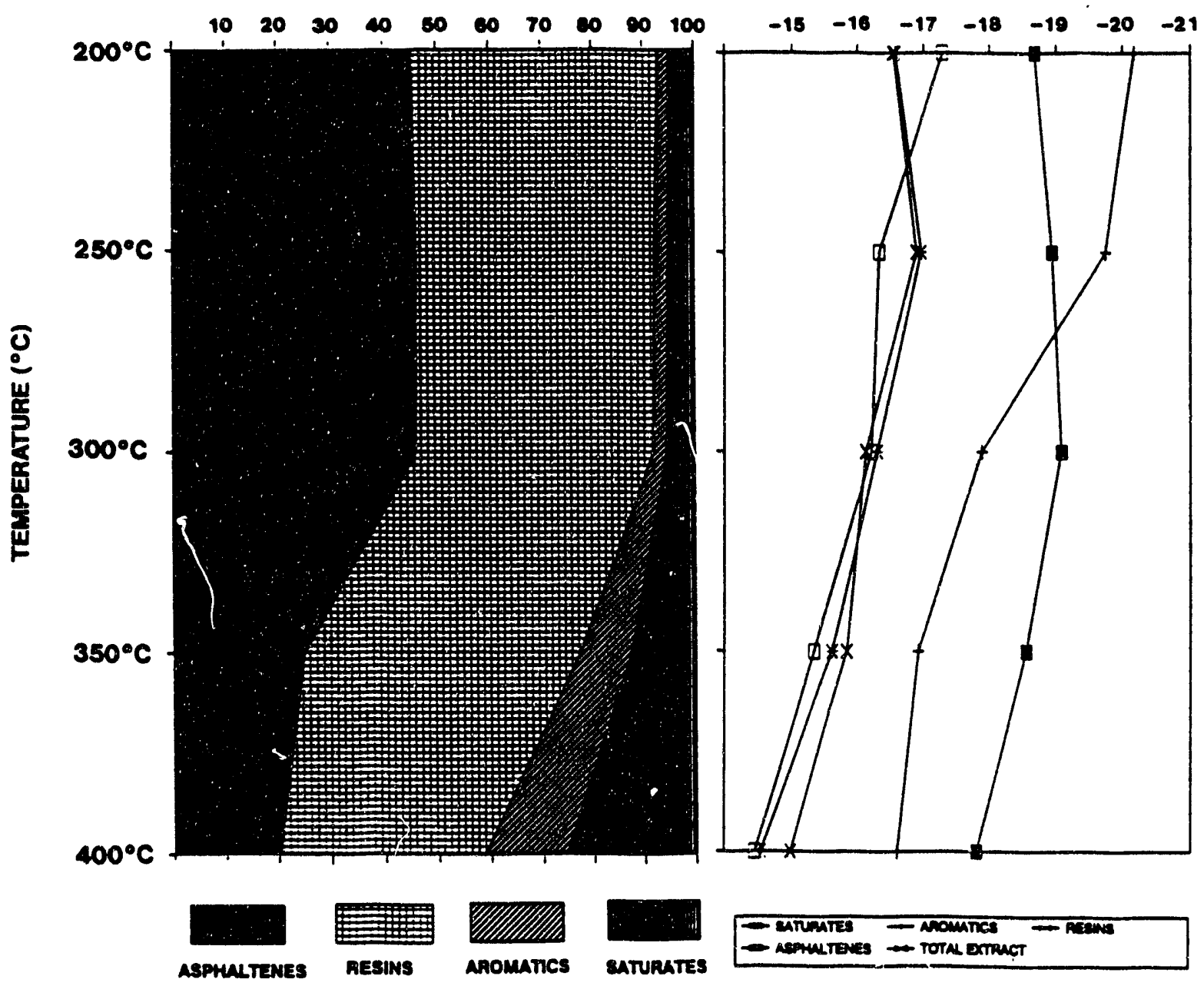

Figure V.11. (A) Plot showing changes in the relative amounts of saturates, aromatics, resins and asphaltenes recovred from the SP-7 sample pyrolysed at $200,250,300,350$ and $400^{\circ} \mathrm{C}$ using confined pyrolysis, and (B) variation in $\delta^{13}$ values of the saturates, aromatics, resins, asphaltenes and total extract. 
hydrocarbons extracted from the original and the matured samples. This differentiation has already been observed when studying the organic matter using elemental analysis and Rock-Eval pyrolysis of the isolated kerogen from the original samples.

\section{c I.Samples from Tirez and Quero lakes.}

In the western portion of La Manchia (Province of Toledo, Spain), in the Tirez and Quero playas, rapid deciccation resulted in almost total destruction of the organic matter on the rims of the playas, while a relatively small amount of organic, matter (TOC <1\%), probably due to a partial degradation, is preserved in the central parts of the playas. The saturate fractions of the original samples and the matured samples (Figure V.12) show a bimodal distribution of the n-alkanes with a strong odd/even predominance among the high carbon number $n$-alkanes and $\mathrm{Pr} / \mathrm{Ph}<1$.

These features, together with the low H/C atomic ratio and Hydrogen Index of the isolated kerogen from the original samples, are probably due to oxidizing conditions prevailing In the playas during the period of desiccation. The variation, with increasing temperature of the composition of the total extract, and the distribution of the saturated hydrocarbons (hopanes and steranes) and the aromatic compounds (sulfur compounds, chromans, monoaromatic steroids, triaromatic steranes, napthalenes, phenamtrenes and anthracenes) show the same features as those described for samples from marine lake evaporites.

\section{c.2. Samples from Petrola and Saladar}

In eastern La Manchla, in the Petrola area (Albacete) and Saladar, desiccation is either absent or far less pronounced than in the western portion of la Manchia. Reducing conditions, probably due. to low oxygen diffusion and/or stratification of the water column during the deposition of the organic matter, resulted in a high level of presenvation (T.O.C. $>4 \%$ ). Contrary to saturate fractions from samples belonging to Tirez and Quero lakes, the odd/even predominance among the high carbon number $\mathrm{D}$-alkanes is less pronounced and the $\mathrm{Pr} / \mathrm{Ph}<\mathrm{I}$ (Figure V.13). A feature distingushing samples from Petrola and Saladar is the relative abundance of gammacerane (Figure V.14) in their saturated fraction. This compound is known to be a characteristic biomarker of lacustrine sediments deposted under sallne and reducing conditions (Peters and Moldowan, 1993). 


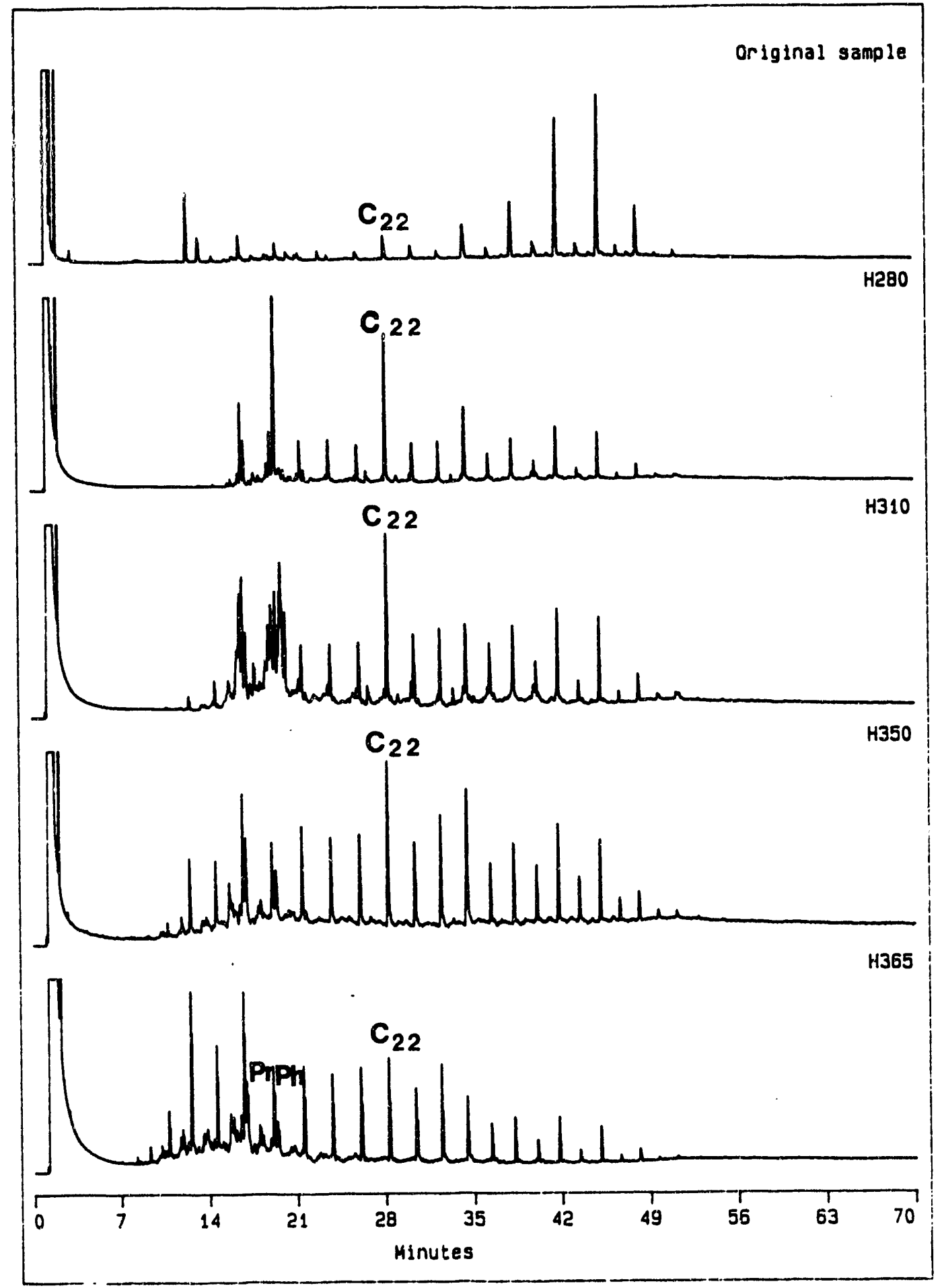

Figure V.12. Gas chromatograms of saturate fractions of the sample Quero-1 before and after maturation at $280^{\circ} \mathrm{C}, 310^{\circ} \mathrm{C}, 350^{\circ} \mathrm{C}$, and $365^{\circ} \mathrm{C}$ using hydrous pyrolysis. 


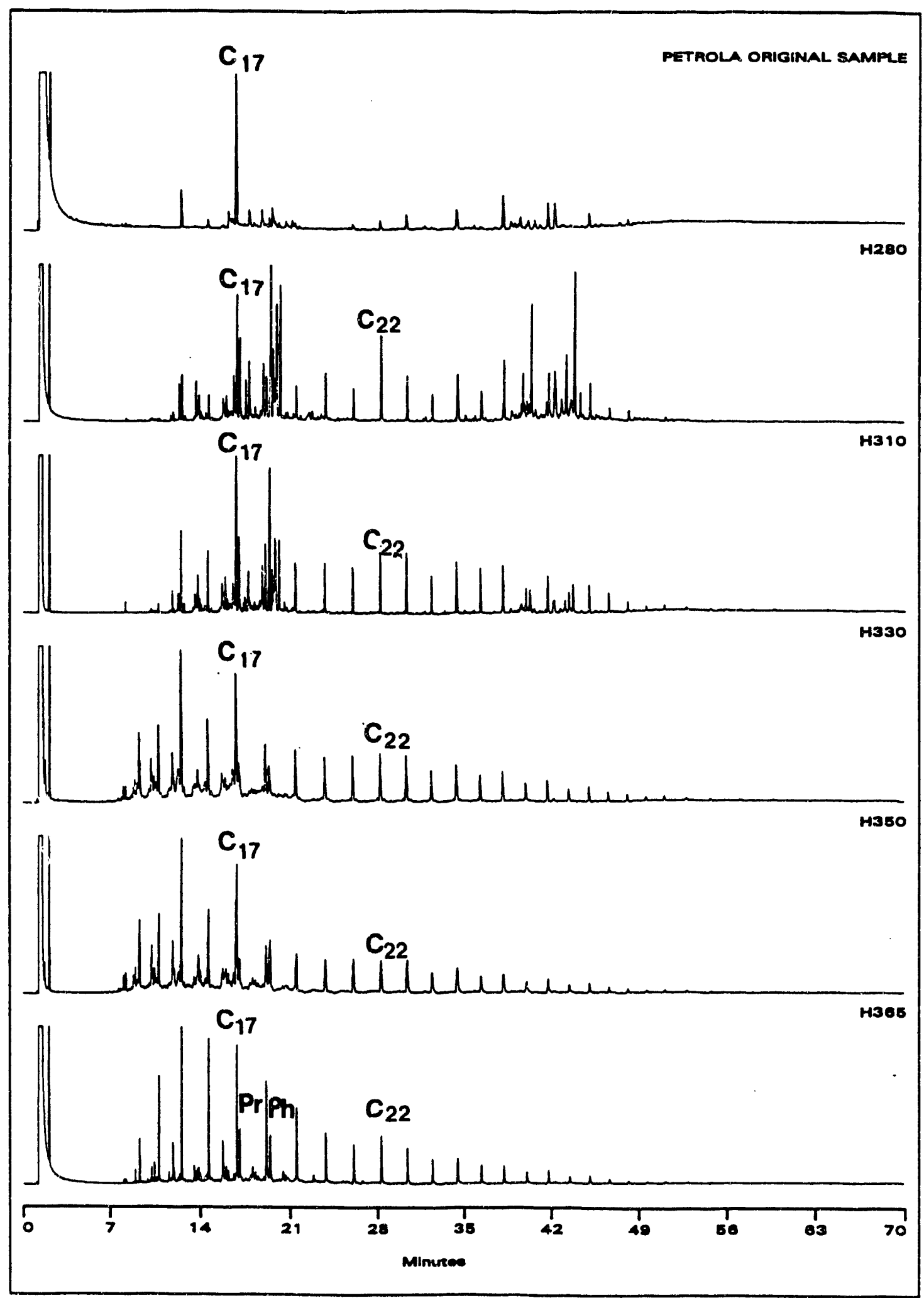

Figure V.13. Gas chromatograms of saturate fractions of the sample P1-A before and after maturation at $280^{\circ}, 310^{\circ}, 330^{\circ}, 350^{\circ}$ and $365^{\circ} \mathrm{C}$, using hydrous pyrolysis. 

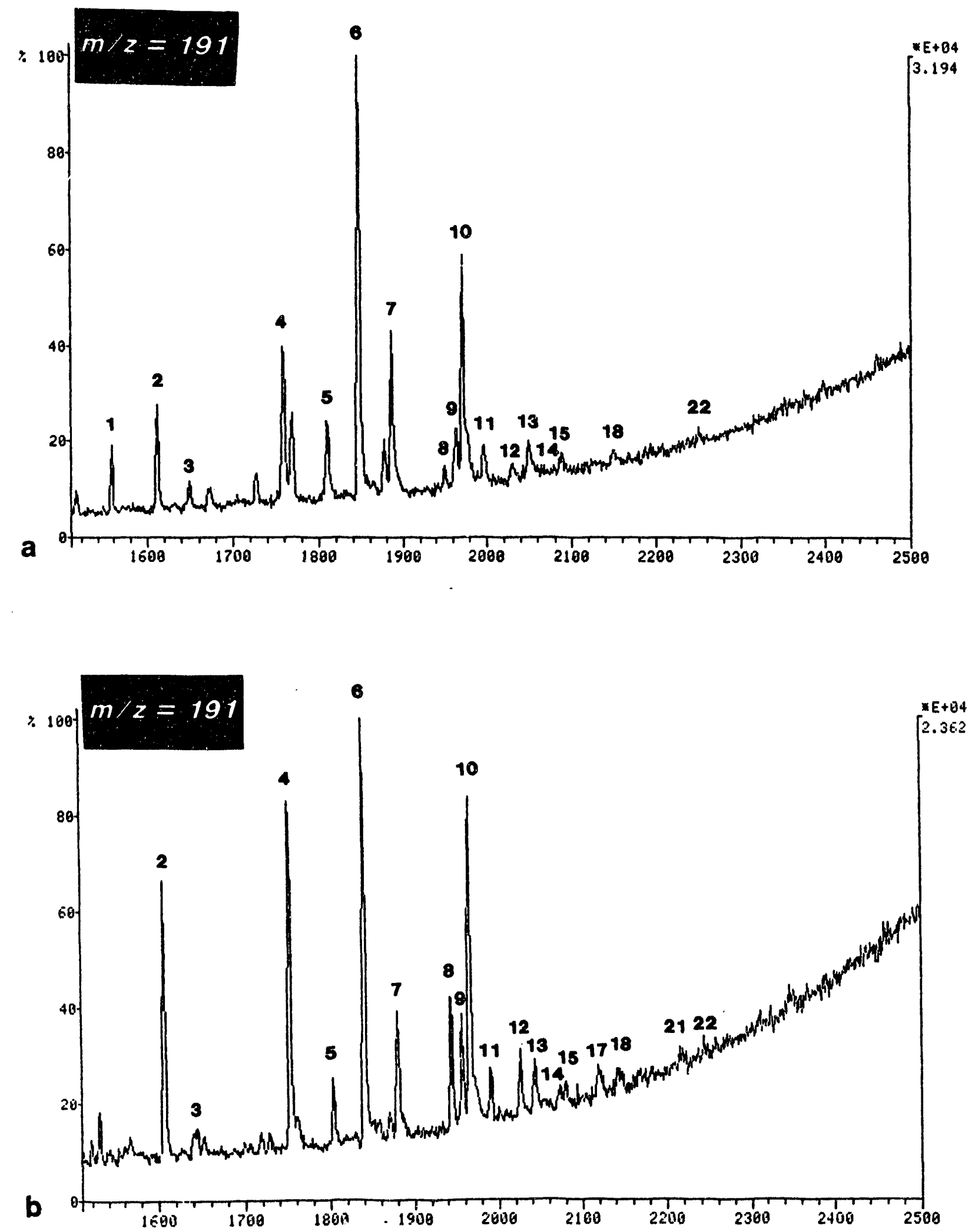

Figure $\mathrm{V} .14$. Ion chromatograms $\mathrm{m} / \mathrm{z}=191$ showing the distribution of hopanes present in the saturate fractions of sample P1-A matured at, (a): $3000 \mathrm{C}$ and (b): at $3500 \mathrm{c}$, using confined pyrolysis. 


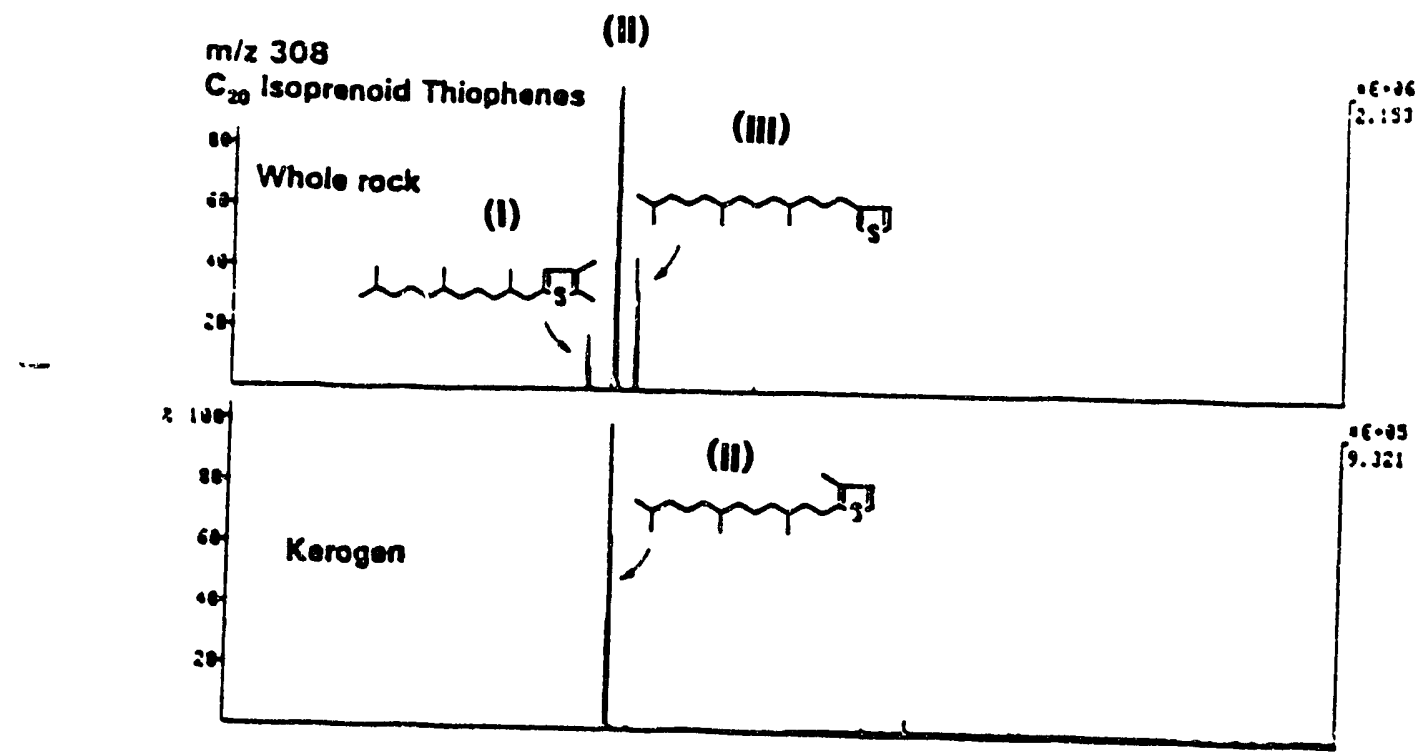

(a)

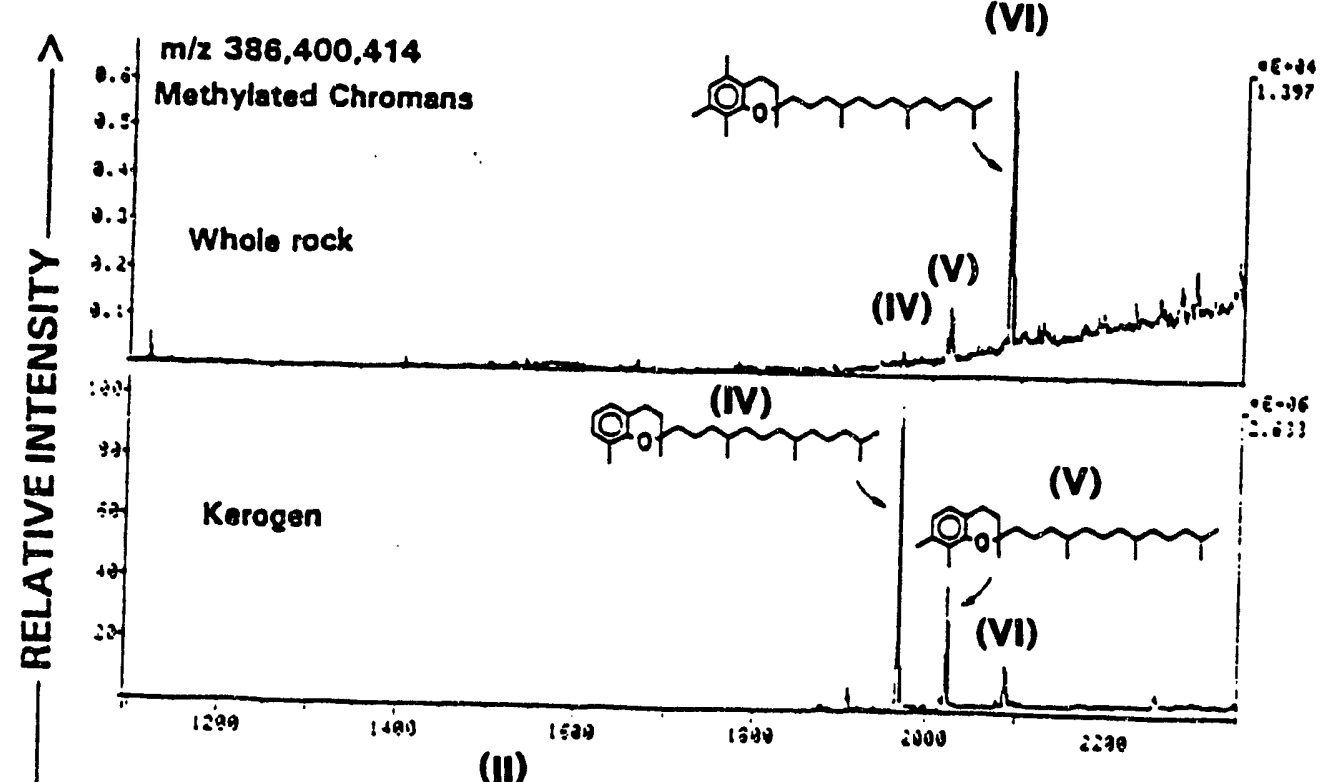

(b)

(c)

(d)

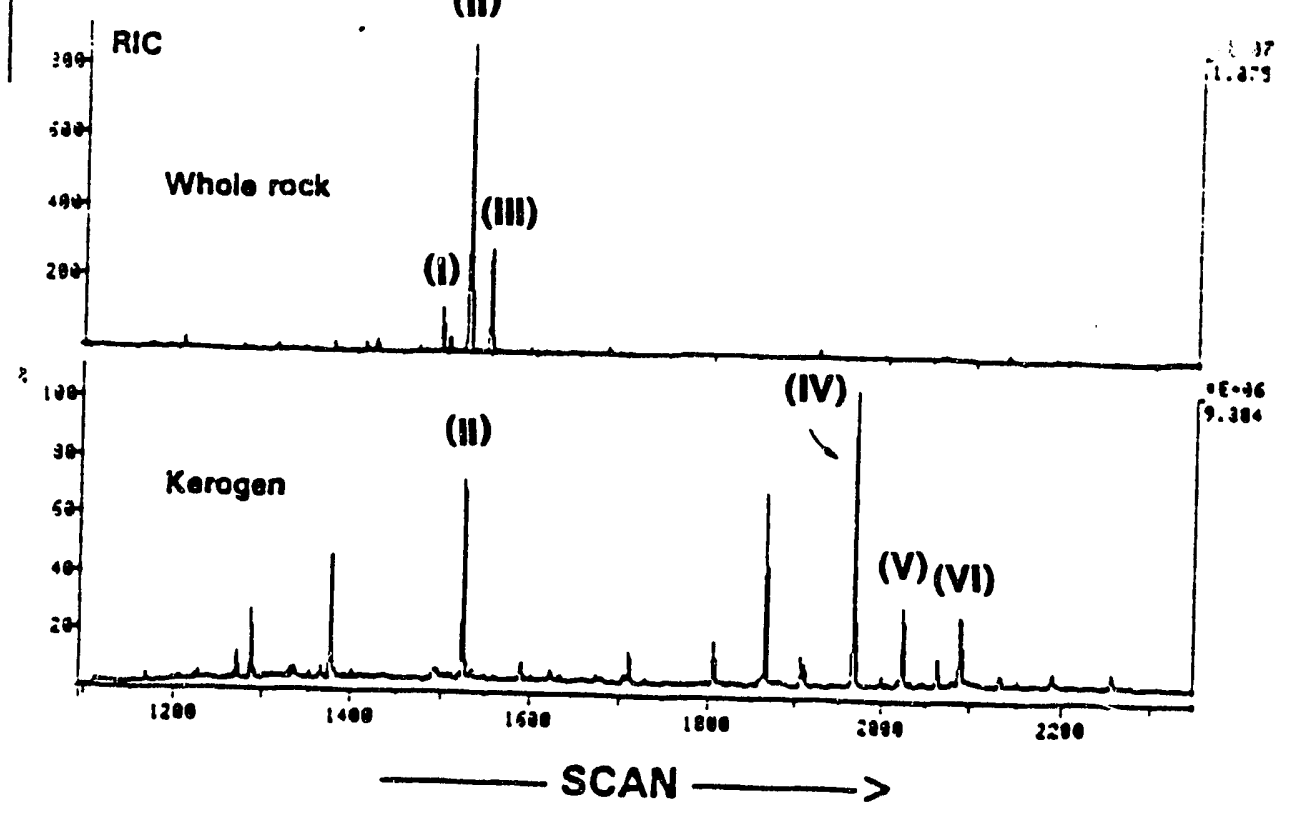

(e)

(f)

Figure V.15. MID ion chromatograms showing the distribution of $\mathrm{C}_{20}$ isoprenoid thiophenes and methylated chromans in the aromatic fraction of the sample P1-A after maturation at $280^{\circ} \mathrm{C}$ using hydrous pyrolysis. Molecular formulae of compounds I, II, III, IV, $\mathrm{V}$, and $\mathrm{VI}$ are listed in Table 9). 


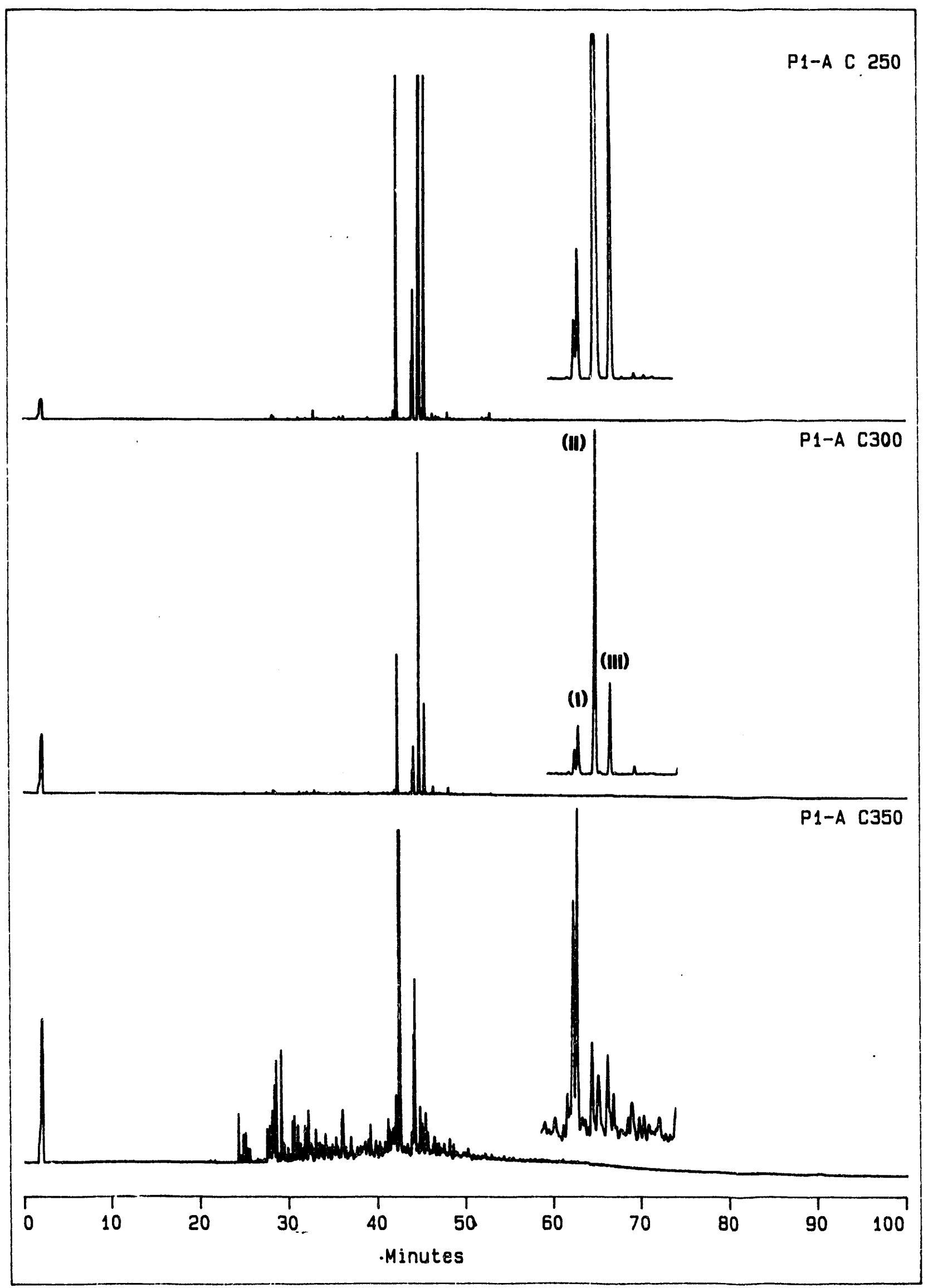

Figure V.16. FPD ion chromatograms shcwing the distribution of the sample P1-A C20 isoprenoid thiophenes and methylated chromans in the aromatic fraction after maturation at $280^{\circ} \mathrm{C}, 310^{\circ} \mathrm{C}, 350^{\circ} \mathrm{C}$, using confined pyrolysis. Molecular formulae of compounds I, II, III are listed in Table 9). 


\section{Assessment of biomarkers characteristic of hypersalinity}

The increasing recognition of evaporites for their potential as a source rock for oil has led to several studies aimed at the characterization of hypersaline paleoenvironments using biomarkers (Sinninghe Damsté et al., 1989; de Leeuw and Sinninghe Damsté, 1990). The study of immature organic-rich sequences associated with evaporative depositional sequences and the study of oils related to evaporitic systems provided several parameters that correlate with ranges of salinity in the depositional environment. Ratios using different isomers of $\mathbf{C}_{20}$ isoprenoid thiophenes and the methylated chromans are the most relevant parameters. Low Pr/Ph ratio and abundance of gammacerane are also considered as indicators of paleosalinit.y in the environment of deposition. Sediments from recent environments also have been studied in order follow changes in biomarker composition relative to salinlty (Barbe et al., 1990).

This study of the biomarkers present in the saturated and the aromatic fractions of samples which are representative of the various recent evaporitic eniironments (marine evaporites, marine sabkha deposits and continental evaporites), has revealed the existence of biomarkers that are characteristic of hypersalinity, specific to each type of environment (Table 9). In addition, changes to these biomarkers as a result of thermal alteration and mineral matrix effects have been evaluated through the use of artificial maturation of the sediments (with the associated organic matter) and then of isolated kerogen from the original samples.

Highly--branched $\mathrm{C}_{20}$ isoprenoid alkane: This compound (Table 3 ) has been recognized in several hypersaline environments (Robson and Rowland, 1986; ten Haven et al., 1988; Barbe et al., 1990; Kenig et al., 1990). This compound is also present as the second major compound after phytane in the saturated fraction of Rozel Point oil (Yon et al., 1982). This oil has been correlated with a source rock deposited in a hypersaline environment. With respect to our samples, this $C_{20}$ isoprenoid alkane dominates the saturated fraction of samples from the carbonate domain in the marlne evaporites (salina at Santa Pola), and it is present in lower amounts in samples frcm the gypsum and halite domains of this salina. It is also found in samples from sabkha deposits at Al Qanatir in the Persian Gulf. However, none of our samples from lakes representing continental evaporites contain this compound. 
The origin of this $C_{20}$ isoprenoid alkane is still unknown. Its presence in the semples representing marine sabkha deposits and marine salinas, and its absence in continental evaporitic lakes could be related to the adaptation of its precursor organisms to specific conditions within the hypersaline depositional environment .

Pristane/Phvtane ratio: Low $\mathrm{Pr} / \mathrm{Ph}$ ratios are typical of hypersaline environments (ten Haven, 1985; ten Haven ot al., 1988; Fu Jiamo ot al., 1988). A ratio Pr/Ph>1 is observed for all the samples except those from Tirez and Quero. The ratio Pr/Ph observed for samples from these playas confirms their particularity with regard to samples from the other locations (i.e. input of terrestrial organic matter under oxidizing conditions inferred by the desiccation during the dry season of the year).

Gammaerane: Gammacerane appears to be derived by a reduction of tetrahymanol (ten Haven et al., 1989; Venkatsean 1989) and appears to represent a marker for highly saline marine and nonmarine depositional environments (Peters and Moldowan, 1993). It is a major biomarker in many lacustrine oils and bitumens (Hills et al.,1966; Moldowan et al., 1985; Jiang and Fowler, 1986; Fu Jiamo et al.,1986, 1988; Brassel ot al., 1988). Although absent in almost all the extracts from the original samples, this compound is present in at least small amounts in the pyrolyzed samples from the different saline environments we are studying, and as a major compound in the pyrolysed samples from the different saline environments we are studying, and as a major compound in the pyrolysed samples of lacustrine evaporites from Petrola lake..

Large amounts of gammacerane indicate highly reducing, hypersaline conditions in the environment of deposition of the organic matter (Moldowan et al., 1985; Fu Jiamo et al., 1986). This may explain the abundance of this compound in samples representing lacustrine evaporites, from Petrola where the organic matter was deposited under reducing conditions. This may also explain its presence in only small amounts in samples from Quero and Tirez where the desiccation contributed to periods of oxidizing conditions.

Chromans: Sinninghe Damsté et al. (1987b) have demonstrated a relationship between the distribution of the methylated chromanes and salinity in the environment of deposition. These authors have suggested that the predominance of compound IV: 8-Me-MTTC (Flgure V.15) over compounds V: 7, 8-diMe-MTTC and $\mathrm{Vl}: 5,7,8$-triMe-MTTC indicates hypersalinity in the environment of deposition. 
Methylated chromans are present in the aromatic fraction of the matured kerogen extracts and show a distribution that is characteristic of hypersalinity (Figure V.15d and f). This is not the case for the matured sediments and the matured extracted sediments. Interactions between the mineral matrix and the organic compounds, during the maturation process, might have altered the chromans' fingerprint inherited from the original biomass. Furthermore, methylated chromans disappear with increasing maturation temperature.

Sulfur compounds: the aromatic fractions from the matured sediments and kerogens are very rich in sulfur compounds. Oils related to evaporative envronments are often rich in organic sulfur compounds (ten Haven et al., 1988).

With respect to the maturation of whole reck and extracted rock, $C_{20}$ isoprenoid thiophenes are abundant among the aromatic fraction at low pyrolysis temperature, represented by compounds 2,3-dimethyl-5-(2,6,10-trimethylundecyl) thiophene (1); 3-methyl-2-(3,7-1-trimethyl-risdecyl) thiophene (II); and 3-(4,8,12-trimethyltridecyl) thiophene (III), (Figure V.15 a and e). Compound (II) is the most abundant $\mathrm{C}_{20}$ isprenoid thiophene while abundance of isomer (I) is usually considered as an indication of hypersalinity (Sinninghe Damsté et al., 1987a, 1990). Also, the relative proportions of these three isomers change with increasing maturation temperature (Figure V.16).

The isomers (I) and (III) are absent from the aromatic fraction of the matured kerogen extracts (Figure V.15 $b$ and $f$ ). Because.it has heen proposed that isoprenoid thiophenes result from the reaction of $\mathrm{H}_{2} \mathrm{~S}$ with phytadienes (Fukushima et al., 1992), compound (II) might have been the first isomer to be formed and bound to the kerogen, hence it is the only one to be released during the maturation of that kerogen.

\section{Conclusion to the study of organic matter from recent evaporative environments}

Elemental analyses and Rock-Eval pyrolysis carried out on the kerogen isolated from the original samples show organic matter deposited in recent evaporitic environments is highly rich in hydrogen. Under good conditions of preservation during its evolution, it might provide a potential source rock. 
Artificial maturation using confined and hydrous pyrolysis has enabled us to follow the evolution of organic matter, from a wide range of recent evaporative environments, from deposition through to maturation. The lipids released during maturation closely resemble natural crude oils in their broad characteristics and composition. Therefore, we can compare the nature of characierisic biomarkers produced in each of the studied hypersaline environments, and their evolution with maturation, to those produced in natural systems.

Although either absent or present only in small amouns in the original samples, several biomarkers characteristic of hypersalinity in the environment have been identified in the matured samples. The compounds that were found to be the most useful are:

- The highly branched $\mathrm{C}_{20}$ isoprenoid alkane (Table 3), particularly abundant in samples from the evaporative carbonates of marine-lake evaporite sediments. -Gammacerane, particularly abundant in samples from lacustrine evaporative sediments deposited under reducing condtitions.

- Methylated chromans showing a distribution characteritic of hypersalinity.

$-C_{20}$ isoprenoid thiophenes.

The biomarkers characteristic of hypersalinity provided by the literature are not omnipresent in the different evaporitic environments we have studied and the proposed parameters could not always be used with confidence to assess the salinity in the depositional environment. The distribution of $\mathrm{C}_{20}$ isoprenoid thiophenes and methylated chromans varies with increasing maturity and is subject to the mineral matrix effects. Caution is necessary when using these compounds to characterize and compare salinities of depositional environments for organic matter or oils with different maturities and related to different lithologies. Therefore the hypersalinity of a depositional environment can only be assessed through a series of criteria. Some are not always applicable. However, the supporting relationship between the various crtteria.is an indicator of hypersalinity. 


\begin{tabular}{|c|c|}
\hline \multicolumn{2}{|c|}{ ACIDIC FRACTION } \\
\hline $\begin{array}{c}\text { LINEAR FATTY } \\
\text { ACIDS }\end{array}$ & $\begin{array}{c}\text { ranging from } \mathrm{C}_{14} \\
\text { to } \mathrm{C}_{24} \text { with maximum at } \\
\mathrm{C}_{16} \text { and } \mathrm{C}_{24} \\
\text { even/odd predominace }\end{array}$ \\
\hline $\begin{array}{c}\text { UNSATURATES } \\
\text { ISO- AND ANTEISO- } \\
\text { FATTY ACIDS }\end{array}$ & $\mathrm{C}_{16}: 1$ and $\mathrm{C}_{18}: 1$ \\
\hline $\begin{array}{c}\text { CYCLIC FATTY } \\
\text { ACIDS }\end{array}$ & $\mathrm{bC}_{14}, \mathrm{bC}_{15}$ and $\mathrm{b} \mathrm{C}_{17}$ \\
\hline LACTONES & $\mathrm{YC}_{19}$ \\
\hline HOPANOID ACIDS & $\mathrm{C}_{17}$ and $\mathrm{C}_{19}$ \\
\hline
\end{tabular}

Table 2. Biomarkers found in the acidic. fractions of the original sample SP-7.

\begin{tabular}{|c|c|}
\hline \multicolumn{2}{|c|}{ SATURATED FRACTION } \\
\hline n-alkanes & $\begin{array}{c}\text { ranging from } C_{17} \text { to } C_{33} \text { with } \\
\text { an odd/even predominance. } R_{22}=6\end{array}$ \\
\hline Isoprenoids & $\begin{array}{c}\text { abundant } 2,6,10 \text {-trimethyl-7- } \\
\text { (methylbutyl)-dodecane. }\end{array}$ \\
\hline Hopenes & Hop-17(21)-enes \\
\hline Hopanes & from $C_{27}$ to $C_{31}$ \\
\hline Sterenes & $C_{27}, C_{23}$ and $C_{29}$ \\
\hline
\end{tabular}
Table 3. Bimarkers found in the saturate fraction of the original
sample Sp-7 


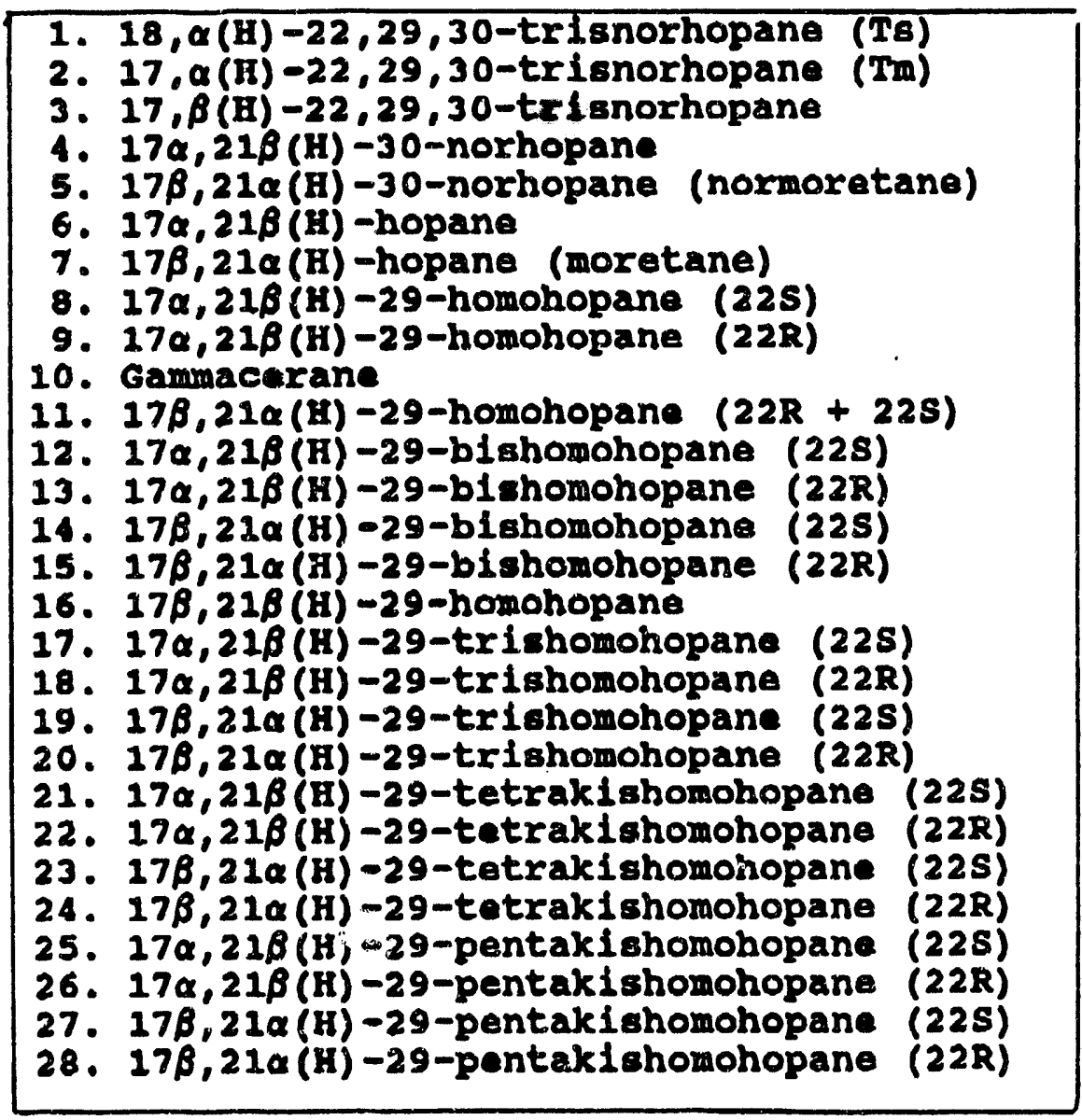

Table. 4. Tentative identification or hopanes, (Figure V.6), based on comparison of mass spectra and retention time with published data. 


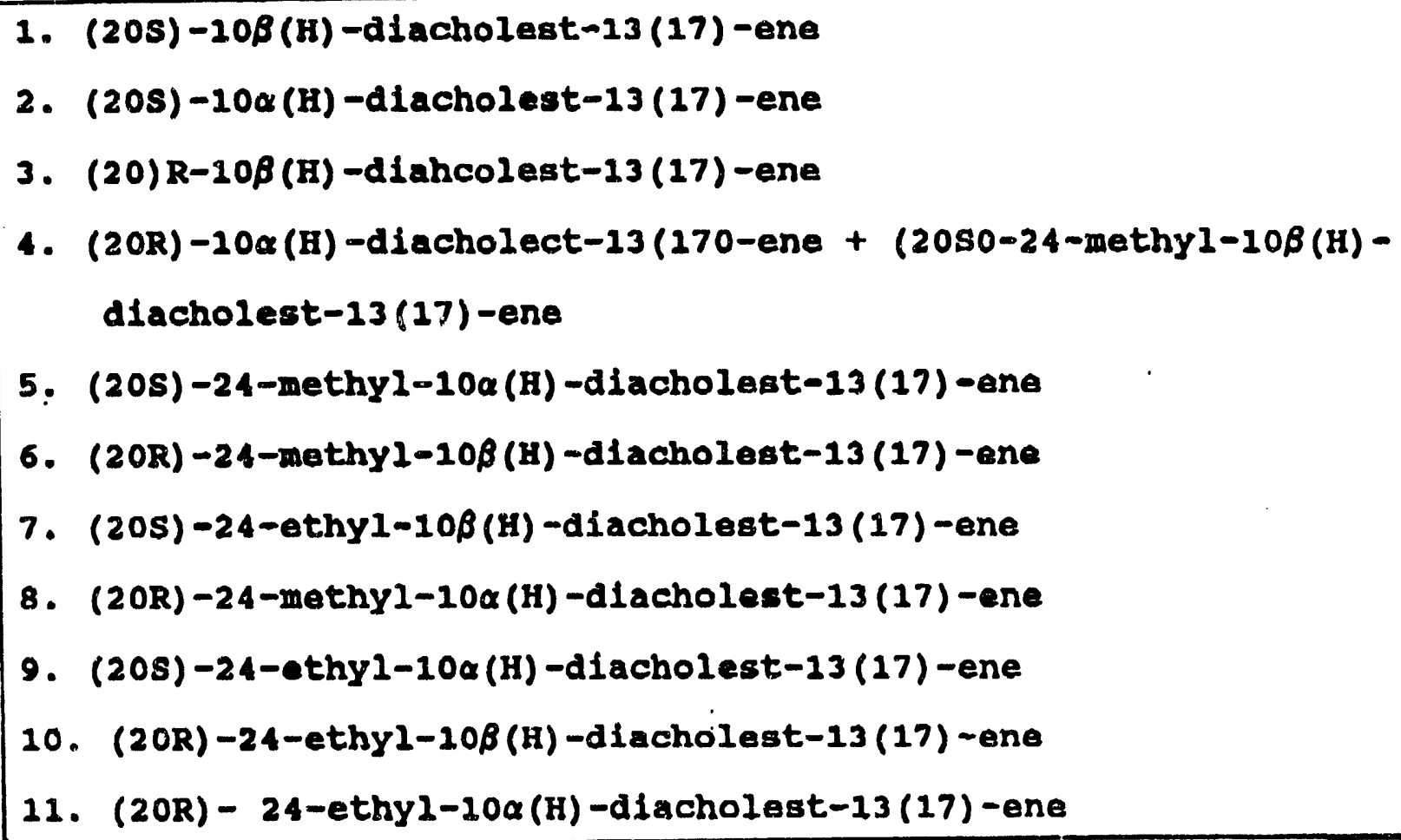

Table.5. Tentative identification of the diasterenes, (Figure v.7), based on comparison of mass spectra and retention time with published data. 
1. $5 \beta(H), 14 \alpha(H), 17 \alpha(H)$-cholestane

2. (2OR) $-5 \alpha(H), 17 \alpha(H)$-cholestane

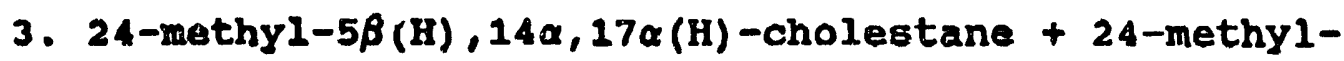
$5 \alpha(H), 14 \beta$ (H) , (17) $\beta$-cholestane

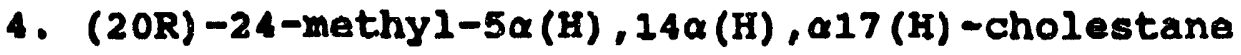

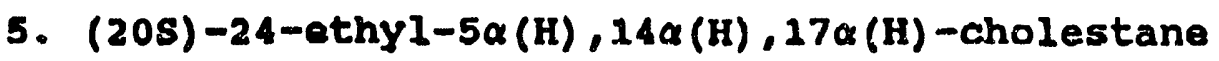

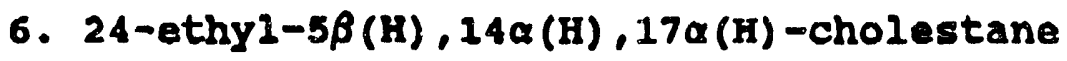

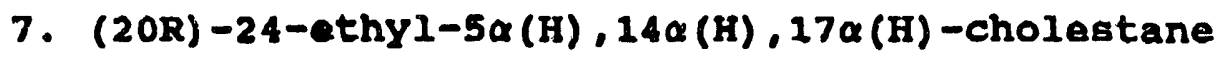

Table.6. Tentative identification of steranes, (Figure V.8), based on comparison of mass spectra and retention time with published data. 
1. $13 \beta, 17 \alpha$-dlacholestane (20s)

2. $13 \beta, 17 \alpha-d$ lacholestane (20R)

3. $13 \alpha, 17 \beta$-diacholestane (20S)

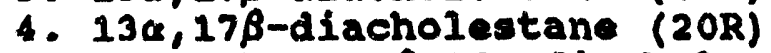

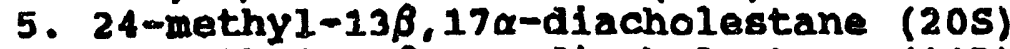

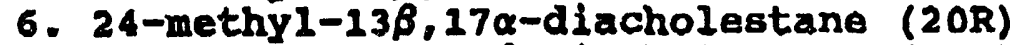

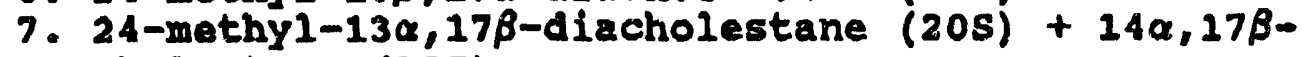
cholestane (205)

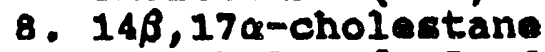

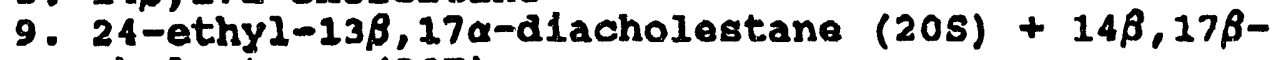
cholestane (2OR)

10. 24 -methy $1-13 \alpha, 17 \beta$-diacholestane $(20 R)+14 \beta, 17 \beta-$ cholestane (20S)

11. $14 \alpha, 17 \alpha$-cholestane (20R)

12. 24-ethyl-13 $\beta, 17 \alpha-a 1$ acholestane (2OR)

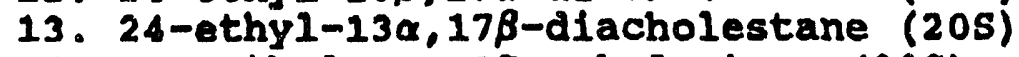

14. 24-methy $1-14 \alpha, 17 \alpha$-cholestane (20S)

15. 24-ethy $1-13 \alpha, 17 \beta$-alacholestane (20R) + 24-methyl$14 \beta, 17 \beta$-cholestane (20R)

16. 24-methyl-14 $\beta, 17 \beta$-cholestane (20S)

17. 24-methy1-14 $\alpha, 17 \alpha$-cholestane (20R)

18. 24-ethy $1-14 \alpha, 17 \alpha$-cholestane (20S)

19. 24-ethy1-14 $\beta, 17 \beta$-cholestane (20R)

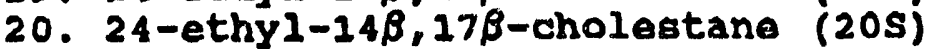

21. 24-ethy1-14 $\alpha, 17 \alpha$-cholestane (20R)

Table. 7. Tentative Identification of steranes and diasteranes, (Figure $v .9$ ), based on comparison of mass spectra and retention time with published data. 
$\infty$

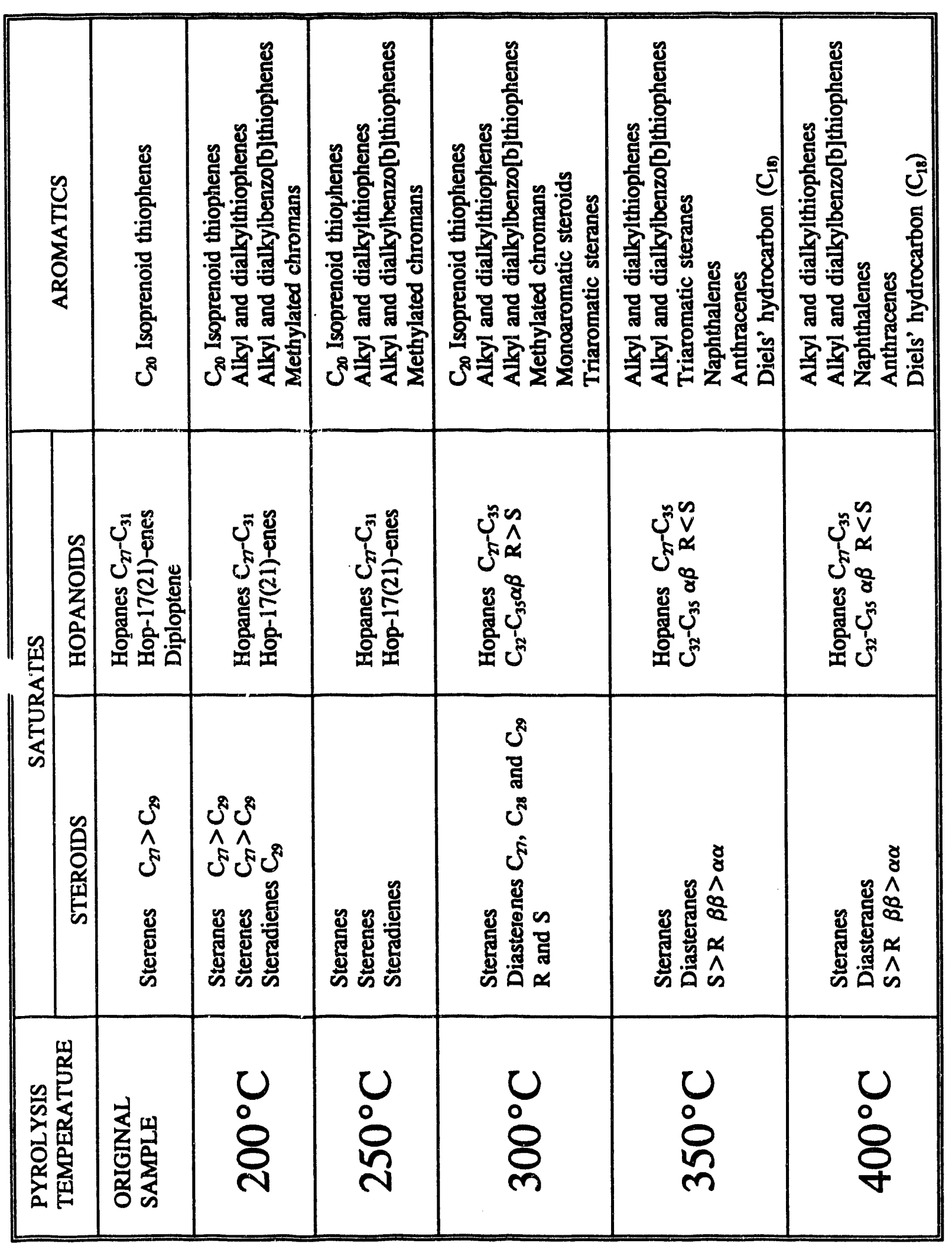

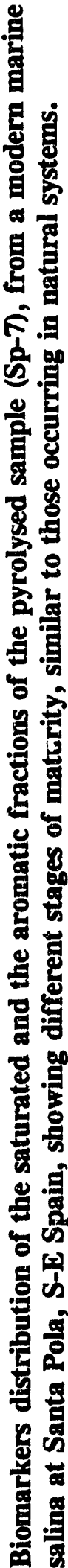




\begin{tabular}{|c|c|c|c|c|}
\hline \multirow{2}{*}{$\begin{array}{c}\text { BIOMARKERS } \\
\text { CHARACTERISTIC } \\
\text { OF } \\
\text { HYPERSALINITY }\end{array}$} & \multirow{2}{*}{$\begin{array}{c}\begin{array}{c}\text { MARINE } \\
\text { EVAPORITES }\end{array} \\
\begin{array}{c}\text { Salina at } \\
\text { Santa Pola }\end{array}\end{array}$} & \multirow{2}{*}{$\begin{array}{l}\begin{array}{l}\text { MARINE } \\
\text { SABKHA }\end{array} \\
\text { Al Quantir }\end{array}$} & \multicolumn{2}{|c|}{$\begin{array}{l}\text { LACUSTRINE } \\
\text { EVAPORITES }\end{array}$} \\
\hline & & & $\begin{array}{l}\text { Potrola } \\
\text { and } \\
\text { Saladar }\end{array}$ & $\begin{array}{l}\text { Quero } \\
\text { and } \\
\text { TIrez }\end{array}$ \\
\hline GAMMACERANE & Present & Present & Abundant & Pressent \\
\hline$C_{20}$ H.B.I.A. & Abundant & Present & \multicolumn{2}{|c|}{ Absent } \\
\hline $\begin{array}{c}\mathrm{C}_{20} \\
\text { ISOPRENOID } \\
\text { THIOPHENES } \\
\text { (I), } \\
\text { (II), and (III) }\end{array}$ & $\begin{array}{l}\text { (l) Is the most } \\
\text { abundant Isomer } \\
\text { with } \\
\text { Increasing maturity }\end{array}$ & $\begin{array}{l}\text { (I) is the most } \\
\text { abundant lsomer } \\
\text { with } \\
\text { increasing maturity }\end{array}$ & \multicolumn{2}{|c|}{$\begin{array}{l}\text { (l) Is the most } \\
\text { abundant lisomer } \\
\text { with } \\
\text { Increasing maturity }\end{array}$} \\
\hline \multirow{2}{*}{$\begin{array}{l}\text { METHYLATED } \\
\text { CHROMANS } \\
\text { (IV), (V), AND (VI) }\end{array}$} & $\begin{array}{l}\text { (IV) Is the most } \\
\text { abundant Isomer } \\
\text { In kerogen }\end{array}$ & $\begin{array}{l}\text { (IV) ls the most } \\
\text { abundant lsomer } \\
\text { In kerogen }\end{array}$ & \multicolumn{2}{|c|}{$\begin{array}{l}\text { (IV) ls the most } \\
\text { abundant lsomer } \\
\text { In kerogen }\end{array}$} \\
\hline & $\begin{array}{l}\text { (VI) Is the most } \\
\text { abundant lsomer } \\
\text { In total rock }\end{array}$ & $\begin{array}{l}\text { (VI) is the most } \\
\text { abundant lsomer } \\
\text { In total rock }\end{array}$ & \multicolumn{2}{|c|}{$\begin{array}{l}\text { (VI) ls the most } \\
\text { aburidant lsomer } \\
\text { In total rock }\end{array}$} \\
\hline
\end{tabular}

Table 6 . Biomarkers characteristic of hypersalinity found in the original and the matured samples from different evaporative environments. (I) : 2,3-dimethyl-5-(2,6,10- trimethylundecyl) thiphene; (II) : 3-methyl-2-(3,7,11-trimethyldodecyl) thiophene; (III) : 3-(4,8,12-trimethyltridecyl) thiophene; (IV) : 8-Me-MTTC; (V) : 7,8-diMe-MTTC; (VI) : 5,7,8-triMe-MTTC. 


\section{REFERENCES}

ALBAIGES, J. and TORRADIAS, J.M., 1974, Significance of the even carbon n-paraffin preference of a Spanish crude oil. Nature, v. 250, p. 567-568.

ALBAIGES, J., ALGABA, J., and GRIMALT, J., 1984, Extractable and sound neutral lipids in some lacustrine sediments. Organic Geochemistry, v. 6, p. 223-236.

BARBE, A., GRIMALT, J.O., PUEYO, J.Y., and ALBAIGES, J., 1990, Characterization of model evaporitic environments through the study of lipid components. in Advances in Organic Geochemistry, 1989. Organic Geochemistry v. 16, p. 815828.

BRASSELL, S.C., SHENG GUOYING, FU JIAMO, and EGLINTON, G. 1988, Biological markers in lacustrine Chinese oil shale. In Lacustrine Petroleum Source Rocks (A.J. Fleet, R., K. Kelts, and M. R. Talbot, eds.) Blackwell, p. 299-308.

BROOKS, J.O., GOULD, K., and SMITH, J.W., 1969, Isoprenoid hydrocarbons in Coal and Petroleum. Nature, v. 222, p. 257-259.

BUSSON, G., 1978, Couches laminées riches en matiere organique et precedant les roches salines: les enseignements d'un enchainement de faciès. Documents des laboratoires de. géologie Lyon, n 75, p. 5-18.

BUSSON, G., 1979, Couches laminées riches en matiere organique et precedant les roches salines: les enseignements d'un enchainement de faciès. Documents des laboratoires de. géologie Lyon, n 75, p. 5-18.

CONNAN, J., BOUROULLEC, J., DESSORT, D. and ALBRECHT, P., 1986, The microbial input into carbonate, anhydrite facies of a sabkha paleoenvironmental from Guatemala: A molecular approach. in Advances in Organic Geochemistry, 1985. Pergamon, Oxford, p. 29-50.

DE LEEUW, J.W. and SINNINGHE DAMSTE, J.S., 1990, Organic sulfur compounds and other biomarkers as indicators of paleosalinity. in Geochemistry of Sulfur in Fossil Fuels. American Chemical Society, Washington, D.C., p.417-443. 
DEWEY, J.F., HELMAN, M.L., TURCO, E., HUTTON, D.W.H. and KNOTT, S.D., 1989, Kinematics of the western Mediterranean. in Coward, M. P., Dietrich, D. and Park, R. G., eds., Alpine Tectonics. Geological Society Special Publication 45, p. 265283.

DIDYK, B.M., SIMONEIT, B.R.T., BRASSELL, S.C., and EGLINTON, G., 1978, Organic geochemical indicators of paleoenvironmental conditions of sedimentation. Nature, v. 272, p. 216-222.

DURAND, B. (ed) ,1980, Kerogen. Insoluble Organic Matter From Sedimentary Rocks. Editions Technip, Paris, 519 pp.

ESPITALIÉ, J., MADEC, M., TISSOT,B. and LEPLAT, P., 1977, Source rock characterization method for petroleum exploration. Offshore Technology Conference, OTC 2935, Houston. Texas, May, 2-5, 1977: p. 439-444.

EUGSTER, H.P., 1985, Oil shales, evaporites, and ore deposits. Geochimica et Cosmochimica Acta v. 49, p. 619-635.

EVANS, R., and KIRKLAND, D.W., 1988, Evaporitic environments as a source for petroleum. in Schreiber, B. C., ed., Evaporites and Hydrocarbons. Columbia University Press, New York, p. 256-299.

FREEMAN, K.H., 1989, Distinct origins of pristane and phytane: isotopic evidence. Geological Society America Abstracts with Programs v. 21, p. AlO.

FREEMAN, K.H., HAYES, J.M., TRENDEL, J.M,. and ALBRECHT, P., 1990, Evidence from carbon isotope measurements for diverse origins of sedimentary hydrocarbons. Nature, v. 343, p. 254-256.

FU JIAMO, SHENG GUOYING, and LIU LEHAN, 1988, Organic Geochemical characteristics of major types of terrestrial source rocks in China. In: Lacustrine Petroleum Source Rocks (A. J. Fleet, K. Kelts, and M. R. Talbot, eds.) Blackwell, p. 279-289.

FU JIAMO, SHENG GUOYING, PENG PINGAN, BRASSELL, S.C., EGLINTON, G., and JIGANG, J., 1986, Pecularities of salt lake sediments as potantial source rocks in China. Organic Geochemistry, v. 10, p. 119-126. 
FUKUSHIMA, K., YASUKAWA, M., MUTO, N., UEMURA, H. and ISHITAWARI, R., 1992, Formation of $\mathrm{C}_{20}$ isoprenoid thiophenes in modern sediments. Organic Geochemistry. v. 18, p. 83-91.

GEEL, T.,1976/1978, Messinian gypsiferous deposits of the Lorca basin (province of Murcia, SE Spain). Memorie Società Geologica Italiana, v.16, p. 369-385.

GOSSENS, H., DE LEEUW, J.W., SCHENCK, P.A., and BRASSELL, S.C., 1984, Tocopherols as likely precursors of pristane in ancient sediments and crude oils. Nature, v. 312, p. 440-442.

HILLS, I.R, WHITEHEAD, E.V., ANDERS, D.E., CUMMINS,J.J., and ROBINSON, W.E, 1966 An optically active triterpane, gammacerane in Green River, Colorardo, oil shale bitumine. Journal of the Chemical Society, Chemical Communications, v. 20, p. $752-754$.

HITE, R.J., and ANDERS, D.E., 1991, Petroleum and evaporites. in Melvin, J.L., ed., Evaporites, Petroleum and Mineral Resources, Elsevier, Amsterdam, p.349-411.

JAVOR, B., 1989, Hypersaline environments: Microbiology and Biogeochemistry. Springer-Verlag, Berlin. 328 pp.

JIANG, Z.S., and FOWLER, M.G., 1986, Cartenoid-derived alkanes in oils from northwestern China. Organic Geochemistry, v. 10, p. 831-839.

KENIG, F., HUC, A.Y., PURSER, B., and OUDIN, J-L., 1990, Sedimentation, distribution and diagenesis of organic matter in a recent carbonate enviornment, Abu Dhabi, U.A.E. in Advances in Organic Geochemistry, 1989. Organic Geochemistry, v. 16, p. 735-747.

KENIG, F., HUC, A.Y., PURSER, B.H. and OUDIN, J.L., 1990, Sedimentation, distribution and diagenesis of organic matter in arecent carbonate environment, Abu Dhabi, U.A.E. Organic Geochemistry, v 16, p. 735-747.

LEWAN, M.D., 1985, Evaluaton of petroleum generation by hydrous pyrolysis experimentation. Philosophical Transactions of the Royal Society of London, v. A 315, p. 123-134. 
MOLDOWAN, J.M., SUNDARARAMAN, P., and SCHOELL, M., 1986, Sensitivity of biomarker properties to depositional environment and/or source input in the Lower Toarcian of SW Germany. in Advances in Organic Geochemistry, 1985. Organic Geochemistry, v. 10, p. 915-926.

MOLDOWAN, J.M., SEIFERT, W.K., and GALLEGOS, E.J. (1985) Relationship between petroleum composition and depositional environment of petroleum source rocks. American Association of Petroleum Geologists Bulltein, v. 69, p. 1255-1268.

MONTHIOUX, M., LANDAIS, P. and DURAND, B.,1886, Comparison between extracts from natural and artificial maturation series of Mahakam delta coals. Organic Geochemistry, v. 10, p. 299-311.

MONTHIOUX, M., LANDAIS, P. and MONIN, G.C., 1985, Comparison beiween natural and artificial maturation series of humic coals from the Mahakam delta, Indonesia. Organic Geochemistry, v. 8, p. 275-292.

ORTI, F., 1990, Yesos di Lorca (Messinienese). in Orti Cabo, F. and Salvany Duran, J. $M^{a}$, eds., Formaciones evaporíticas de la Cuenca del Ebro y cadenas periféricas, y de la zona de levante. ENRESA, Departamente de Geoquimica Petrologia i Prospecció Geologia, Universidad Barcelona, p. 297-298.

PETERS,K.E. and MOLDOWAN, J.M., 1993, The Biomarker Guide Interpreting Molecular Fossils in Petroleum and Anclent Sediments. Prentice-Hall, Inc. a Simon \& Shuster Company Englewood Cliffs, New Jersey 07632. p. 363

PHILP, R.P., 1980, Studies of recent algal mats, coal shales and Precambrian sediments. in Prashnoushy, A., ed., Alfred Treibs Symposium, B.J.M. Universitat Wurzburg..p. 159-169.

PHILP, R.P., and LEWIS, C.A., 1987, Organic geochemistry of biomarkers. Annual Review Earth Planetary Sciences, v. 15, p. 363-395.

PHILP, R.P., BROWN, S., CALVIN, M., BRASSEL, S. and EGLINTON, G., 1978, Hydrocarbons and fatty acid distributions in recently deposited algal mats at Lajuna Guerrero; Baja California. in Krumbein, W.E., ed., Environmental Biogeochemistry and Geomicrobiology., Ann Arbor, Michigan, p. 255-270.. 
PIERRE, C., 1982 , Teneurs en isotopes stables $\left(\delta^{18} 0, \delta^{2} \mathrm{H}, \delta^{34} \mathrm{~S}\right)$ et conditions de genèse des évaporites marines: application à quelques milieux actuels et au Messinien de la Méditerranée. Thése de doctorat d'Etat, Univ. Paris-Sud, Centre Orsay, $222 \mathrm{pp}$.

POR, F. D., 1972, Hydrological notes on the high-salinity waters of the Sinai Peninsula. Marine Biology, v. 14, p. 11-119.

POWELL, T.G. and MCKIRDY, D.M., 1973, Relationship between ratio of pristane to phytane, crude oil composition and geological environment in Australia. Nature, v. 243, p. 37-39.

RISATTI, J.B., ROWLAND, S.J., YON, D.A., and MAXWELL, J.R., 1984, Stereochemical studies of acylic isoprenoids - XII. Lipids of methanogenic bacteria and possible distributions to sediments. in Advances in Organic Geochemistry, 1983. Organic Geochemistry, v. 6, p. 93-104.

ROBSON, J.N., and ROWLAND, S.J., 1986, Identification of novel widely distributed sedimentary acyclic sesterpanoids. Nature, v. 324, p. 561-563.

ROUCHY, J.M., 1982, La genese des evaporites messiniennes de Méditerranée. Memoire Museum Natural Histoire Paric (C), v.2, 267 pp.

ROWLAND, S.J., YON, D.A., LEWIS, C.A., and MAXWELL, J.R., 1985, Occurrence of 2,6,10-trimethyl-7-(B-methylbutyl)-dodecane and related hydrocarbons in the green alga Enteromorpha prolifera and sediments. in Organic Geochemistry, v. 8, 207-213.

SINNINGE DAMSTÉ, J.S., DE LEEUW, J.W., KOCK-VAN DALLEN, A.C., DE ZEEUW, M.A., DE LANGE, F., RIJPSTRA, W.I.C., and SCHENCK, P.A., 1987a, The occurrence and identification of series of organic sulfur compounds in oils and extracts. I. A study of Rozel Point oil (U.S.A.). Geochim. Cosmochem. Acta, v. 51, p. 2369-2391.

SINNINGE DAMSTÉ, J.S., KOCK-VAN DALLEN, A.C., DE LEEUW, J.W., SCHENCK, P.A., GUYOYINY, S. and BRASSELL, S.C., 1987b, The identification of mono-, di-, trimethyl 2-methyl-2-94,8,12-trimethyltridecyl chromans and their occurrence in the grosphere. Geochim. Cosmochim. Acta, v.51, p. 2393-2400. 
SINNINGH DAMSTÉ, J.S., RIJPSTRA, W.I.C., DE LEEUW, J.W., SCHENCK, P.A., 1989. The occurrence and identification of series of organic sulfur compounds in oils and sediment extracts. II. Their presence in samples from hypersaline and non-hypersaline paleoenvironments and possible applications as source, paleoenvironmental and maturity indicators. Geochim. Cosmochim. Acta, v.53, p. 1323-1341.

SINNINGH DAMSTÉ', J.S and DE LEEUW, J.W., 1990, Analysis, structure and geochemical signifacance of organlcally-bound sulfur in the geosphere: State of the art and future research. Organic Geochemistry, v. 16, p. 1077-1101.

SINNINGHE DAMSTÉ, J.S., DE LEEUW, J.W., KOCK-VAN DALLEN, A.C., DE ZEEUW, M.A., DE LANGE, F., RIJPSTRA W.I.C., and SCHENCK, P.A., 1987b, The occurence and identification of series of organic sulfur compounds in oils and extracts I. A Study of Rozel Point Oil (U.S.A.). Geochim. Cosmochim. Acta v.51, p. 2369-2391.

TEN HAVEN, H.L., DE LEEUW, J.W., and SCHENK, P.A, 1985, Organic geochemical studies of a messinian evpaorite basin, Northern Apennines (Italy). 1. Hydrocarbon biological markers for a hypersaline environment. Geochimica et Cosmochimica Acta, v. 49, p. 2181-2191.

TEN HAVEN, H.L., DE LEEUW, J.W., RULLKOTTER, J., and SINNINGHE DAMSTÉ, J.S., 1987, Restricted utility of the pristane/phytane ratio as a palaeoenvironmental indicator. Nature, v. 330, p. $641-643$

TEN HAVEN, H.L., DE LEEUW, J.W., SINNINGHE DAMSTE, J.S., SCHENK, P.A., PALMER, S.E. and ZUMBERGE, J.E., 1988, Application of biological markers in the recognition of paleohypersaline environments. in Fleet, A.J.U., Kelts, K. and Talbot, M.R., eds., Lacustrine Petroleum Source Rocks, Geological Society Publication, n. 40, p. 123-130.

TEN HAVEN, H.L., ROHMER, M., RULLKOTTER, J., and BISSERET, P., 1989, Tetrahymanol, the most likely precursor of gammacerane, occurs ubiquitously in marine sediments. Geochim. Cosmochim. Acta v.53, p. 3703-3709.

TISSOT, J.B. and WELTE, D.H., 1984, Petroleum Formation and Occurrence (2nd ed.), Springer Verlag, Berlin, 538 pp. 
UTRILLA, R., 1989 , Les composicions isotópiques $\left(\delta^{180}, \delta^{34} \mathrm{~S}\right)$ del sulfat, com a indicadores de l'origen de les evaporites del Mesozoic i del Cenozoic de la Peninsula Ibèrica i les Illes Balears. Tesis Doctoral, Facultad de Geología, Universidad de Barcelona, 276 pp.

VEIGAS, J.G., ROSELL, L., UTRILLA, R. and ORTI, F.,1990, Aportaciones geoquimicas al conocimiento de las evaporitas messinienes: cuencas de Palma (Mallorca), San Miguel de Sallnas (Alicante) y Lorca (Murcia). in Orti Cabo, F., and Salvany Duran, J. Ma., eds., Formaciones evaporíticas de la Cuenca del Ebro y cadenas periféricas, $\theta$ de zona de Levante. ENRESA, Universidad de Barcelona, p. 257266.

VENKATSEAN, M.I., 1989, Tetrahymanol: Its widespread occurrence and geochemical slgnlficance. Geochimica et Cosmochimica Acta, v. 53, p. 3095-3101.

VOLKMAN, J.K. and MAXWELL, J.R., 1986, Acyclic isoprenoids as biological markers. in Johns, R.B., ed., Biological Markers in the Sedimentary Record. Amsterdam, Elsevier, p. 1-42.

VOLKMAN, J.K., ALLEN, D.I., PHILIP, L.S. and BURTON, H.R., 1986, Bacterial and algal hydrocarbons in sediments from a saline Antarotic lake. Ace Lake. in Advances in Organic Geochemistry, 1985. Organic Geochemistry, v. 10, p. 671 681.

WAKEHAM, S.G. and CANVEL, E.A., 1990, Fatty acids and sterols of particulate matter in brackish and seasonally anoxic coastal salt pond. in Advances in Organic Geochemistry, 1989. Organic Geochemistry, v. 16, p. 703-713.

WAPLES, D.W., HAUG, P. and WELTE, D.H., 1974, Occurrences of a regular $C_{25}$ isoprenoid hydrocarbon in Tertiary sediments representing a lagoonal, saline environment. Geochimica et Cosmochimica Acta, v.38, p. 381-387.

WARREN, J.K., 1986, Shallow-water evaporitic environments and their source-rock potential. Journal Sedimentary Petrology, v. 56, p. 442--454.

YON, D.A., MAXWELL, J.R., and RYBACH, G., 1982, 2,6,10-trimethyl-7-(3-methylbutyl)dodecane, a novel sedimentary biological marker compound. Tetrahedron Letters, v. 23, p. 2143-2146. 

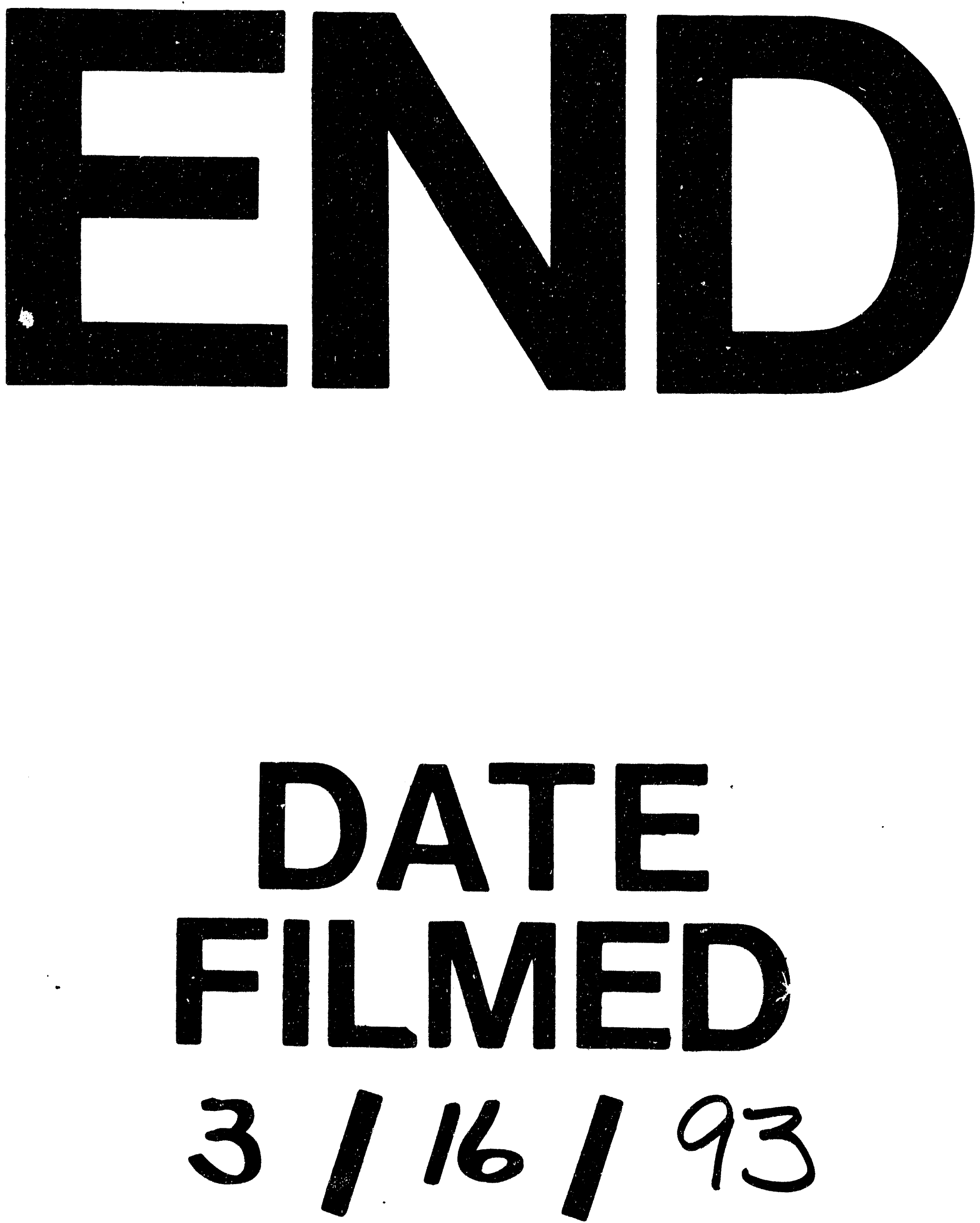
